\title{
MAPEAMENTO DAS ÁREAS DE RISCO DE EROSÃO DOS SOLOS DA BACIA DO RIO PIRACICABA, UTILIZANDO GEOPROCESSAMENTO
}

\section{CARLOS EDUARDO PELLEGRINO CERRI}

Engenheiro Agrônomo

Orientador: Prof. Dr. JOSÉ ALEXANDRE MELO DEMATTÊ

Dissertação apresentada à Escola Superior de Agricultura "Luiz de Queiroz", Universidade de São Paulo, para obtenção do título de Mestre em Agronomia, Área de Concentração: Solos e Nutrição de Plantas.

P I R A C I C A B A

Estado de São Paulo - Brasil

Junho - 1999 
Dados Internacionais de Catalogação na Publicação (CIP)

DIVISĀo DE BIBLIOTECA E DOCUMENTAÇĀo - Campus "Luiz de Queiroz"/USP

\section{Cerri, Carlos Eduardo Pellegrino}

Mapeamento das áreas de risco de erosão dos solos da bacia do rio Piracicaba, utilizando geoprocessamento / Carlos Eduardo Pellegrino Cerri. - - Piracicaba, 1999. 89 p.

Dissertaçāo (mestrado) - - Escola Superior de Agricultura Luiz de Queiroz, 1999. Bibliografia.

1. Bacia do Rio Piracicaba 2. Erosão 3. Geoprocessamento 4. Mapeamento 5. SIG 6. Solo I. Titulo

CDD 631.45

551.302 
Aos meus pais Carlos e Ana, avó Biloca e irmão Gui, pela minha formação acadêmica e pessoal dedico

À minha esposa Alessandra, com muito amor

ofereço 


\section{AGRADECIMENTOS}

Agradeço à Deus, pela vida maravilhosa

Ao Prof. Dr. José Alexandre Melo Demattê, pela orientação geral e amizade.

À Dra. Maria Victória Ramos Ballester pelos valiosos ensinamentos que me proporcionou, pelo incentivo em todos os momentos e amizade.

Aos Dr. Luiz Antonio Martinelli e Dr. Reynaldo Luiz Victória pelo apoio e amizade.

Ao Dr. Eric Roose, Orstom-Montpell ier-França, pela orientação das atividades de campo.

Aos Dr. Christian Feller e Dr. Vincent Eschembrenner, pelo acompanhamento das atividades de campo e valiosas sugestões.

Aos Dr. Francisco Lombardi Neto do IAC e Dr. Antonio Roberto Formaggio do INPE, pelas valiosas críticas e sugestões.

Ao Prof. Dr. Gerd Sparovek, pelas informações e esclarecimentos prestados durante a execução do trabalho.

À ESALQ/USP pela oportunidade concedida.

Ao Centro de Energia Nuclear na Agricultura, pelas facilidades de pesquisa.

Ao Projeto Piracena, do CENA, pelo apoio logístico oferecido.

À ESSO, FAPESP, CNPq/PADCT, pelo financiamento deste trabalho.

À CAPES e FAPESP, pelas bolsas de estudo concedidas.

Aos amigos André, Andrea, Daniel, Solange, Wesley, Neusa, Patrícia e colegas da Pósgraduação, pela amizade e colaboração.

A todos aqueles que, de alguma forma, contribuíram para a realização deste trabalho, muito obrigado. 


\section{SUMÁRIO}

Página

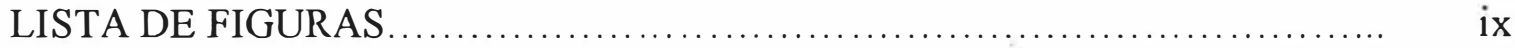

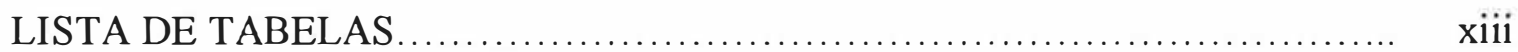

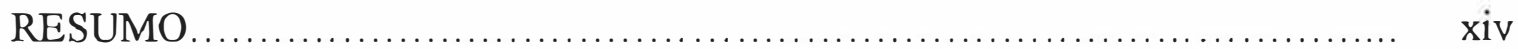

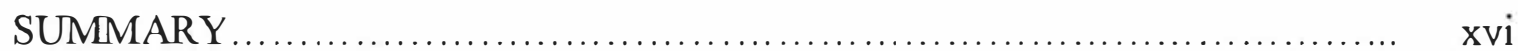

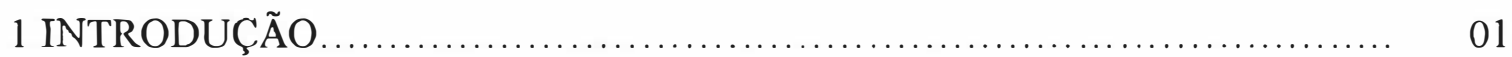

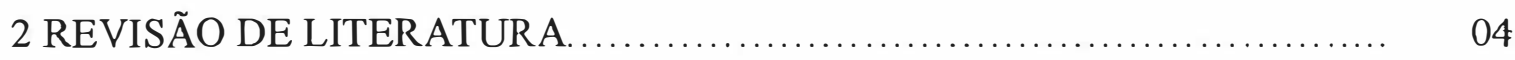

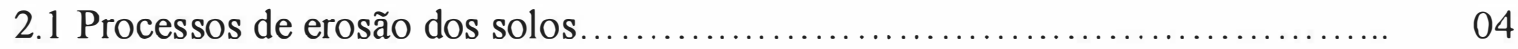

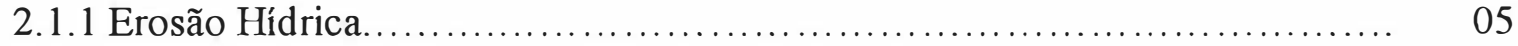

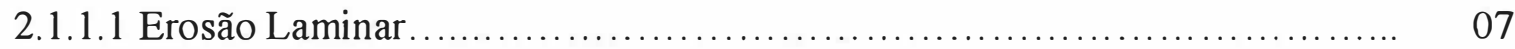

2.1.1.2 Erosão Linear..................................................... 08

2.2 Equação Universal de Perda de Solo (EUPS) ........................... 11

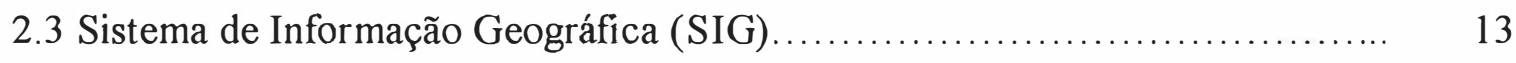

2.3.1 Breve histórico.................................................. 14

2.3.2 Conceitos e definições.............................................. 15

2.4 Exemplos de utilização de SIG em estudos de erosão ....................... 17 


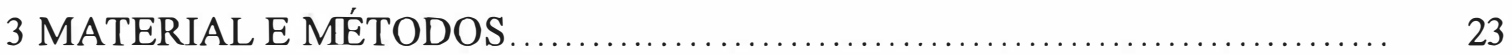

3.1 Caracterização da área de estudo ........................................ 23

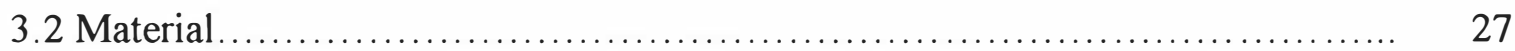

3.2.1 Banco de dados................................................ 27

3.2 .2 Equipamentos................................................ 28

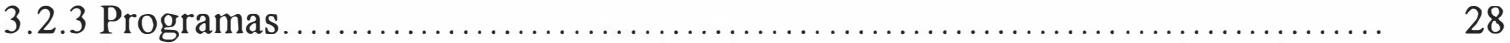

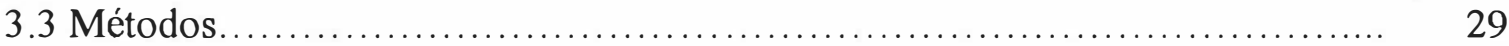

3.3.1 Obtenção dos fatores da Equação Universal de Perda de Solo................ 31

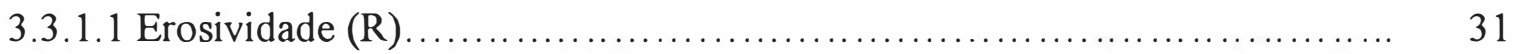

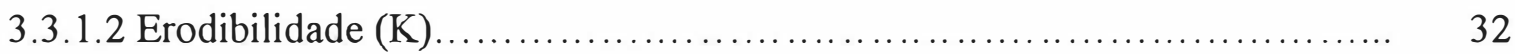

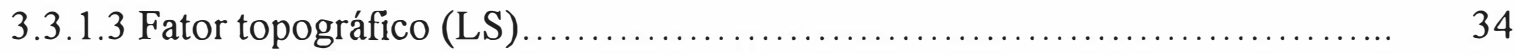

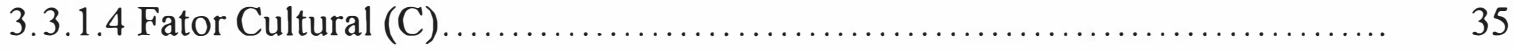

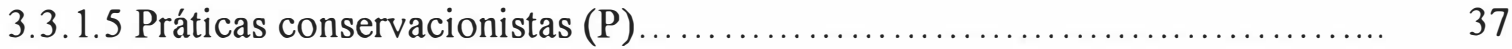

3.3.2 Verificação no campo do mapa de risco de erosão ...................... 37

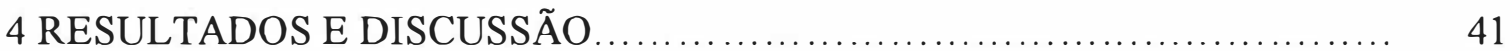

4.1 Bases necessárias para o mapeamento do risco de erosão.................... 41

4.1.1 Mapa de Solos e valores de erodibilidade calculados para os solos da bacia do rio Piracicaba 
4.1.1.1 Mapa de solos da bacia....................................... 41

4.1.1.2 Valores de erodibilidade calculados para os solos da bacia do Piracicaba... 43

4.1.2 Mapa de Uso e Cobertura do Solo para os anos de 1978 e $1993 \ldots \ldots \ldots \ldots \ldots . . . . .45$

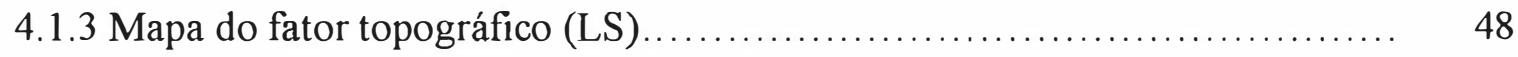

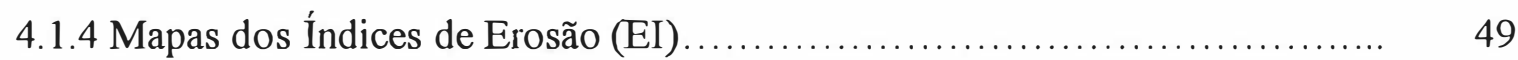

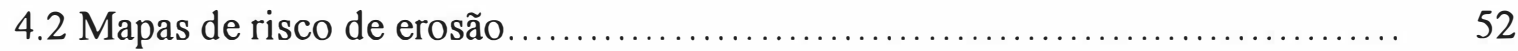

4.2.1 Mapas de risco de erosão para o ano de $1978 \ldots \ldots \ldots \ldots \ldots \ldots \ldots \ldots \ldots \ldots \ldots \ldots \ldots \ldots \ldots \ldots \ldots$

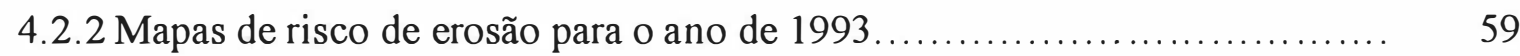

4.2.3 Comparação entre os mapas de risco de erosão dos solos da bacia do rio Piracicaba para os meses de janeiro e julho de 1978 e $1993 \ldots \ldots \ldots \ldots \ldots \ldots . . \ldots 3$

4.3 Verificação no campo do mapa de risco de erosão para o mês de janeiro de 1993 com prática de plantio em contorno............................... 66

4.3.1 Caracterização geral da bacia para fins de estimativa do risco de erosão..... 66

4.3.2 Estimativa dos riscos de erosão a partir dos sedimentos dos rios............. 67

4.3.3 Risco de erosão observado em diferentes usos da terra.................... 69

4.3.3.1 Cana-de-açúcar................................................ 69

4.3.3.2 Vegetação florestal........................................... 70

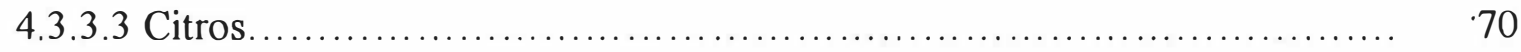

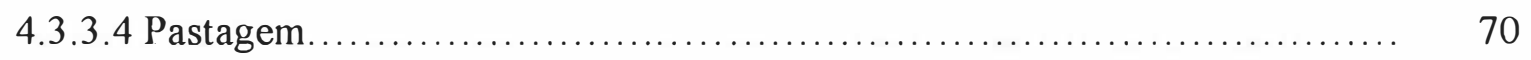


4.3.4 Comparação entre o risco de erosão obtido pelo mapa e o observado no campo

4.3.5 Limitaçõoes da verificação no campo do mapa de risco de erosão.

5 CONCLUSÕES

REFERÊNCIAS BIBLIOGRÁFICAS. 


\section{LISTA DE FIGURAS}

\section{Página}

1 Diagrama de relações entre a demolição de agregados, crostas de deposição e erosão, adaptado de Le Bissonnais (1996)

2 Localização da bacia do rio Piracicaba

3 Principais rios da bacia

4 Mapa geológico da bacia do rio Piracicaba, segundo São Paulo (1991a)....

5 Características climáticas da bacia do rio Piracicaba.

6 Fluxograma da metodologia utilizada para a obtenção dos mapas de risco de erosão.

7 Mapa de solos da bacia do rio Piracicaba

8 Distribuição das frequências das unidades de mapeamento dos solos da bacia do rio Piracicaba.

9 Mapa de uso e cobertura do solo do ano 1978.

10 Mapa de uso e cobertura do solo em 1993

11 Porcentagem da área coberta para cada tipo de uso da terra nos anos de 1978 e 1993.

12 Mapa do fator topográfico da bacia do rio Piracicaba

13 Mapa dos índices de erosão da bacia do rio Piracicaba em janeiro de $1978 \ldots . .$. 
14 Mapa dos índices de erosão da bacia do rio Piracicaba em julho de $1978 \ldots . . . .$.

15 Mapa dos índices de erosão da bacia do rio Piracicaba em janeiro de $1993 \ldots \ldots . .$.

16 Mapa dos índices de erosão da bacia do rio Piracicaba em julho de 1993

17 Mapa de risco de erosão da bacia do rio Piracicaba em janeiro de 1978, com prática de plantio em contorno

18 Mapa de risco de erosão da bacia do rio Piracicaba em janeiro de 1978, com prática de plantio morro abaixo.

19 Mapa de risco de erosão da bacia do rio Piracicaba em julho de 1978, com prática de plantio em contorno

20 Mapa de risco de erosão da bacia do rio Piracicaba em julho de 1978, com prática de plantio morro abaixo

21 Mapas de risco de erosão da bacia do rio Piracicaba, para o ano de 1978: a) janeiro com plantio morro abaixo; b) janeiro com plantio em contorno; c) julho com plantio morro abaixo; d) julho com plantio em contorno; e) simulação com substituição da pastagem por cana-de-açúcar; f) simulação com substituição da pastagem por silvicultura e g) simulação com substituição da pastagem por vegetação nativa. 
22 Detalhes dos mapas de risco de erosão da bacia do rio Piracicaba, para o ano de 1978, apresentados na Figura 21: a) janeiro com plantio morro abaixo; b) janeiro com plantio em contorno; c) julho com plantio morro abaixo; d) julho com plantio em contorno; e) simulação com substituição da pastagem por cana-de-açúcar; f) simulação com substituição da pastagem por silvicultura e g) simulação com substituição da pastagem por vegetação nativa.

23 Mapa esquemático das áreas com risco de erosão elevado na bacia do rio Piracicaba, para o ano de 1978

24 Mapa de risco de erosão da bacia do rio Piracicaba em janeiro de 1993, com prática de plantio em contorno.

25 Mapa de risco de erosão da bacia do rio Piracicaba em janeiro de 1993, com prática de plantio morro abaixo.

26 Mapa de risco de erosão da bacia do rio Piracicaba em julho de 1993, com prática de plantio em contorno.

27 Mapa de risco de erosão da bacia do rio Piracicaba em julho de 1993, com prática de plantio morro abaixo

28 Mapa esquemático das áreas com risco de erosão elevado na bacia do rio Piracicaba, para o ano de 1993

29 Distribuição percentual das áreas de risco baixo de erosão, com prática morro abaixo, para os anos de 1978 e 1993: efeito da chuva.

30 Distribuição percentual das áreas de risco baixo de erosão, para o mês de janeiro dos anos de 1978 e 1993: efeito das práticas conservacionistas. 
31 Distribuição percentual das áreas de risco baixo de erosão: pior situação de

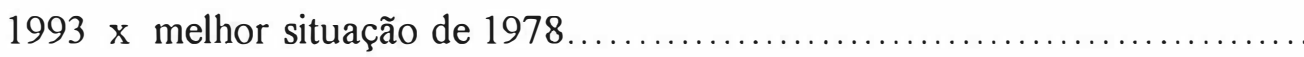

32 Mapa de risco de erosão dos solos da bacia do rio Piracicaba, para o mês de janeiro de 1993, com prática de plantio em contorno e os pontos de

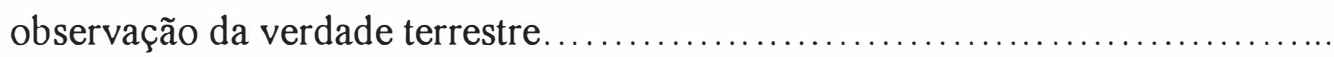




\section{LISTA DE TABELAS}

Página

1 Diâmetro médio de cada classe textural para o cálculo do diâmetro médio ponderado das partículas.

2 Valores de $\mathrm{C}$ correspondentes às diferentes categorias de uso e cobertura do solo observadas na bacia do rio Piracicaba.

3 Valores de erodibilidade para os solos da bacia do rio Piracicaba....

4 Distribuição percentual das áreas de risco de erosão na bacia do rio Piracicaba, para os meses de janeiro e julho de 1978 com práticas de plantio morro abaixo e em contorno

5 Distribuição percentual das áreas de risco de erosão na bacia do rio Piracicaba, para os diferentes usos e coberturas do solo, para o mês de janeiro de $1978 \mathrm{com}$ prática de plantio em contorno.

6 Distribuição percentual das áreas de risco de erosão na bacia do rio Piracicaba, para os meses de janeiro e julho de 1993 com práticas de plantio morro abaixo e em contorno.

7 Comparação entre os riscos de erosão obtidos do mapa (gerado através do geoprocessamento) e os riscos observados no campo 


\title{
MAPEAMENTO DAS ÁREAS DE RISCO DE EROSÃO DOS SOLOS DA
}

\author{
BACIA DO RIO PIRACICABA, UTILIZANDO
}

GEOPROCESSAMENTO

\author{
Autor: CARLOS EDUARDO PELLEGRINO CERRI \\ Orientador: Prof. Dr. JOSÉ ALEXANDRE MELO DEMATTÊ
}

\section{RESUMO}

Os recursos naturais tais como a vegetação, a água e o solo, vêm sendo submetidos a uma progressiva pressão. A erosão, sobretudo na forma hídrica, ocorre na maioria dos Estados, e também na bacia do rio Piracicaba, uma das regiões mais desenvolvidas do país, situada no centro oeste do Estado de São Paulo. Uma das formas mais eficientes para fornecer subsídios à seleção de áreas prioritárias do ponto de vista de conservação e recuperação do solo, é a utilização de mapas de risco de erosão. O propósito destes mapas é mostrar a expectativa de perda de solos sob sistemas de ocupação da terra alternativos. Esses mapas podem auxiliar na tomada de decisão, para que se possa readquirir a qualidade ambiental desejável. O objetivo deste estudo foi mapear as áreas de risco de erosão dos solos da bacia do rio Piracicaba, para os meses de janeiro e julho dos anos de 1978 e 1993, através da utilização de técnicas de geoprocessamento e comparar a evolução do processo erosivo dos solos neste período. Para tal, adotou-se a Equação Universal de Perdas de Solos (EUPS), um modelo matemático empírico para a predicção de perdas de solo por erosão laminar e linear. Em função da extensão da bacia, da diversidade de solos e complexidade do uso da terra, os parâmetros da EUPS foram espacializados, processados e analisados usando um Sistema de Informações Geográfica (SIG). Foram gerados mapas de risco de erosão dos solos da bacia para janeiro e julho dos anos de 1978 e 1993, com duas práticas de manejo: plantio em contorno e plantio morro abaixo. Os valores estimados de perdas de solo por erosão foram agrupados em quatro classes de risco: baixo $\left(0-2 \mathrm{t} \mathrm{ha}^{-1}\right)$, médio $\left(2-4 \mathrm{tha}^{-1}\right)$, alto $\left(4-6 \mathrm{t} \mathrm{ha}^{-1}\right)$ e muito alto $\left(>6 \mathrm{t} \mathrm{ha}^{-1}\right)$. Os resultados 
mostraram que esta bacia hidrográfica, de uma maneira geral, possui um risco baixo de erosão. As áreas com risco de erosão mais acentuado estão localizadas principalmente em duas regiões: ao redor do eixo de maior desenvolvimento urbano (entre as cidades de Piracicaba e Campinas) e próxima às nascentes dos rios que compõem a bacia. Na primeira região mencionada, o maior risco se deve, provavelmente, à exposição de solos de textura predominantemente arenosa às chuvas, especialmente sob o cultivo da cana-de-açúcar. As causas do risco de erosão elevado, na área próxima às nascentes, estão relacionadas à interação dos agentes: relevo acidentado, solos pouco profundos, pastagem mal manejada (algumas vezes degradadas) e pluviosidade elevada. O mapa de risco de erosão dos solos para o mês de janeiro com prática de plantio em contorno foi verificado no campo (verdade de terreno), obtendo-se um valor aproximado de $80 \%$ de correspondência entre as estimativas dos riscos de erosão obtidas pelo mapeamento e pela observação de campo. Esses resultados indicaram que a aplicação da EUPS através da utilização de técnicas de geoprocessamento, é uma metodologia adequada e pode ser considerada como uma ferramenta importante para o diagnóstico e monitoramento de áreas de risco de erosão. 


\title{
MAPPING SOIL EROSION RISK AREAS IN THE PIRACICABA RIVER
}

\section{BASIN, USING GEOPROCESSING}

\author{
Author: CARLOS EDUARDO PELLEGRINO CERRI \\ Adviser: Prof. Dr. JOSÉ ALEXANDRE MELO DEMATTÊ
}

\section{SUMMARY}

The natural resources such as vegetation, water and soil, are being submitted to a progressive pressure. The erosion, manly the water erosion, is occurring in most of States, and also in the Piracicaba river basin, one of the most developed areas in the country, placed at the Center West of the São Paulo State. One of the most efficient ways to supply subsidies in order to select priorities areas in terms of soil conservation and rehabilitation, is the use of erosion risk maps. The purpose of these maps is to show the expectation of soil loss under alternative systems of land use/land cover. Those maps can aid the decision making, helping to reacquire the desirable environmental quality. The objective of this study was to map soil erosion risk areas in the Piracicaba river basin, for January and July of 1978 and 1993, through the utilization of geoprocessing techniques and to compare the evolution of the soil erosion process in this period. To achieve this study, the Universal Soil Loss Equation (USLE) was adopted, an empiric mathematical model used to predict soil losses by sheet and rill erosion. Because of the basin extension, soil diversity and land use/land cover complexity, the parameters of USLE were created, processed and analyzed using a Geographical Information System (GIS). Maps of soil erosion risk were generated for January and July of 1978 and 1993, with two conservation practices: contouring practices and down hill cultivation. The estimated values of soil losses were grouped in four risk classes: low $\left(0-2 t \mathrm{th}^{-1}\right)$, medium $(2-4 \mathrm{t}$ ha ${ }^{1}$ ), high $\left(4-6 t^{-1} a^{-1}\right)$ and very high $\left(>6 t h^{-1}\right)$. The results showed that the basin in general has a low erosion risk. The area with highest erosion risk are mainly located in two regions: towards the Eastern and Western ends of the basin. In the East side, the highest erosion risk was observed in 
areas where there are presence of steep slopes, occurrence of shallow soils, high intensity of rainfall and pasture badly managed (sometimes degraded). In the West side the highest risk areas were those where sandy soils predominates under sugar-cane cultivation. The soil erosion risk map for January with contouring practices was verified in the field (earth truth), being obtained a value of approximately $80 \%$ of correspondence between the estimation of the erosion risks obtained by the map and for the field observation. Those results indicated that the application of USLE, through geoprocessing techniques, is an appropriate methodology and it can be considered as an important tool for the diagnosis and monitoring of erosion risk areas. 


\section{INTRODUÇÃO}

No Brasil, assim como na América Latina, a população duplicou nestes últimos 30 anos. Como resultado desse vertiginoso crescimento demográfico, os recursos naturais tais como a vegetação, a água e o solo, vêm sendo submetidos a uma progressiva pressão. A erosão, sobretudo na forma hídrica, ocorre na maioria dos Estados, como por exemplo, no Rio Grande do Sul que perde em média 240 milhões de toneladas de solo por ano (FAO, 1992).

As práticas agrícolas inadequadas, com excessivas arações e gradagens do solo, tornaram as terras expostas ao arraste pelas chuvas torrenciais de verão, causando assoreamento de barragens e a deposição dos sedimentos, interferindo na navegabilidade dos rios.

Estima-se que cerca de 80 \% da área cultivada do Estado de São Paulo esteja sofrendo processo erosivo além dos limites de tolerância. Este processo acarreta perdas estimadas em 194 milhões de toneladas de solo por ano, das quais 48,5 milhões de toneladas/ano atingem os mananciais em forma de sedimentos transportados, causando assoreamento e poluição desses recursos (Bertoni \& Lombardi Neto, 1990). As terras erodidas contém quantidades apreciáveis de nutrientes, matéria orgânica, sementes e defensivos, que além de causar a poluição dos corpos d'água, tendem ainda a aumentar a médio e longo prazos os custos de produção (Lal, 1999).

Esse processo, também ocorre na bacia do rio Piracicaba, uma das regiões mais desenvolvidas do país, situada no centro oeste do Estado de São Paulo. Originalmente, a bacia era coberta principalmente por floresta subtropical semidecídua e áreas menores com cerrado. O início da ocupação intensiva da terra, ocorreu no começo deste século, com o cultivo de café e culturas de subsistência. Posteriormente, o café foi substituído 
por pastagens e, mais recentemente parte foi transformado em cultivos de cana-deaçúcar, citros e reflorestamentos com eucalipto (FUNDAP, 1991). Essas culturas, ao contrário das pastagens, necessitam de um elevado manejo. O uso intensivo de insumos agrícolas e maquinário pesado em solos tropicais, muitas vezes frágeis, acarreta degradação dos solos e alteração do ambiente.

Estudos preliminares (CETESB, 1991; IPT, 1991; São Paulo, 1994) evidenciaram que a região da bacia do rio Piracicaba está sendo afetada por processos erosivos, manejo inadequado de áreas de mineração, disposição inapropriada de resíduos poluentes, desmatamento acentuado e irregular de áreas de proteção ambiental, entre outros. Esses processos de degradação certamente influenciam a qualidade e quantidade da água da bacia, a qual é utilizada para consumo doméstico e industrial.

É portanto, imprescindível neste momento, propor ações dirigidas para inicialmente reconhecer e caracterizar as áreas degradadas, para que posteriormente, essas áreas possam ser recuperadas. Ao mesmo tempo, deve-se buscar a sustentabilidade, desenvolvendo práticas que conservem os recursos, evitem a erosão do solo e que contribuam para aumentar a produção e diminuir os custos operacionais.

Uma das formas mais eficientes para fornecer subssídio à seleção de áreas prioritárias do ponto de vista de conservação e recuperação do solo, é a utilização de mapas de risco de erosão.

O risco de erosão pode ser entendido como a probabilidade de desencadeamento da erosão acelerada em futuro próximo (Bergsma, 1983). O propósito dos mapas de risco de erosão é mostrar a expectativa de perda de solos sob sistemas de ocupação da terra alternativos. Esses mapas podem ser atualmente obtidos de maneira mais rápida e eficiente, graças ao aparecimento de novas ferramentas, tais como Sistemas de Informações Geográficas e sensoriamento remoto integrados ao manejo dos recursos em nível de bacia ou microbacia hidrográfica. Essas informações podem auxiliar na tomada de decisão pelos órgãos relacionados ao planejamento, conservação dos solos e da qualidade das águas para que se possa readquirir a qualidade ambiental desejável. 
Portanto, o objetivo da presente pesquisa foi mapear as áreas de risco de erosão dos solos da bacia do rio Piracicaba, através da utilização do geoprocessamento. Para tanto, foram elaborados mapas de risco de erosão dos solos da bacia, para os anos de 1978 e 1993, comparando-se a evolução do processo erosivo no mesmo período. 


\section{REVISÃO DE LITERATURA}

A presente revisão bibliográfica está dividida, basicamente, em quatro grandes partes. A primeira (2.1) abordará, de maneira geral, os processos de erosão dos solos. A segunda parte (2.2), tratará da Equação Universal de Perda de Solo (EUPS). Na terceira parte (2.3), serão abordados conceitos e definições de Sistema de Informação Geográfica (SIG). Na última parte (2.4), serão apresentados exemplos de utilização de SIG em estudos de erosão.

\subsection{Processos de erosão dos solos}

Nenhum outro processo que ocorre no solo é mais destrutivo do que a erosão. A erosão é um processo de desprendimento e arraste acelerado das partículas do solo, que abrange perdas de água e de nutrientes vegetais em ritmos muito elevados (Lal, 1988; Roose, 1994). O mais trágico, é que poderá resultar na perda total do solo, sendo removido e deslocando-se para os cursos d'água, transformando-se em um problema de poluição (Prandini \& Nakazawa, 1995; Kertzman et al., 1995; Roose, 1998).

A erosão pode ser causada pelo vento (erosão eólica) ou pela água (erosão hídrica). A erosão eólica, ocorre mais comumente em regiões áridas e semi-áridas, podendo, entretanto, com menor freqüência, ocorrer em regiões de climas úmidos. Todos os solos e seus componentes sofrem influências; por vezes suas porções mais finas são carreadas a grande altura e por centenas de quilômetros de distância (Brady, 1989). Em regiões tropicais, a erosão hídrica é a forma que possue maior importância e, por se tratar do tema central desta pesquisa, será abordada de maneira mais aprofundada. 


\subsubsection{Erosão Hídrica}

O início desse fenômeno se dá pelo desprendimento das partículas do solo, através de dois mecanismos: impacto das gotas de chuva na superficie do terreno e pelo escoamento superficial (Queiroz Neto \& Christofoletti, 1968). O primeiro mecanismo, que corresponde ao movimento das partículas em diversas direções, denominado de saltitação, "splash erosion" ou salpico, é responsável pela preparação das partículas para o seu transporte. Segundo Fournier (1975), este é o mecanismo de formação dos elementos susceptíveis ao arrasto pela água. No segundo mecanismo, as partículas, desprendidas pela ação hidráulica do escoamento superficial (“runoff”) encontram-se de imediato sujeitas ao transporte. Nos dois mecanismos há um processo de transformação da partícula integrante da estrutura do solo em uma partícula solta, ou seja, em uma partícula sedimentar. A partir desse momento fica sujeita ao transporte e deposição pela ação do escoamento.

A inclusão do fenômeno de deposição no conceito de erosão, corresponde à constatação de que o desprendimento e o transporte de partículas é sempre acompanhado por esse fenômeno (Lal, 1988). Foster et al. (1985) descrevem detalhadamente a dinâmica do processo erosivo em que tais fenômenos se combinam, desde o início de uma chuva, até o final do evento. A análise desses autores é fundamentada nas relações existentes entre a capacidade de transporte de um escoamento superficial e a carga transportada, que definem a deposição das partículas pelo fluxo da água. Desta maneira, podem-se formar depósitos de sedimentos, efêmeros ou não, em qualquer posição de uma vertente, mas preferencialmente nos sopés, em depressões do terreno ou, enfim, onde houver atenuações eficazes da velocidade de escoamento superficial.

Segundo FAO (1992) existem vários tipos de erosão hídrica, sendo que os principais são: erosão laminar, erosão em sulcos, erosão de ravina e boçoroca ou voçoroca. Na erosão laminar o solo é removido com certa uniformidade em toda a extensão do declive. No entanto, esse tipo é, via de regra, acompanhado sobretudo em terra desnuda, recém plantada ou alqueivada por várias ravinas minúsculas com 
dispersão irregular, o que é denominado erosão em sulcos. Quando porém, a água se concentra em maior quantidade, ocorre a formação de pequenas ou grandes ravinas, por solapamento ou escavação descendente, o que é denominado erosão em ravina.

Brady (1989) relata que, embora todos os tipos sejam nocivos, os prejuízos resultantes das erosões laminar e de sulcos (Figura 1), apesar de menos visíveis, sem nenhuma dúvida, são mais importantes no que diz respeito à degradação dos solos cultivados e, por isso, serão discutidos mais detalhadamente a seguir.

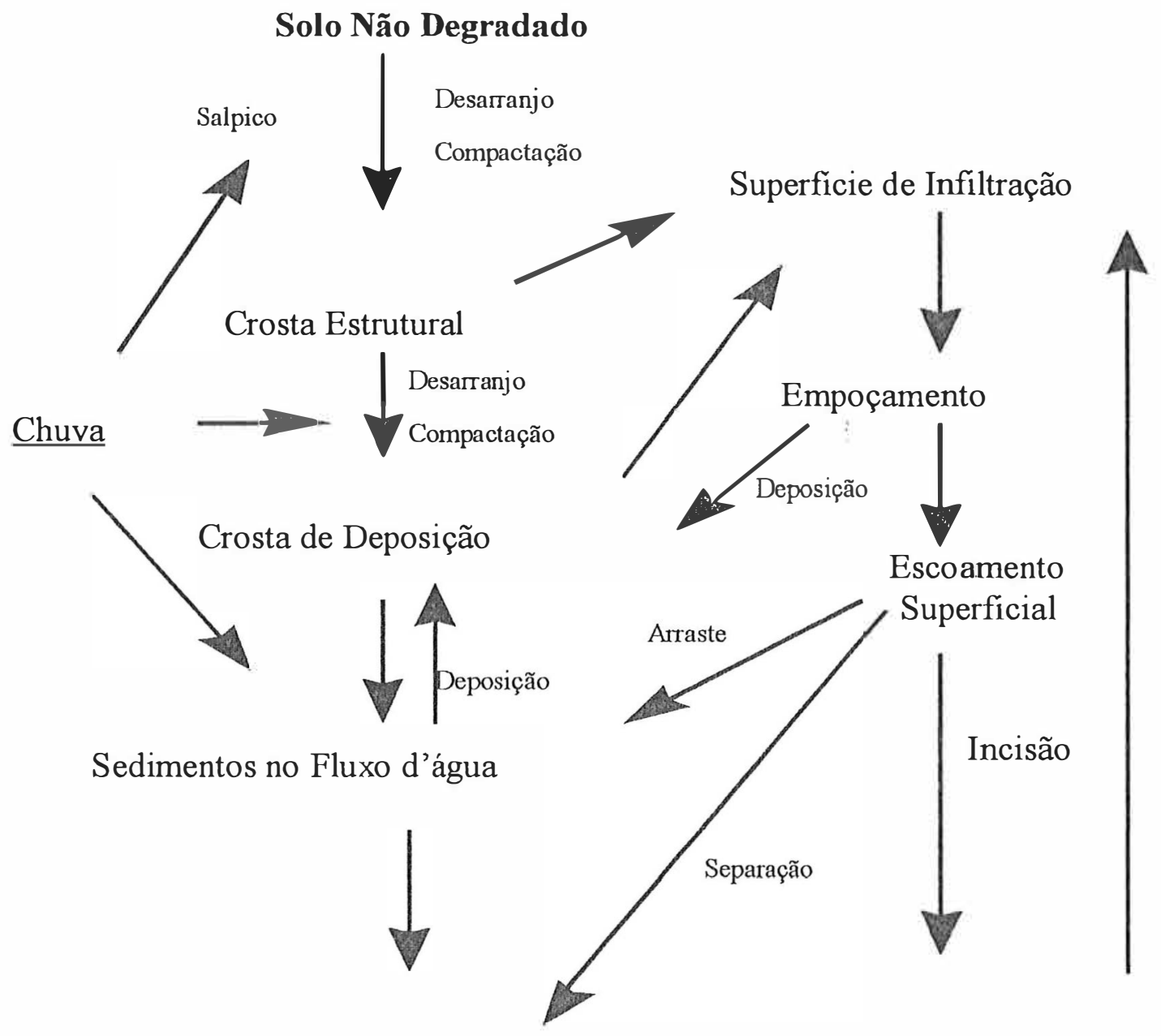

Erosão Laminar

Erosão em Sulco

Figura 1 - Diagrama de relações entre a demolição de agregados, crostas de deposição e erosão. Adaptado de Le Bissonnais (1996). 


\subsubsection{Erosão Laminar}

O escoamento em lençol superficial difuso, ou não concentrado, é o escoamento responsável pela erosão hídrica denominada laminar (Bertoni \& Lombardi Neto, 1990) ou em lençol, ou ainda, superficial (Bellinazzi et al., 1981; Bigarella \& Mazuchowski, 1985). Alguns autores, como Lepsch (1983), usam a expressão laminar, embora considerem que ela significa "erosão em pequenos filetes interligados que não deixam marcas perceptíveis na superficie do solo", e não necessariamente uma forma de erosão promovida por uma lâmina ou camada regular e homogênea de água cobrindo uma vertente. Entretanto, o termo laminar aqui adotado refere-se à erosão provocada pelo escoamento superficial difuso, que não provoca incisões significativas no solo, na escala de uma vertente, sendo que seus efeitos mais pronunciados são notados de forma indireta.

Segundo Bertoni \& Lombardi Neto (1990), a erosão laminar "é uma forma de erosão difícilmente perceptível", mas cuja ação pode ser denunciada pela coloração mais clara do solo, pela exposição de raízes e pela queda da produtividade agrícola. Lepsch (1983), relata que a erosão laminar pode ser identificada pela ausência parcial ou total de horizontes do perfil do solo, fundamentando assim a classificação de intensidades desse tipo de erosão.

De acordo com Roose (1998), a perda de solo por erosão laminar depende de fatores naturais, que podem ser agrupados em três conjuntos:

a) ligados à natureza do solo, envolvendo principalmente as suas características fisicas e morfológicas, tais como: textura, estrutura, permeabilidade, etc.;

b) ligados à morfologia do terreno, envolvendo a conformação de encosta, no que se refere principalmente à declividade e comprimento da encosta;

c) ligados ao clima, envolvendo a quantidade de água (especialmente a intensidade das chuvas) que atinge a superficie do terreno, causando remoção do solo. 


\subsubsection{Erosão Linear}

A erosão linear, em sulcos, sucede à erosão laminar. Entretanto, não existe nenhum limite definido que assinale o final da erosão laminar e o começo da erosão em sulcos (Roose, 1994). Bigarella \& Mazuchowski (1985) relatam que, com a continuidade das chuvas, a concentração do escoamento tende a ocorrer em linhas preferenciais persistentes, podendo provocar o sulcamento e outras feições erosivas lineares mais definidas e permanentes que os pequenos filetes de água, anastomosados, do início do escoamento superficial difuso.

Queiroz Neto \& Christofoletti (1968) descrevem que “... o escoamento em lençol, dessa forma, caracteriza-se por efetuar-se através de inúmeros filetes anastomosados por entre tufos de vegetação. À medida que descem as encostas, os filetes vão se engrossando, devido ao aumento da quantidade de água". Dessa maneira, prosseguem os autores, concorrem para "provocar o sulcamento das encostas, dando início aos processos de ravinamento...".

De filetes a sulcos e destes a ravinas ou voçorocas, as feições erosivas lineares são agronomicamente classificadas segundo suas relações com o manejo do solo, conforme manual de levantamento da capacidade de uso da terra. Assim, os sulcos são classificados como superficiais, quando podem ser cruzados por máquinas agrícolas e se desfazem com o preparo do solo; como rasos, quando podem ser cruzados por máquinas agrícolas, mas não se desfazem com o preparo do solo; profundos, quando não podem ser cruzados por máquinas agrícolas mas ainda não atingiram o horizonte $\mathrm{C}$ do solo e, finalmente, muito profundos, quando o horizonte $\mathrm{C}$ é atingido. Este último tipo também é chamado de boçoroca ou voçoroca (Lepsch, 1983).

Segundo Oliveira (1994), as diferentes classes de erosão, com vistas à produção de sedimentos, são: laminar ou entre sulcos, em sulcos, em calha, em ravinas e em voçorocas. A erosão laminar ou entre sulcos, já foi mencionada anteriormente. A erosão em sulcos decorre do escoamento superficial concentrado que comanda o desprendimento das partículas do solo, e o transporte das partículas desprendidas, segundo as condições hidráulicas desse escoamento. O mesmo modelo de escoamento 
intervém na calha que, embora de maior porte, ainda possui, lateralmente e a montante, bordas que se ajustam, sem ruptura, à superficie do terreno, ou seja, suficientemente suaves para apresentarem apenas mecanismos de erosão partícula a partícula.

$\mathrm{Na}$ ravina, entretanto, devem ainda ser considerados mecanismos de erosão que envolvam movimentos de massa, representados pelos pequenos deslizamentos que provocam o alargamento da feição erosiva e também seu avanço remontante. Por isso, suas bordas, ao contrário das calhas, são abruptas em relação à superfície original do terreno, configurando-se uma nítida ruptura instável (Roose, 1998).

Finalmente, por sua maior complexidade quanto aos fenômenos envolvidos, destacam-se as voçorocas, que constituem as principais feições erosivas do ponto de vista da produção de sedimentos e desenvolvem-se sob a ação combinada das concentrações de escoamentos, tanto superficiais quanto subsuperficiais (Oliveira, 1994). Segundo IPT (1994), pode-se destacar o fenômeno característico da voçoroca, ou seja, a erosão tubular regressiva ou "piping". Este fenômeno é provocado pela surgência da água de subsuperfície, no interior da feição erosiva, mobilizando forças de percolação capazes de arrastar as partículas de solo e assim formar vazios subterrâneos que se podem propagar a distâncias de vários metros, provocando colapsos do terreno.

Além do "piping", vários outros fenômenos, como liquefação de areias, areias movediças, movimentos de massa de diversos tipos, como deslizamentos, quedas de blocos, corridas de areia, etc., qualificam a voçoroca como uma feição erosiva não só de grande porte, mas de alto poder de produção de sedimentos (Oliveira, 1994).

Segundo Guerra et al. (1995), os impactos ambientais advindos da erosão dos solos, são encontrados tanto nas áreas erodidas, como naquelas adjacentes e até nas mais afastadas. O primeiro caso, refere-se à erosão laminar, às ravinas e voçorocas que além da remoção de materiais, impossibilitam por vezes, a mecanização, reduzem os teores de nutrientes e de matéria orgânica do solo, diminuindo assim, a sua fertilidade.

Wild (1993) relata que o processo de erosão acelerada, além de reduzir a fertilidade do solo, pode por vezes remover completamente o horizonte A, que contém a maior parte dos nutrientes utilizados pelas plantas e da matéria orgânica existente nos solos e, além disso, a melhor estrutura para o desenvolvimento das raízes. O material 
erodido pode ser transportado à curta, média e longa distâncias e ser depositado nos terrenos mais deprimidos que, se tiverem sido recentemente cultivados, poderá dificultar o desenvolvimento das sementes e a própria emergência dos vegetais acima da superfície do solo, causando prejuízos à agricultura.

Segundo Lombardi Neto (1992), para uma produção média de $3 \mathrm{t}^{\text {ha }}{ }^{-1}$ de milho, em solos Podzólicos, perdem-se $15 \mathrm{t} \mathrm{ha}^{-1}$ ano $^{-1}$ de solo, nos quais são arrastados $14 \mathrm{~kg}$ de $\mathrm{N}, 1 \mathrm{~kg}$ de $\mathrm{P}_{2} \mathrm{O}_{5}$ e $0,5 \mathrm{~kg}$ de $\mathrm{K}_{2} \mathrm{O}$. Estes teores equivalem a cerca de 20 , 2 e $2 \%$, respectivamente, da dose média desses fertilizantes aplicados para esta cultura. $\mathrm{O}$ mesmo autor estimou, para uma determinada microbacia de 3.200 ha, uma perda de 45 mil toneladas de solo por ano, quantidade essa que carrega fertilizantes, causando prejuízos da ordem de 45 mil reais com nitrogênio, 950 reais com potássio e 2.800 reais com calcáreo.

Outra conseqüência das perdas de solo por erosão é o seu impacto nos recursos hídricos (Lal, 1998). Este impacto manifesta-se, principalmente, através do assoreamento dos corpos d'água e reservatórios e a deterioração da qualidade das mesmas (IPT, 1994). Uma das mais sérias conseqüências provocadas pelo assoreamento é a promoção de enchentes e a perda de capacidade de armazenamento d'água (Kertzman et al., 1995; Roose, 1998), gerando problemas de abastecimento e de produção de energia (São Paulo, 1989).

Segundo IPT (1986), tendo em vista a gravidade destes problemas, é fundamental contemplá-los nos estudos regionais de erosão.

Entretanto, a carência de dados relacionados aos cursos d'água e enchentes, obtidos por monitoramento das bacia hidrográficas, dificulta sobremaneira a realização de estudos que permitam regionalmente, quantificar ou mesmo qualificar o impacto da erosão nos recursos hídricos (Prandini \& Nakazawa, 1995). 


\subsection{Equação Universal de Perda de Solo (EUPS)}

A utilização de equações empíricas para avaliação das perdas de solo por erosão vem se tornando prática indispensável para uma agricultura sustentada.

Os primeiros trabalhos para desenvolver equações que avaliassem as perdas de solo de uma dada área, datam de 1940, na região do Corn Belt dos Estados Unidos. O processo empregado a partir daquela época até 1956 era conhecido por método do plantio em declives. No Brasil, os trabalhos iniciais sobre a equação de perdas de solo foram desenvolvidos em 1975, utilizando dados existentes para as condições do Estado de São Paulo. A partir dessa data, vários autores vêm tentando avaliar os fatores da equação para outras regiões (Bertoni \& Lombardi Neto, 1990).

A equação universal de perda de solo exprime a ação dos principais fatores que sabidamente influenciam a erosão pela chuva. A equação desenvolvida por Wischmeier \& Smith (1978), é expressa em função de seis variáveis ambientais e de manejo:

$$
\mathbf{A}=\mathbf{R} \cdot \mathbf{K} \cdot \mathbf{L} \cdot \mathbf{S} \cdot \mathbf{C} \cdot \mathbf{P}
$$

sendo:

$\mathbf{A}=$ estimativa de perda total de solo por unidade de área;

$\mathbf{R}=$ fator que expressa a capacidade da chuva em provocar erosão, conhecido como erosividade. É definido como o produto da energia cinética de uma chuva em $\mathrm{MJ}$ ha $^{-1}$ pela sua intensidade máxima em 30 minutos em mm hora ${ }^{-1}$, somada para todo o período considerado;

$\mathbf{K}=$ fator relativo às propriedades inerentes ao solo, tais como textura, estrutura, matéria orgânica e permeabilidade, e que reflete sua maior ou menor susceptibilidade à erosão, sendo conhecido com erodibilidade;

$\mathbf{L}=$ fator relativo ao comprimento do declive da encosta. É referenciado segundo padrão de $22,3 \mathrm{~m}$, valor modal encontrado para o campo experimental de Wischmeier e Smith (1978); 
$\mathbf{S}$ = fator relativo à declividade da encosta, expresso em \%. Refere-se originalmente a um gradiente de $9 \%$, inclinação modal dos sítios de amostragem utilizados no desenvolvimento desta equação. Por conveniência é integrado ao fator L, definindo o fator topográfico;

$\mathbf{C}=$ fator relativo ao fator cultural, associado a eficiência da cobertura vegetal e técnicas de manejo agrícola na proteção do solo. Varia de 0,0 para coberturas que proporcionam proteção total a 1,0 para solos inteiramente expostos;

$\mathbf{P}=$ fator relativo à prática conservacionista adotada. Varia de 0,0 a 1,0 , sendo que as práticas mais comuns são plantio em curva de nível, plantio direto, cordões de vegetação etc.

Os fatores $\mathrm{R}, \mathrm{K}, \mathrm{L}$ e $\mathrm{S}$ são dependentes das condições naturais e os fatores $\mathrm{C}$ e $\mathrm{P}$ são relacionados às formas de ocupação e uso das terras (fatores antrópicos).

Segundo Ranieri (1996), a EUPS pode ser aplicada para as seguintes finalidades: a) previsão de perdas anuais médias de solo de uma área sujeita a determinadas práticas de utilização; b) orientação na seleção de áreas de cultivo, de manejo e conservação; c) previsão de alterações nas perdas de solo ocasionadas por mudanças nas práticas de cultivo e conservação; d) determinação de modos de aplicação ou alteração das práticas agrícolas que permitam usos mais intensivos da terra; e) estimativas das perdas de solo para usos distintos na agricultura e f) estimativa das perdas de solo visando a determinação de práticas conservacionistas.

A EUPS apresenta algumas limitações, como por exemplo, o fato de não considerar aspectos morfológicos de encostas (convexidade, concavidade), adotando-se condições uniformes (perfis retilíneos) para as mesmas. Outro problema está relacionado à aplicação desse modelo em áreas como uma bacia hidrográfica de grande extensão, posto que a equação foi desenvolvida para ser aplicada em glebas homogêneas. Sobre este aspecto, Hamlet et al. (1992) apontam a problemática principal do cálculo do comprimento de declive em uma bacia hidrográfica.

Por sua vez, Castro (1992) aponta o erro ocorrido na estimativa de perda de solo para bacias hidrográficas no fato de a EUPS considerar este processo como sendo de caráter contínuo, não contemplando o fenômeno de deposição nas encostas. $\mathrm{O}$ mesmo 
autor também levanta a problemática da subjetividade representada pela abordagem semi-quantitativa de algumas variáveis da EUPS.

Pode-se relacionar também, como uma limitação do modelo, o fato deste apenas estimar as perdas de solo por erosão laminar e em pequenos/rasos sulcos; não contemplando portanto, erosão em sulcos profundos, voçorocas e movimentos de massa.

O modelo foi desenvolvido para ser aplicado em áreas com declividade de até $25 \%$, sendo que nos locais com declividade superior a este valor, estar-se-á realizando uma estimativa de perdas de solo inadequada (Roose, 1998).

Apesar destas limitações, a EUPS é considerada um bom instrumento para previsão de perdas de solo por erosão laminar, por exigir um número de informações relativamente pequeno quando comparado a modelos mais complexos e por ser uma equação bastante conhecida e estudada (Pelletier, 1985; Bertoni \& Lombardi Neto, 1990; Castro, 1992; De Lima et al., 1992; Donzeli et al., 1992; Hamlet et al., 1992; Bacellar, 1994; Jäger, 1994; Fraser et al., 1995; Desmet \& Govers, 1996; Ranieri, 1996; Roose, 1998).

\subsection{Sistema de Informação Geográfica (SIG)}

O termo Geoprocessamento refere-se à aquisição, processamento e análise de dados espacialmente distribuídos, englobando portanto, Sistema de Informação Geográfica (SIG), Sensoriamento Remoto e Sistema de Posicionamento Global (GPS) (Star \& Estes, 1990). Embora as técnicas de sensoriamento remoto e GPS tenham sido contempladas na presente pesquisa, utilizou-se com maior ênfase Sistema de Informação Geográfica, justificando assim, sua aboradagem nesta terceira parte da revisão da literatura. 


\subsubsection{Breve Histórico}

O primeiro Sistema de Informação Geográfica (SIG) foi desenvolvido em meados da década de 60 por agências governamentais como resposta a uma nova consciência e urgência em lidar com questões ambientais complexas e recursos naturais (Ballester, 1996). Um dos pioneiros neste campo foi o Sistema de Informações Geográficas do Canadá (CGIS), criado para processar a imensa quantidade de dados obtidos pelo Inventário de Terras do Canadá. Pouco depois, tiveram início vários outros sistemas, como por exemplo, o do Estado de Minessota (E.U.A.). Estes sistemas estão ainda em funcionamento, apesar de sua estruturação atual ser bastante diferente daquela original. Muitos dos sistemas inicialmente desenvolvidos tiveram uma vida curta. Isto deveu-se, em parte, à elevada demanda de performance acoplada a problemas técnicos encontrados na tentativa de sanar tais limitações com uma tecnologia incipiente. (Demers, 1997).

$\mathrm{Na}$ década de oitenta, o uso de SIGs cresceu drasticamente, tornando-se uma ferramenta comum em muitas instituições privadas, governamentais, de ensino e pesquisa. Atualmente, é o resultado de mais de duas décadas de desenvolvimento científico e, como muitas inovações tecnológicas, tem aumentado rapidamente sua taxa de adoção após muitos anos de crescimento lento (Ballester, 1996).

O histórico do uso de computadores para o mapeamento e análise espacial mostra que tem existido um desenvolvimento paralelo entre a caputura automatizada de dados, sua análise e apresentação em vários campos do conhecimento humano. Estes campos são os da cartografia, geografia, matemática, sensoriamento remoto, fotogrametria, etc, denotando a forte característica interdisciplinar dos SIGs (Petersen et al., 1997). 


\subsubsection{Conceitos e definições}

Os SIGs são destinados ao tratamento de dados referenciados espacialmente. Estes sistemas manipulam dados de diversas fontes, como mapas, imagens de satélites, cadastros e outras, permitindo combinar informações e efetuar os mais diversos tipos de análises (Alves, 1990; Goodchild, 1993; Ballester, 1996).

Um SIG pode ser definido como uma ferramenta para a aquisição, armazenamento, manipulação, integração e exposição de dados ambientais (Burrough, 1986; Star \& Estes, 1990; Dobson, 1993).

Contudo, isto não é suficiente para caracterizar um SIG. Para tal devem ser levadas em consideração suas diferentes partes (Burrough, 1986):

a) SIG é uma tecnologia para a investigação dos fenômenos ambientais que combina os avanços da cartografia automatizada, sistemas de manipulação de banco de dados e sensoriamento remoto, com um desenvolvimento metodológico em análise geográfica para produzir um conjunto distinto de procedimentos analíticos com base em um banco de dados único georreferenciado e integrado;

b) SIGs têm, predominantemente, uma orientação espacial nas suas capacidades de busca e análise, podendo posicionar geograficamente feições da superfície terrestre. Conceitualmente, SIG é um mapeador automatizado que possui algorítmos de manipulação dos dados que permitem combinar vários tipos de informações para gerar mapas temáticos e derivados;

c) SIGs não são ferramentas para inventários de informação simplesmente, mas o são para modelagem, podendo ser utilizadas para simular e testar modelos e/ou prever acontecimentos.

Um aspecto importante a ser ressaltado é que um SIG não é apenas um programa para o processamento de dados georreferenciados, mas sim uma tecnologia com quatro componentes importantes (Burrough, 1986, Guptill, 1989): um "hardware", um conjunto de módulos aplicativos a um "software", um contexto organizacional próprio ou interface com o usuário e um banco de dados digital georreferenciado o qual será manipulado pelo SIG 
Entre as razões apontadas na literatura (Burrough, 1986; Star \& Estes, 1990; Dobson, 1993) para o uso de um SIG, as mais comuns são:

a) Os dados são mantidos em um formato fisicamente compactado (arquivos magnéticos), podendo ser mantidos e extraídos a um custo menor por unidade de dado manipulado e acessados a uma velocidade muito maior;

b) Várias ferramentas computacionais permitem uma variedade de tipos de manipulação, entre as quais incluem-se medidas e sobreposição de mapas, transformações, desenhos gráficos e manipulação de bancos de dados;

c) Informações gráficas e não gráficas podem ser fundidas e manipuladas simultaneamente de uma maneira relacionada;

d) Podem ser efetuados testes analíticos de modelos conceituais de modo rápido e repetidamente (ex: sustentabilidade ou capacidade do solo), facilitando as avaliações em grandes áreas em um curto período de tempo;

e) Análises de mudanças podem ser efetuadas em dois ou mais períodos de tempo;

f) As ferramentas de desenho gráficos interativo e automatizado podem ser aplicadas na produção e desenho cartográfico;

g) Certos tipos de análises podem ser realizadas muito mais eficientemente em termos de custos do que se efetuadas manualmente (ex: análises digitais de terrenos, declividade, insolação, bacias de drenagem, sobreposição de múltiplos conjuntos de mapas contendo polígonos complexos etc);

h) Existe uma tendência resultante de integrar dados coletados, análises espaciais e processos de tomada de decisões, em u m contexto de fluxo de informação comum. Isto representa grandes vantagens em termos de eficiência e custos.

Os mesmos autores citam uma série de desvantagens, entre as quais:

a) O custo e os problemas associados na conversão de dados geográficos existentes em um arquivo automatizado (digitalização, vetorização etc);

b) A grande quantidade de recursos técnicos e financeiros para a manutenção de um SIG ("software" e "hardware");

c) Custo inicial elevado para a aquisição do sistema. 


\subsection{Exemplos de utilização de SIG em estudos de erosão}

A erosão do solo pode ser estimada de forma qualitativa ou quantitativa. Segundo Chaves et al. (1995), as duas formas apresentam vantagens e desvantagens. A análise qualitativa tem como principal vantagem a facilidade de manipulação dos fatores selecionados em termos de grau de risco a erosão e sua posterior combinação para a obtenção dos graus de severidade erosiva. Entretanto, sendo qualitativa, a estimativa da erosão não permite a obtenção de valores numéricos, importante para a estimativa da degradação do solo e da sedimentação. Já a análise quantitativa permite a estimativa da erosão absoluta, facilitando o planejamento conservacionista. Entretanto, os modelos quantitativos exigem um maior conhecimento por parte do usuário, além de requerer mais informações do que os modelos qualitativos.

A aplicação de modelos quantitativos foi intensamente facilitada com o desenvolvimento dos SIGs. A aplicação do modelo EUPS em ambiente SIG vem sendo objeto de investigação de diversos autores, mencionados a seguir.

O procedimento usual de aplicação do modelo EUPS em SIG, pode ser resumido segundo Pelletier (1985) em: (a) registro dos planos de informação referenciados em relação a uma base cartográfica (UTM, Mercator, etc.), de forma a conferir uma mesma coordenada geográfica para os pontos independentemente do plano de informação em que estejam situados, e ainda um mesmo posicionamento no banco de dados digital (x, y). A seguir, (b) são calculados os valores para cada plano de informação segundo a EUPS. Com base nestes dados, (c) são efetuadas as operações de integração com vistas a estabelecer os valores finais para o índice " $A$ ", que representa a estimativa de perda total de solo por unidade de área.

Ventura et al. (1988) procederam à aplicação deste modelo como elemento de apoio ao planejamento regional entre o potencial natural de perdas de solo e os valores estabelecidos como toleráveis para as diferentes classes de solo.

Pinto (1991) propôs metodologia analítica que considera a incorporação direta de imagens geradas por sensores orbitais. $\mathrm{O}$ autor fez uso de uma série de técnicas de processamento digital de forma a obter uma melhoria na interpretabilidade das imagens 
e detectar indícios de processos erosivos. As informações referentes ao padrão de uso e ocupação da bacia estudada, foram posteriormente integradas aos descritores físicos do ambiente por intermédio de um SIG, resultando em valores de perdas de solo.

Castro (1992) utilizou a EUPS para estimar perdas de solo em uma bacia hidrográfica a fim de definir classes de susceptibilidade em função do meio físico. A estimativa de perdas de solo foi calculada utilizando o SIG-INPE do Instituto Nacional de Pesquisas Espacias (INPE). Este mesmo autor constatou em sua pesquisa, que o uso dos SIGs e o processamento de imagens de satélites têm permitido a utilização mais intensiva de dados de sensores remotos, através do aprimoramento das técnicas de classificação digital. Estes instrumentos podem ser definidos como elementos básicos de apoio a um sistema de monitoramento ambiental, em especial quanto aos processos de erosão dos solos e da degradação dos recursos naturais renováveis.

Hamlet et al. (1992) aplicaram a EUPS para a predição de perda de solo, através de SIG, para determinar áreas críticas quanto à fonte de poluição não pontual para os rios de 104 bacias hidrográficas, na escala de 1:250.000. Os autores relataram limitações ao se trabalhar com esse modelo em bacias hidrográficas, principalmente pela dificuldade no cálculo do comprimento do declive dentro de cada bacia, em função da limitação do modelo empregado. Estes mesmos autores sugeríram que o cálculo de perda de solo por erosão em áreas de menores dimensões deve ser efetuado com modelos de predição mais sofisticados.

De Lima et al. (1992) apresentaram um método de utilização do SIG-INPE e dados de sensoriamento remoto orbital para gerar mapas de risco de erosão do solo para a região do Sertão da Paraíba. Os autores integraram os planos de informação relativos à erodibilidade, erosividade, litologia e declividade, para obterem um mapa de risco potencial natural de erosão. Através de dados digitais do satélite LANDSAT sensor TM, obtiveram um mapa de cobertura vegetal, que integrado ao de risco potencial natural de erosão, originou o mapa de risco de erosão atual. Os resultados demonstraram que o método adotado foi bastante satisfatório, inclusive se comparado com os procedimentos convencionais, principalmente pelo fato de possibilitar a elaboração de mapas para grandes áreas. 
$\mathrm{Na}$ Alemanha, Jäger (1994) utilizou a EUPS para gerar mapas de susceptibilidade à erosão em uma área de cerca de $36.000 \mathrm{~km}^{2}$, através du SIG-Idrisi. No trabalho foi estimada a perda de solo e determinadas as classes de susceptibilidade à erosão pela tolerância de perda de solo. O autor apontou dificuldades e limitações no método adotado, principalmente com relação ao cálculo do fator LS. Enfatizou, porém, que o uso da EUPS através de SIG ainda é um método muito útil para trabalhos em escala regional.

Na Dinamarca, Balstroem (1994) gerou mapa de risco potencial de erosão para uma pequena região $\left(100 \mathrm{~km}^{2}\right)$, baseado nas informações relativas a um banco de dados de solos, um mapa da rede de drenagem, um modelo digital de elevação do terreno e um mapa do uso da terra derivado de imagem de satélite. Os planos de informações foram sobrepostos através do SIG ARC-INFO. Os resultados, segundo o autor, foram satisfatórios. Todavia, o autor sugeriu o uso de fotografias aéreas com o intuito de se obter dados mais acurados sobre o uso da terra.

O uso da EUPS em SIG também foi estudado por Fraser et al. (1995), para comparar três diferentes fontes de dados de cobertura da terra, no cálculo das perdas de solo de uma bacia hidrográfica na região de Nova York (Estados Unidos). Foram utilizados dados de fotografias aéreas e imagens do satélite Lansat sensores MSS e TM. Segundo os autores, a classificação do uso da terra variou de forma significativa entre as três fontes de dados distintas. Entretanto, a predição de erosão do solo foi similar. Os autores concluíram que a utilização de imagem Landsat-TM com um algorítmo de classificação híbrida, gera uma boa informação sobre o uso da terra em grandes áreas, de forma objetiva e rápida, e que pode ser utilizada na EUPS; tornando-se uma alternativa atrativa em comparação às fotografias aéreas.

Saiz \& Valério Filho (1996) utilizaram técnicas de tratamento de imagens digitais e SIG no levantamento e integração de dados, para contribuir no estudo do problema da erosão hídrica em uma área localizada no Partido de Tandil, Província de Buenos Aires, Argentina. A aplicação do modelo foi conduzida através da integração dos parâmetros da EUPS via SIG, que possibilitando a obtenção, inicialmente do Potencial Natural de Erosão (PNE) e posteriormente a obtenção do C permissível (Cp) 
pela seguinte relação $\mathrm{Cp}=\mathrm{T} / \mathrm{PNE}$; onde $\mathrm{T}$ expressa a perda de solo tolerada ou perda de solo permissível. Finalmente, foi calculado o Índice de Criticidade de Perdas por Erosão (IC), dado pela seguinte expressão IC $=\mathrm{A} / \mathrm{T}$. Segundo os autores, a integração da base de dados realizada conforme o modelo EUPS, mediante a aplicação de operações de potenciação, multiplicação, subtração e dos cruzamentos entre planos de informação implementados no SGI/INPE, permitiu a obtenção de bons resultados.

Na escala global, Batjes (1996) gerou mapa de vulnerabilidade do solo por erosão hídrica. Para tanto, utilizou uma metodologia, que consiste na integração dos fatores da EUPS, através do SIG ARC-INFO, gerando um mapa de susceptibilidade do solo. Este mapa por sua vez, foi cruzado com informações relativas à cobertura do solo, produzindo um mapa de vulnerabilidade da terra. O mapa de vulnerabilidade integrado com dados de degradação dos solos obtidos no terreno, geraram um modelo de avaliação do estado atual e do potencial de degradação do solo para o globo terrestre.

Desmet \& Govers (1996) compararam dois métodos de cálculo do fator LS da EUPS, o método manual e o outro com a utilização de um algorítmo computacional. Os resultados mostraram que os métodos apresentaram dados similares em termos de mapeamento de risco de erosão relativo. Porém, apresentaram diferenças importantes com relação aos valores absolutos. O método manual tende a subestimar valores de risco de erosão, em função da não consideração da convergência no escoamento da água. $\mathrm{O}$ procedimento computacional possui a vantagem da fácil integração das informações em um SIG, pela sobreposição dos planos de informação.

Com base em dados de levantamentos de campo, Moraes et al. (1996) criaram um banco de dados de solos em um SIG. Posteriormente, geraram mapas temáticos, contendo informações sobre classes de declive, solos, orientação de vertente e comprimento do declive. Com essas informações, elaboraram, através de operações de superposição e reclassificação, mapas que representam o potencial natural de erosão e de expectativa de erosão. Os autores também estabeleceram as classes de capacidade de uso através da superposição do mapa de solos e do mapa contendo classes de declividade. Todas essas informações foram então analisadas visando estabelecer comparações entre o diagnóstico atual da microbacia estudada e o seu uso mais adequado, visando 
indentificar pontos críticos e estabelecer um planejameto de uso sustentado, com grupos de unidades de manejo.

Ranieri (1996) analisou e discutiu métodos e escalas de trabalho para a obtenção de mapas de risco de erosão na microbacia hidrográfica do Ribeirão dos Marins, em Piracicaba-SP. Para tanto, utilizou um método quantitativo, com o uso da EUPS, e um qualitativo, baseado em mapas pedológicos, planialtimétricos e de uso da terra. Os resultados indicaram que nos dois métodos adotados não houve diferença significativa quanto à escala de trabalho, tanto para os mapas básicos quanto para os mapas de risco de erosão.

Em suas pesquisas, Sheng et al. (1997) utilizaram SIG para definir bacias hidrográficas prioritárias sob o ponto de vista de conservação do solo e da água. Os autores relataram os passos a serem seguidos na determinação dos parâmetros que influenciam na erosão do solo. Propuseram uma chave de decisão, para auxiliar o estabelecimento das prioridades, sendo que os fatores que devem ser considerados de forma mais efetiva são: declividade, erosividade, erodibilidade e cobertura vegetal. Os autores ainda sugeriram algumas alternativas, como por exemplo, a utilização de microcomputadores menos potentes (ao invés de estações de trabalho) e mapas menos detalhados, com a finalidade de reduzir os custos operacionais, para que essa técnica possa ser utilizada em países em desenvolvimento.

Mantel \& Van Engelen (1997) realizaram estudo de grande escala em regiões da Argentina, Uruguai e Kenia, gerando mapas, através de SIG, com a espacialização e tipologia das principais formas de degradação da terra e seus impactos na produção de alimentos. A erosão foi considerada, por esses autores, como uma das formas mais agressivas de degradação dos solos. Com a utilização de modelos de predição e constatações no terreno, foram gerados mapas e definiram-se cenários. Os autores ressaltaram que apenas parte do estudo está concluído, mas já puderam apontar a metodologia usada como adequada para o mapeamento, monitoramento e construção de cenários sobre o estudo de degradação das terras nesses países.

Guangwei (1997), diagnosticando terras degradadas em uma área de aproximadamente $43.700 \mathrm{~km}^{2}$ (abrangendo oito países da região semi-árida da Ásia), 
utilizou dados de sensoriamento remoto orbital e o SIG ARC-INFO para a integração das diferentes informações. Os resultados obtidos mostraram que, na região estudada, ocorrem os processos de erosão, desertificação, salinização e degradação da vegetação, sendo que os principais problemas estão relacionados à erosão e desertificação. O autor concluiu que o procedimento utilizado foi adequado no diagnóstico de áreas degradadas e que a tecnologia de geoinformação é uma ferramenta poderosa em estudos ambientais.

Gomes \& Maldonado (1998) apresentaram uma metodologia para avaliar as perdas de solo por erosão e determinar vulnerabilidade ambiental para a região semiárida do nordeste brasileiro. Utilizaram, como principal componente de análise, imagens Landsat sensor TM (bandas vermelho e infra-vermelho) em diferentes períodos hidrológicos. Os resultados obtidos nesse estudo indicaram diferentes características nas mudanças do uso da terra, que foram categorizadas em três classes: áreas degradadas, áreas não degradadas e áreas em processo de regeneração. Os autores consideraram o processamento de imagens adotado bastante adequado para trabalhos com o mesmo tipo de enfoque, demonstrando que dados orbitais são capazes de monitorar áreas como a região semi-árido do nordeste brasileiro.

Brito et al. (1998) estimaram as perdas de solo por erosão em uma pequena região de Minas Gerais, utilizando a EUPS e SIG. Através das técnicas de geoprocessamento, os autores determinaram que os valores de perdas de solo por erosão na área de estudo se encontram abaixo dos valores críticos (uma vez que cerca de $90 \%$ da área tem declividade inferior a $10 \%$ ) não comprometendo assim a sustentabilidade ambiental da microbacia. Concluíram que o SIG é uma ferramenta muito valiosa na integração dos dados de perda de solo por erosão e na geração de produtos cartográficos para avaliar e monitorar a sustentabilidade ambiental. 


\section{MATERIAL E MÉTODOS}

\subsection{Caracterização da área de estudo}

A bacia do rio Piracicaba, uma bacia hidrográfica de meso-escala, está localizada entre os paralelos $22^{\circ} 00^{\prime}$ e $23^{\circ} 30^{\prime}$ de latitude sul e os meridianos $45^{\circ} 45^{\prime}$ e $48^{\circ} 30^{\prime}$ de longitude oeste (Figura 2).

Os principais rios da bacia - Atibaia, Jaguari, Camanducaia, Corumbataí e Piracicaba (Figura 3), percorrem cerca de $250 \mathrm{~km}$ no sentido leste-oeste, desaguando no braço direito da represa Barra Bonita (CETESB, 1991). A bacia do rio Piracicaba pode ser dividida em quatro sub-bacias. A maior é a do rio Jaguari com $4.290 \mathrm{~km}^{2}$, seguindose a do rio Piracicaba $\left(3.650 \mathrm{~km}^{2}\right)$, a do rio Atibaia $\left(2.760 \mathrm{~km}^{2}\right)$ e, finalmente, a do rio Corumbataí $\left(1.700 \mathrm{~km}^{2}\right)$.

Esta bacia ocupa uma extensão de $12.400 \mathrm{~km}^{2}$, e é constituída por um total de 61 municípios, sendo que 55 estão localizados no Estado de São Paulo e 6 em Minas Gerais. As cidades mais populosas, de acordo com São Paulo (1991a), em ordem decrescente são: Campinas, Piracicaba, Limeira, Americana e Rio Claro; perfazendo quase $60 \%$ da população na bacia. 


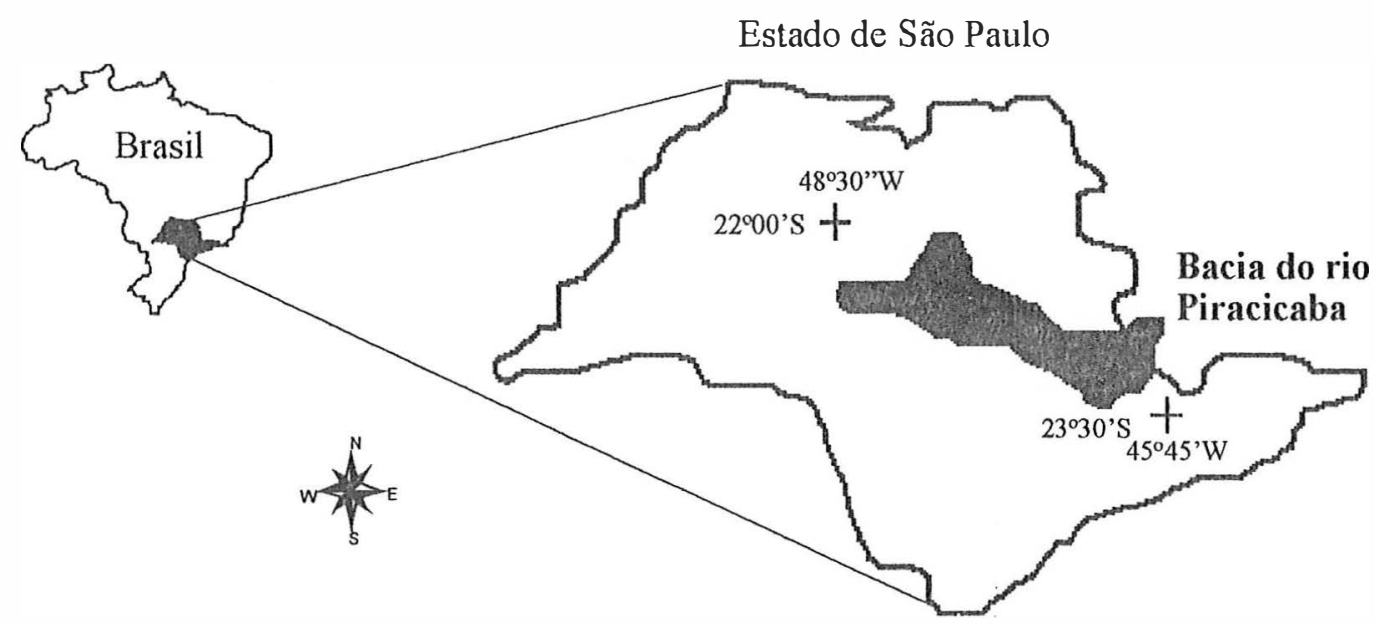

Figura 2. Localização da bacia do rio Piracicaba.

Abriga uma população crescente, estimada em três milhões de habitantes (São Paulo, 1991a). O crescimento desta região foi calculado em 2,5\% ao ano, que é superior à média do Brasil, estimada em 2,4 \% (São Paulo, 1994). A continuar as mesmas taxas de crescimento, é bem provável que no próximo século a população da bacia será de aproximadamente quatro milhões de habitantes.

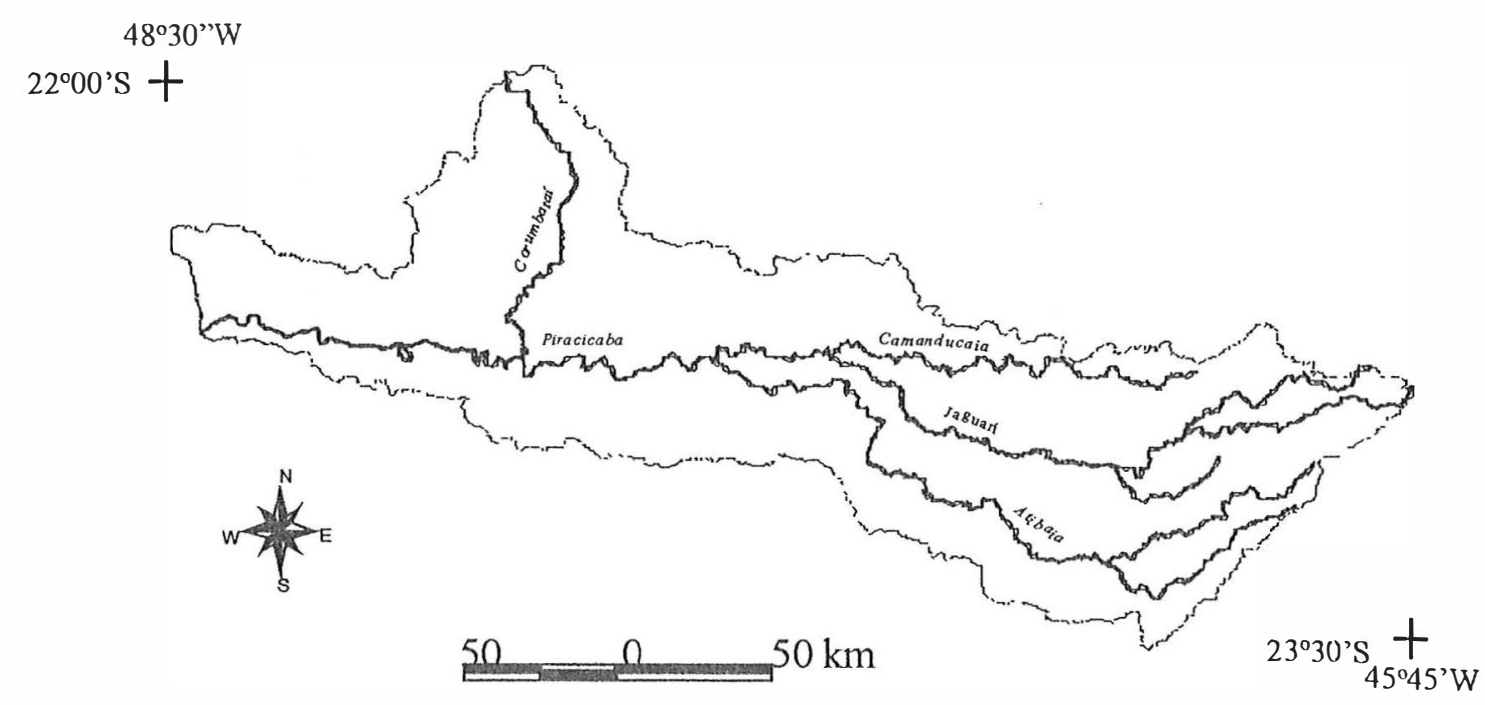

Figura 3. Principais rios da bacia. 
A geologia da bacia (Figura 4) é constituída pelas formações Bauru, Serra Geral e Botucatu-Pirambóia, pelos grupos Passa-Dois e Tubarão e Pré-Cambriano-Cristalino (São Paulo, 1991a).

Os solos predominantes na região são os Podzólico Vermelho-Amarelo e Latossolo Vermelho-Amarelo (São Paulo, 1994). Estes solos são normalmente ácidos, apresentam toxicidade por alumínio, porém, apresentam características fisicas favoráveis, sendo que $68 \%$ da área da bacia corresponde a terras potencialmente agricultáveis (São Paulo, 1992). O Centro de Energia Nuclear na Agricultura (CENA), constituíu um Banco de Dados de Solos da Bacia do Rio Piracicaba. Neste banco, foram arquivadas propriedades fisicas e químicas de 87 perfis de solos, compostos por 537 horizontes pedológicos. As principais classes de solos encontradas foram: Podzólico Vermelho-Amarelo, Latossolo Vermelho-Amarelo, Latossolo Vermelho-Escuro, Areia Quartzosa, Latossolo Roxo, Litossolo, Glei Pouco Húmico/Húmico, Terra Roxa Estruturada, solos Podzolizados e Regossolos. Através da análise dos dados do banco, pode-se dizer que a maioria dos solos possui textura argilosa e são de baixa fertilidade natural (Projeto Piracena, 1998).

A bacia pode ser dividida em dois grandes setores geomorfológicos: à montante de Campinas predominam as rochas cristalinas e, na porção restante, as rochas sedimentares e intrusivas da depressão periférica. O primeiro setor geomorfológico estende-se desde as cabeceiras até a porção média, apresentando um relevo montanhoso, com declividade média alta (acima de $15 \%$ ), rede de drenagem de elevada densidade e cotas variando de 2.000 metros nas cabeceiras até 600 metros nos fundos dos vales. $\mathrm{O}$ segundo setor corresponde aos terrenos sedimentares que formam a depressão periférica. $\mathrm{O}$ relevo é do tipo colinoso, predominando declividades menos acentuadas com cotas variando de 700 metros até pouco abaixo de 500 metros e drenagem de média a baixa densidade. O limite oeste da bacia é constituído por relevo característico de transição, com cuestas ou escarpas festonadas de declividade acima de $30 \%$, produto de erosão regressiva que atua sobre a sequêencia de basaltos e sedimentos sotopostos, formando anfiteatros separados por espigões com vertentes de perfis retilíneos (São Paulo, 1991a). 


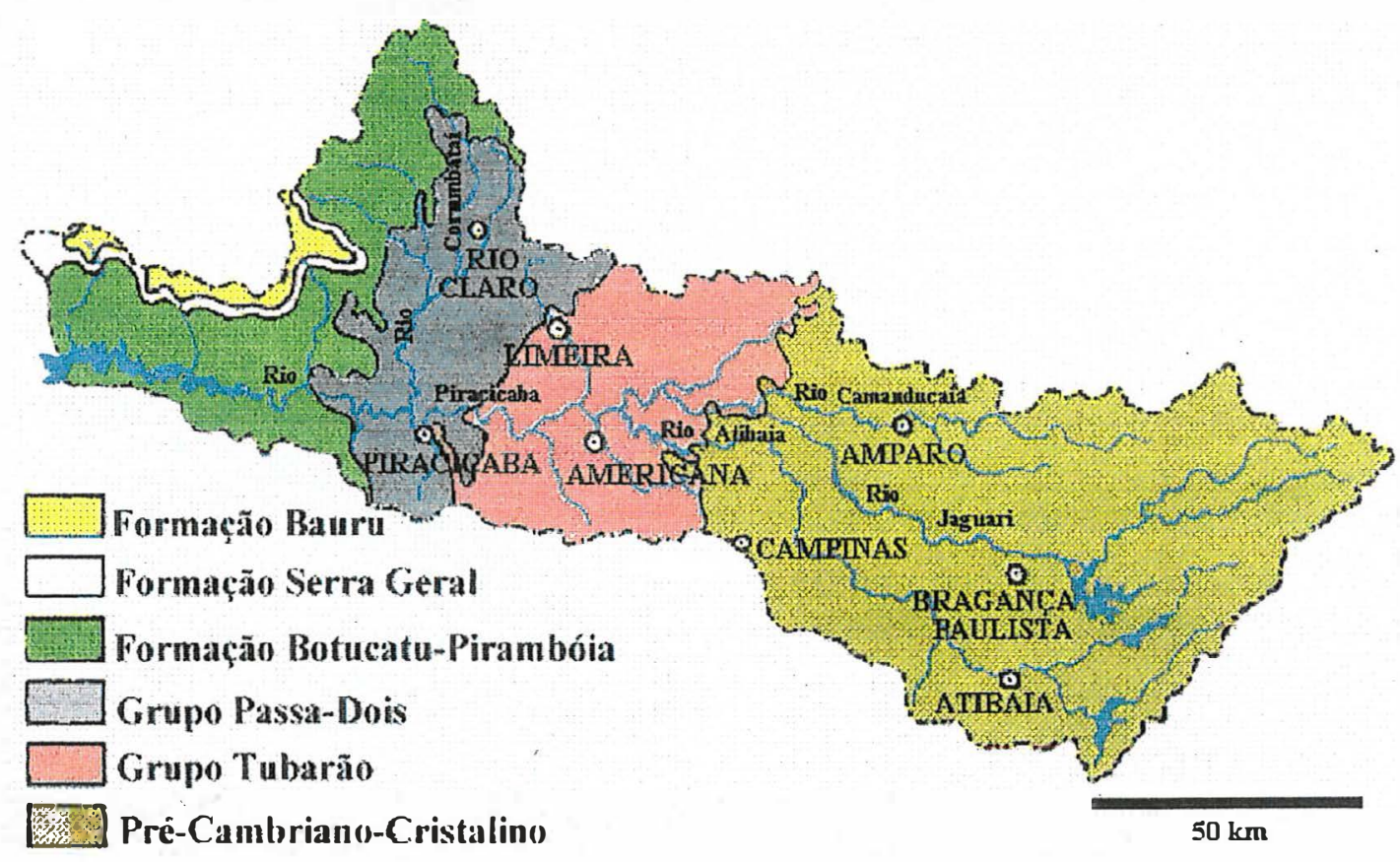

Figura 4. Mapa geológico da bacia do rio Piracicaba.

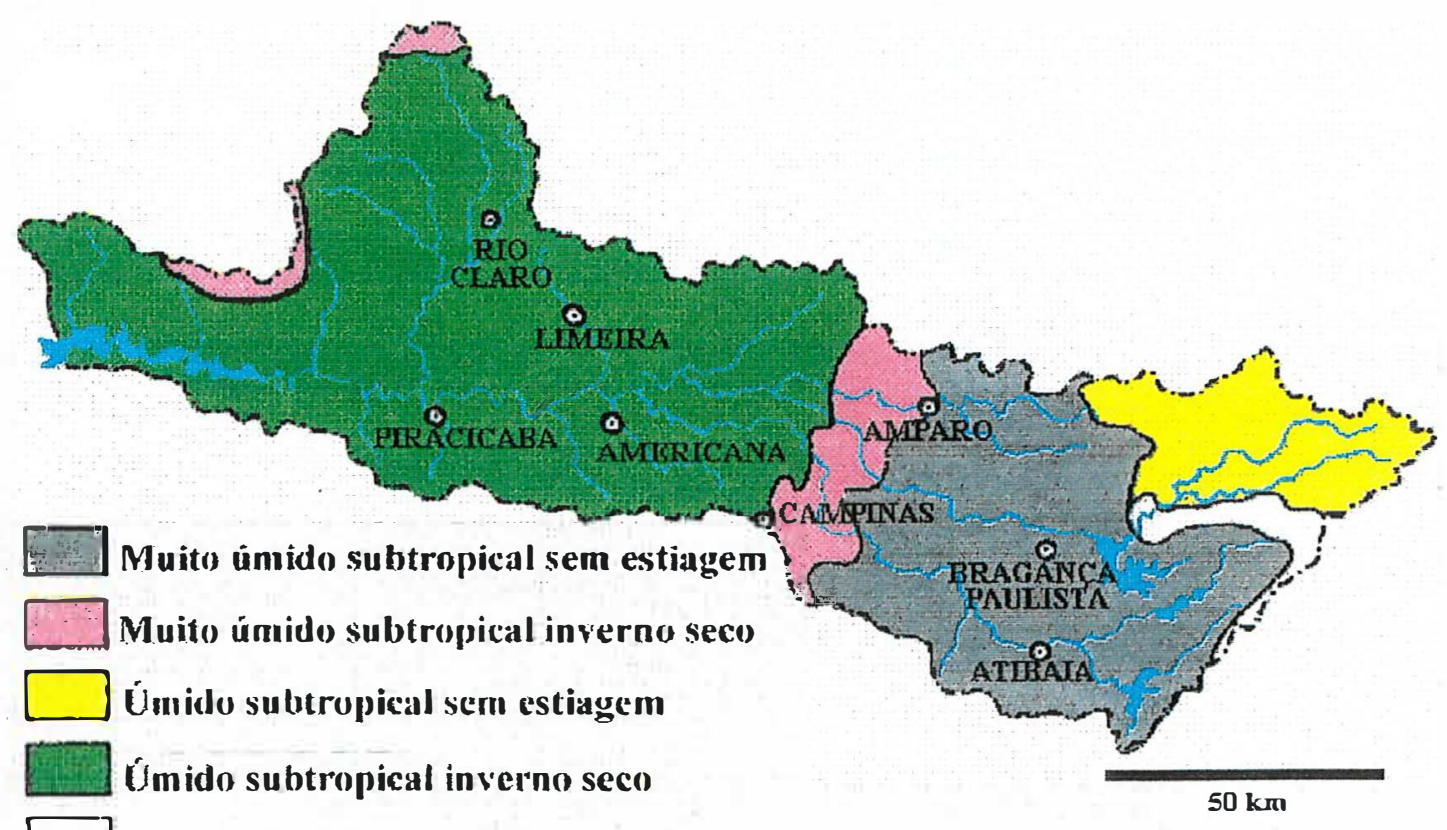
Super úmido temperado sem estiagem

Figura 5. Características climáticas da bacia do rio Piracicaba. 
O clima da região, segundo a classificação de Köeppen, é do tipo C, subtropical, com temperaturas médias anuais entre 18 e $22^{\circ} \mathrm{C}$ e com acentuada amplitude térmica entre os meses quentes e frios (Feltran Filho, 1982). As principais características climáticas da bacia, segundo São Paulo (1991a), são apresentadas na Figura 5. A precipitação média é de $1400 \mathrm{~mm}$ anuais, com regime caracterizado por duas estações bem distintas: seca no inverno (meses de abril a setembro) e chuvosa no verão (outubro a março). A precipitação média mensal do período seco é inferior a $20 \mathrm{~mm}$ e do úmido, próxima a $300 \mathrm{~mm}$, com $70 \%$ do volume ocorrendo no verão (Pellegrino, 1995).

Originalmente, a bacia era coberta principaimente por floresta subtropical semidecídua e áreas menores com cerrado (IGC, 1980). O início da ocupação intensiva da terra ocorreu no começo do século, com o cultivo de café e culturas de subsistência. Posteriormente o café foi substituído por pastagens e, mais recentemente, parte foi transformado em cultivos de cana-de-açúcar, citros e reflorestamentos com eucalipto (FUNDAP, 1991). A estimativa da distribuição atual das classes de uso da terra, mostra que cerca de $56 \%$ da área da bacia é constituída por pastagem, $20 \%$ por cana-deaçúcar, $8 \%$ por citros, $6 \%$ por vegetação nativa e silvicultura e $10 \%$ por zona urbana e outros usos (IGC, 1980; IGC, 1981).

\subsection{Material}

\subsubsection{Banco de dados}

Os materiais utilizados foram:

- Cartas planialtimétricas e hidrográficas, escala de 1:50.000, Quadrículas: Americana, Amparo, Araras, Atibaia, Barra Bonita, Bragança Paulista, Brotas, Camanducaia, Cambuí, Campinas, Capivari, Conchal, Corumbataí, Cosmópolis, Dois Córregos, Extrema, Guarulhos, Indaiatuba, Itaquaquecetuba, Itirapina, Igaratá, Jundiaí, Laras, Leme, Limeira, Mogi-Guaçú, Monteiro Lobato, Munhoz, Paraisópolis, Piracaia, Piracicaba, Rio Claro, São Carlos, Santa Maria da Serra, São Pedro, Socorro e Valinhos (IBGE, 1983); 
- Carta de solos do Estado de São Paulo, escala de 1:500.000 (Brasil, 1960);

- Mapa pedológico do Brasil, escala de 1:1.000.000, folhas Rio de Janeiro/Vitória (Brasil, 1983);

- Banco de dados de solos da bacia do rio Piracicaba (Projeto Piracena, 1998);

- Carta de utilização da terra do Estado de São Paulo, escala de 1:250.000, folhas de Campinas, Guaratinguetá e Santos (IGC, 1980) e folhas de Bauru e São Paulo (IGC, 1981);

- Imagem de satélite Landsat 5 - TM, bandas 1, 2, 3, 4, 5 e 7 do ano de 1993 (INPE, 1993);

- Dados mensais de precipitação dos postos hidrométricos operados pelo Departamento de Águas e Energia Elétrica do Estado de São Paulo, com os dados mensais de precipitação (São Paulo, 1991b).

\subsubsection{Equipamentos}

Foram utilizados os seguintes equipamentos:

- Estação de trabalho Sun Spark-20;

- Microcomputador PC Duplo Pentium Pro 200;

- Mesa digitalizadora GTCO Digi-Pad;

- Impressora a jato de tinta HP 1600CM - PostScript.

- Sistema de Posicionamento Global - marca Garmin

\subsubsection{Programas}

Utilizaram-se os seguintes programas:

- ARC-INFO, versão 7.0.3;

- ARCVIEW, versão 2.0 . 


\subsection{Métodos}

O método adotado para estimar as perdas de solo por erosão na bacia do rio Piracicaba baseia-se na aplicação da Equação Universal de Perda de Solos por meio de técnicas de geoprocessamento (Mertes, 1997).

Para tanto, uma série de mapas temáticos (erosividade, erodibilidade, comprimento do declive, declividade, uso e cobertura do solo e práticas conservacionistas) foram criados, processados e analisados usando o SIG ARC-INFO.

Os mapas temáticos foram integrados através do SIG, gerando mapas de perdas de solo por erosão (Figura 6), que foram reclassificados em quatro categorias de riscos de erosão: baixo $\left(0-2 \mathrm{tha}^{-1}\right)$, médio $\left(2-4 \mathrm{t} \mathrm{ha}^{-1}\right)$, alto $\left(4-6 \mathrm{tha}^{-1}\right)$ e muito alto $(>6 \mathrm{t}$ ha $\left.{ }^{-1}\right)$.

Os mapas de risco de erosão dos solos da bacia do rio Piracicaba foram obtidos para os meses de janeiro e julho de 1978 e 1993, com duas práticas conservacionistas distintas: plantio morro abaixo e plantio em contorno. Os anos de 1978 e 1993 foram escolhidos por conterem as informações mais recentes disponíveis para utilização, no formato analógico e digital, respectivamente. Janeiro e julho foram selecionados por apresentarem os dados de pluviosidade mais representativos dos períodos de chuva e seca, respectivamente.

O mapa de risco de erosão do mês de janeiro de 1993, com prática de plantio em contorno, foi verificado no campo (verdade terrestre) e será comentado mais detalhadamente no ítem 3.3.2. 

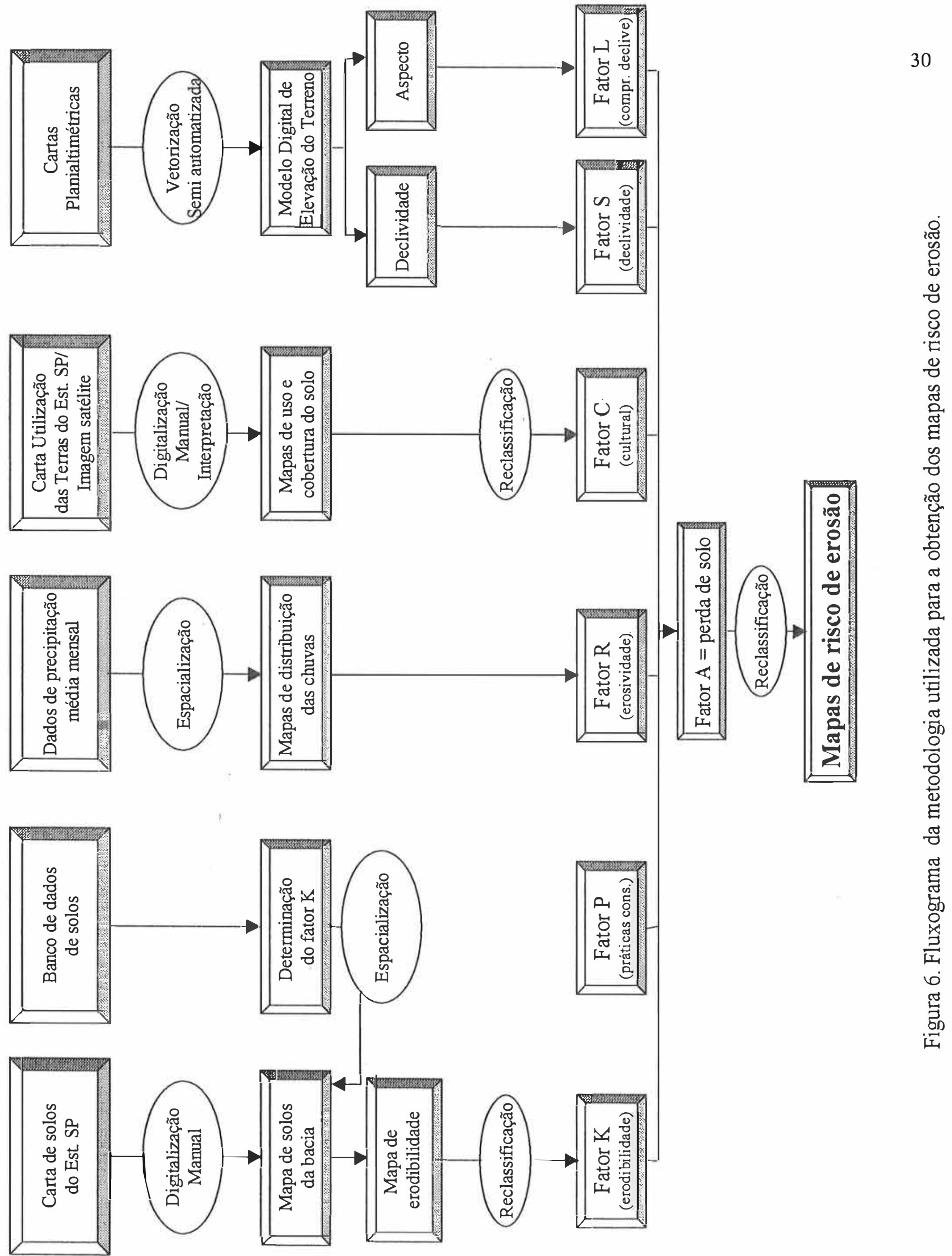


\subsubsection{Obtenção dos fatores da Equação Universal de Perda de Solo}

Os procedimentos utilizados para obtenção dos fatores necessários à estimativa das perdas de solo por erosão são descritos a seguir.

\subsubsection{Erosividade (R)}

A erosividade é um índice numérico que representa o potencial da chuva e enxurrada para provocar erosão em uma área sem proteção (Bertoni \& Lombardi Neto, 1990).

As perdas de solo provocadas por chuvas em uma área são diretamente proporcionais ao produto da energia cinética da chuva pela sua intensidade máxima em 30 minutos. Este produto é denominado índice de erosão (EI).

Para a obtenção da erosividade, que na presente pesquisa é correspondente ao EI, foram criados mapas de distribuição da precipitação. Para tal, os dados de precipitação dos meses de janeiro e julho dos anos de 1978 e 1993, foram referenciados geograficamente, associando-se a seu valor uma posição no espaço, através das coordenadas geográficas (latitude/longitude) de cada uma das 84 estações pluviométricas. Estes mapas foram gerados no SIG a partir da interpolação dos valores de precipitação mensais pelo Método do Inverso do Quadrado da Distância, tomando-se apenas as oito estações mais próximas do ponto a ser calculado, como base para a estimativa do seu valor (Pellegrino, 1995).

A relação das estações pluviométricas e suas sub-bacias (obtidos junto ao Departamento de Águas Esgoto e Energia Elétrica) é mostrada a seguir:

Sub-bacia Atibaia (D3-002, D3-069, E3-017, E3-074, E3-154, E3-247, E3-099, E3-250);

Sub-bacia Cachoeira (E3-076, E3-227, E3-229);

Sub-bacia Camanducaia (D3-023, D3-027, D3-031, D3-036, D3-042);

Sub-bacia Corumbatai (D4-012, D4-016, D4-035, D4-036, D4-043, D4-054, D4059, D4-074, D4-108, D4-109); 
Sub-bacia Jaguari (D3-009, D3-018, D3-035, D3-046, D3-052, D3-054, D3063, D3-064, D3-065, D4-052, D4-082, D4-099, D2-021, D3-070, E3-049, E3-055, E3242);

Sub-bacia Piracicaba (D4-004, D4-044, D4-056, D4-060, D4-061, D4-062, D4064, D4-079, D4-087, D4-088, D4-089, D4-092, D4-102, D4-103, D4-104, D4-111, D5062, D5-082, D5-086);

Sub-bacias Vizinhas (C4-071, D2-021, D3-008, D3-030, D4-011, D4-022, D4027, D4-032, D4-034, D4-037, D4-068, D4-069, D4-071, D4-083, D4-094, D4-098, D5044, E3-050, E3-055, E3-225, E3-230, E3-242) (São Paulo, 1991b).

A erosividade foi então calculada, aplicando-se o modelo proposto por Lombardi Neto \& Moldenhauer (1992), expresso da seguinte maneira:

$$
\mathrm{EI}=68,730\left(\mathrm{r}^{2} / \mathrm{P}\right)^{0,841}
$$

sendo:

$\mathrm{EI}=$ média mensal do índice de erosão em $\mathrm{MJ} \mathrm{mm} \mathrm{ha}^{-1} \mathrm{~h}^{-1}$;

$\mathrm{r}$ = precipitação média mensal em milímetros;

$\mathrm{P}=$ precipitação média anual em milímetros.

\subsubsection{Erodibilidade (K)}

O significado da erodibilidade do solo é diferente de erosão do solo. A intensidade de erosão de uma área qualquer pode ser influenciada mais pelo declive, características das chuvas, cobertura vegetal e manejo, do que pelas propriedades do solo. Contudo, alguns solos são mais erodíveis que outros, mesmo quando o declive, a precipitação, a cobertura vegetal e as práticas de conservação são as mesmas. Essa diferença, devido às propriedades inerentes ao solo, é referida como erodibilidade do solo (Wischmeier et al., 1971).

Para o cálculo da erodibilidade foi utilizada a equação apresentada por Denardin (1990), que se baseia no monograma de Wischmeier et al. (1971), como segue: 
$K=0,00000748(M)+0,00448059(P)-0,06311750(D M P)+0,01039567(R)$

Na qual:

$\mathrm{K}=$ valor estimado para o fator erodibilidade do solo, em $\mathrm{t} \mathrm{h} \mathrm{MJ}^{-1} \mathrm{~mm}^{-1}$;

$\mathbf{M}=$ variável adimensional calculada a partir de parâmetros granulométricos, ou seja: \% novo silte $\mathrm{x}(\%$ novo silte $+\%$ nova areia);

$\mathrm{P}=$ permeabilidade do solo conforme Wischmeier et al. (1971), no qual foram estabelecidas as seguintes classes de permeabilidade: 1 = rápida, 2 = moderada a rápida; $3=$ moderada; $4=$ lenta a moderada; $5=$ lenta; $6=$ muita lenta;

$\mathrm{DMP}=$ diâmetro médio ponderado das partículas menores que $2 \mathrm{~mm}(\mathrm{~mm})$;

$\mathrm{R}=$ relação entre teor de matéria orgânica e o teor da nova areia (MO x \% nova areia)/100

O modelo foi testado para os solos do Brasil e utiliza variáveis de análises de rotina, porém, o parâmetro " $\mathrm{M}$ " não. Para o cálculo deste, é necessário dividir a fração areia em: areia muito fina, areia fina, areia média, areia grossa e areia muito grossa. Como na base de dados disponível havia apenas a divisão areia grossa e areia fina, a equação de Denardin (1990), foi adaptada por Levy (1995). A partir desta adaptação, a fração novo silte, foi substituída pelas frações silte e areia fina e a fração nova areia, por areia grossa.

Os valores dos diâmetros médios das partículas foram obtidos a partir de Ranieri (1996), que utilizou a seguinte expressão:

$\mathrm{DMP}=\Sigma(\mathrm{Ct} \times \mathrm{Pm})$

sendo:

$\mathrm{Pm}=$ peso médio de cada classe

$\mathrm{Ct}=$ centro de cada classe textural expresso em $\mathrm{mm}$ pela escala phi.

Os valores dos diâmetros médios das classes texturais, obtidos por Ranieri (1996), encontram-se na Tabela 1. 
Tabela 1 - Diâmetro médio de cada classe textural para o cálculo do diâmetro médio ponderado das partículas.

\begin{tabular}{cc}
\hline Classe textural & Diâmetro médio (escala phi) \\
\hline Areia grossa & 0,65000 \\
Areia fina & 0,15000 \\
Silte & 0,01170 \\
Argila & 0,00024 \\
\hline
\end{tabular}

Fonte: Ranieri (1996)

O modelo matemático desenvolvido por Denardin (1990) e adaptado por Levy (1995) foi aplicado para os solos existentes na bacia do rio Piracicaba, tomando-se como base o banco de dados de solos do Projeto Piracena (Projeto Piracena, 1998). A Carta de Solos do Estado de São Paulo, na escala de 1:500.000 (Brasil, 1960) e o Mapa Pedológico do Brasil, na escala de 1:1.000.000 (Brasil, 1983) forarn digitalizados manualmente, gerando o mapa de solos da bacia do rio Piracicaba. Uma vez no formato digital, o mapa de solos da bacia foi reclassificado com os valores calculados de erodibilidade para cada unidade de mapeamento, resultando no mapa de erodibilidade dos solos da bacia.

\subsubsection{Fator topográfico (LS)}

O fator topográfico (LS) é obtido através da multiplicação do comprimento do declive (fator L) pela declividade (fator S) (Bertoni \& Lombardi Neto, 1990). Foi calculado utilizando-se a metodologia descrita por Hickey et al. (1994), que consiste em gerar um mapa de declividade e de comprimento de declive, a partir do Modelo Digital de Elevação do Terreno (MDET). A equação utilizada para este cálculo é expressa da seguinte forma: 
Fator $\operatorname{LS}=(\lambda / 22,3)^{t}\left(65,41 \operatorname{sen}^{2} \beta+4,56 \operatorname{sen} \beta+0,065\right)$

$\mathrm{t}=0,5$ se declive $\beta>3^{\circ} ; \mathrm{t}=0,4$ se declive $1,7^{\circ}<\beta<3^{\circ} ; \mathrm{t}=0,3$ se declive $0,6^{\circ}$ $<\beta<1,7^{\circ}$ et $=0,2$ se declive $\beta<0,6^{\circ}$.

sendo:

$\lambda=$ comprimento de declive acumulado;

$\beta=$ ângulo da declividade morro abaixo;

$\mathrm{t}$ = inclinação da variável contingencial.

O MDET foi gerado através da interpolação (por rede de triangulação irregular) das curvas de nível equidistantes 20 metros e reamostradas para 30 metros. A entrada dos dados das curvas de nível das 37 cartas planialtimétricas na escala de 1:50.000 (IBGE, 1983) foi realizada através da vetorização semi-automatizada (Ballester, 1996).

O fator topográfico é adimensional e para efeito deste trabalho, foi reclassificado em quatro grupos: 0-2; 2-4; 4-10 e maior que 10.

\subsubsection{Fator cultural (C)}

O fator cultural ou uso e manejo do solo é a relação esperada entre as perdas de solo de um terreno cultivado em dadas condições e as perdas correspondentes de um terreno mantido continuamente descoberto (Bertoni \& Lombardi Neto, 1990).

Para o estabelecimento dos diferentes valores do fator cultural, foi necessário gerar mapa de uso e cobertura do solo para a bacia do rio Piracicaba para o ano de 1978.

Para gerar o mapa de uso em 1978, foram digitalizadas manualmente, as Cartas de Utilização da Terra do Estado de São Paulo, escala de 1:250.000, folhas de Campinas, Guaratinguetá, Santos, São Paulo e Bauru, do Instituto Geográfico e Cartográfico do Estado de São Paulo (IGC, 1980; IGC, 1981).

Para o ano de 1993, utilizou-se o mapa de uso e cobertura do solo da bacia. Este mapa foi gerado pela interpretação (classificação supervisionada - máxima verossimilhança) da imagem de satélite Landsat 5 sensor TM bandas 1, 2, 3, 4, 5 e 7 
adquiridas junto ao Instituto Nacional de Pesquisas Espaciais (INPE) em São José dos Campos. O mapa de uso e cobertura do solo em 1993 possui um indicador de qualidade de $75 \%$ (Ballester, 1996).

Após as análises dos padrões de uso e ocupação do solo na bacia para os anos de 1978 e 1993, foram estabelecidos os valores de C, segundo Bertoni \& Lombardi Neto (1990) e Castro (1992). Os diferentes usos e coberturas dos solos da bacia e os respectivos valores atribuídos ao fator $\mathrm{C}$ são apresentados na Tabela 2 .

Tabela 2 - Valores de $\mathrm{C}$ correspondentes às diferentes categorias de uso e cobertura do solo observadas na bacia do rio Piracicaba.

\begin{tabular}{lc}
\hline Uso e cobertura do solo & Fator C \\
\hline Cana-de-açúcar & $0,1124^{1}$ \\
Citros & $0,1350^{1}$ \\
Pastagem & $0,0100^{1}$ \\
Cultura Annual & $0,0827^{1}$ \\
Cultura Perene (café) & $0,1350^{1}$ \\
Vegetação Nativa & $0,0004^{1}$ \\
Silvicultura & $0,0470^{1}$ \\
Urbanização & $0,0300^{2}$ \\
Outros usos & $0,0300^{2}$ \\
Água & $0{ }^{1}$ \\
\hline Fonte: ${ }^{\top}$ Bertoni \& Lombardi Neto $(1990)$ \\
${ }^{2}$ Castro (1992)
\end{tabular}

Além dos mapas de uso e cobertura do solo para os anos de 1978 e 1993, foram realizadas simulações, onde as áreas ocupadas por pastagem foram substituídas por cana-de-açúcar, silvicutura e vegetação nativa. 


\subsubsection{Práticas conservacionistas $(\mathrm{P})$}

O fator $\mathrm{P}$ é a relação entre a intensidade de perdas de solo com determinada prática conservacionista e aquelas quando a cultura está plantada no sentido do declive (morro abaixo). As práticas mais comuns são plantio em contorno, plantio em faixas de contorno, alternância de capinas etc.

Para a bacia do rio Piracicaba, foram simuladas duas situações distintas. Em um primeiro caso, considerou-se o valor de P, para todas as culturas existentes na bacia, como sendo igual a 0,5 , que corresponde à prática de plantio em contorno. Em uma segunda situação, o valor de $\mathrm{P}$ foi considerado igual a 1,0 , correspondente à prática de plantio morro abaixo.

\subsubsection{Verificação no campo do mapa de risco de erosão}

Os mapas de risco de erosão dos solos da bacia do rio Piracicaba, gerados através de técnicas de geoprocessamento, precisavam ser verificados no campo (verdade terrestre).

Para realizar essa verificação, contou-se com o auxílio do Prof. Dr. Eric Roose, pesquisador do "Institut Français de Recherche Scientifique Pour Le Développement en Coopération" (ORSTOM, Montpellier, França) especialista em conservação do solo e da água, que durante três semanas do mês de outubro de 1998, discutiu e orientou as atividades de campo.

O mapa de risco de erosão para o mês de janeiro de 1993 com prática de plantio em contorno foi o escolhido para ser verificado no campo. Sua escolha se justifica pelo fato desse mapa refletir de forma mais aproximada, as condições da época em que se realizou a verificação no campo (mesmo período hidrológico - época chuvosa) e por apresentar o tipo de prática conservacionista predominante na bacia do rio Piracicaba.

Durante dez dias $(5,7,8,9,13,14,16,17,20$ e 23 de outubro de 1998), foram analisadas 26 áreas distintas dentro da bacia. Em cada uma delas, foram observados os seguintes aspectos: tipologia das formas de erosão em relação à paisagem, tipos de solo, 
estado da superficie, uso e cobertura do solo, capacidade de infiltração da água no solo e análise visual da carga de sedimentos encontrada nos rios.

A metodologia adotada para estimar a erosão laminar baseou-se na avaliação da porcentagem da superfície do solo protegida da agressividade das gotas de chuva, usando o método dos pontos em quadrado (Roose, 1996).

$\mathrm{Na}$ estimava da erosão linear, avaliou-se o risco potencial de ocorrência de escoamento superficial, medindo-se a capacidade de infiltração da água na superfície dos solos (método do monocilindro) e avaliar as condições da superfície do solo (compactada ou livre para a infiltração da água no solo ou com a presença de uma fina crosta endurecida formada pelo impacto das gotas de chuva e pela enxurrada) (Roose et al., 1993).

As classes de risco de erosão obtidas através do mapa (risco baixo, médio, alto e muito alto) correspondem, respectivamente, as classes R1, R2, R3 e R4 obtidas no campo, que são definidas a seguir (Roose, 1996):

\section{Risco I: Erosão laminar}

Erosão devida ao impacto das gotas de chuva sobre toda a superficie exposta do solo. Erosão relativamente baixa em volume, alcançando cerca de $15 \mathrm{t} \mathrm{ha}^{-1} \mathrm{ano}^{-1}$ para uma densidade aparente de $1,5 \mathrm{~g} \mathrm{~cm}^{-3}$. Entretanto, apresenta seletividade de partículas finas e leves como matéria orgânica, argilas e limo $(<50 \mu \mathrm{m})$. Isso ocorre pelo fato da lâmina de água corrente na superfície do solo encontrar uma forte resistência à aceleração (friç̧ão em torrões, pedregulhos, raízes superficiais e caules) e sua baixa velocidade impede-a de transportar areia grossa e cascalho de mais de $5 \mathrm{~mm}$.

Indicadores no campo: crostas de compactação e de sedimentação, traços marcados por enxurradas, regiões com o predomínio de areia grossa lavada, microfalésias etc. 


\section{Risco 2: Erosão em sulcos (profundidade $H<10 \mathrm{~cm}$ )}

As enxurradas concentradas possuem alta velocidade e energia própria para escavar no solo pequenos canais de menos de $10 \mathrm{~cm}$ de profundidade, onde todos materiais são depositados, incluindo seixos de até $3 \mathrm{~cm}$. É um sinal de aumento excessivo da enxurrada provocada por um forte impacto das chuvas criando uma crosta impermeável e resistente, sobre um material desagregado (freqüentemente pouco coeso, como ocorre logo após um preparo de solo por gradagem). O volume erodido compreende a erosão em camada sobre toda superficie nua do solo mais o volume da cavidade (sulco) deixada pela enxurrada concentrada. As perdas de solo podem chegar a $100 \mathrm{t} \mathrm{ha}^{-1} \mathrm{ano}^{-1}$ (Roose, 1996).

Indicadores: crostas de impacto, compressão, cursos de areia e seixos, sulcos de alguns centímetros, depósitos selecionados nos sulcos (mudanças de encostas ou de rugosidade do solo).

\section{Risco 3: Erosão em sulcos profundos $(H<30 \mathrm{~cm})$}

Enxurradas muito fortes cizalham profundamente o horizonte trabalhado, mas no qual a profundidade é limitada pelo fundo do sulco (ou um horizonte B mais coeso). Os processos são os mesmos do ítem anterior, mas a intensidade é notadamente mais forte. Estes sulcos podem agora ser desfeitos por técnicas culturais, mas deixam uma ligeira concavidade na vertente que servirá de dreno cada vez mais profundo para as águas que escorrem ao longo dos traços deixados pelos implementos agrícolas no solo.

Indicadores: sulcos profundos, concentração lateral de águas não infiltradas entre as linhas de plantio, torrões e compressões abundantes, depósitos grosseiros no sopé das encostas.

\section{Risco 4: Voçorocas de até $100 \mathrm{~cm}$ de profundidade}

Sobre as encostas inclinadas (> $20 \%$ de declividade), vertentes côncavas, e estradas e caminhos de concentração de águas superficiais (rochas expostas, solos pouco profundos como os litossolos ou heterogêneos como os solos podzólicos), o fluxo concentrado de água desenvolve uma energia tal que a enxurrada sulca o solo até o 
horizonte B ou C. Os cortes nos barrancos podem ser verticais em forma de "U" se o material for heterogêneo ou em forma de "V" nos argilitos, material orgânico, xistos que se alteram rapidamente.

Indicadores: voçorocas, ravinas de menos de $1 \mathrm{~m}$ de profundidade, numerosos sulcos concentradores de água nas encostas côncavas, transferência de sedimentos até os rios (deposição de areia fina).

Os dados coletados no campo foram espacializados usando pontos de controle obtidos via GPS (Global Positioning System), gerando um novo plano de informação. Posteriormente, este plano de informação foi sobreposto ao mapa de risco de erosão, permitindo uma comparação entre os resultados obtidos pelos dois métodos. 


\section{RESULTADOS E DISCUSSÃO}

Os resultados e discussão serão apresentados em três partes. Na primeira, serão apresentadas as bases necessárias para o mapeamento do risco de erosão. A seguir, serão apresentados os mapas de risco de erosão dos solos da bacia do rio Piracicaba, para os meses de janeiro e julho de 1978 e 1993 e com fatores de práticas conservacionistas distintos. Na última parte, serão apresentados os resultados da validação no campo, do mapa de risco de erosão para o mês de janeiro de 1993 com prática de plantio em contorno.

\subsection{Bases necessárias para o mapeamento do risco de erosão}

4.1.1 Mapa de Solos e valores de erodibilidade calculados para os solos da bacia do rio Piracicaba

\subsubsection{Mapa de solos da bacia}

O mapa de solos da bacia do rio Piracicaba (Figura 7), é constituído por vinte e duas unidades de mapeamento, representadas pelas classes dos Latossolos, Podzólicos, Podzolizados, Litossolos, Regossolos, Hidromórifcos, Aluvionais e Mediterrâneos.

A porcentagem de ocupação de cada unidade mapeada, está representada na Figura 8. Os Latossolos Vermelho-Amarelo, Podzólicos Vermelho-Amarelo e Podzólicos Vermelho-Amarelo variação Laras são os mais expressivos em termos de área e correspondem aproximadamente a um terço de toda a área mapeada. Os 
Regossolos, Podzolizados variação Marília, Latossolos Vermelho-Amarelo intergrade Podzólico Vermelho-amarelo e os Mediterrâneos Vermelho-Amarelo são os menos expressivos, onde cada unidade ocupa menos de $1 \%$ da área mapeada (Figura 8).

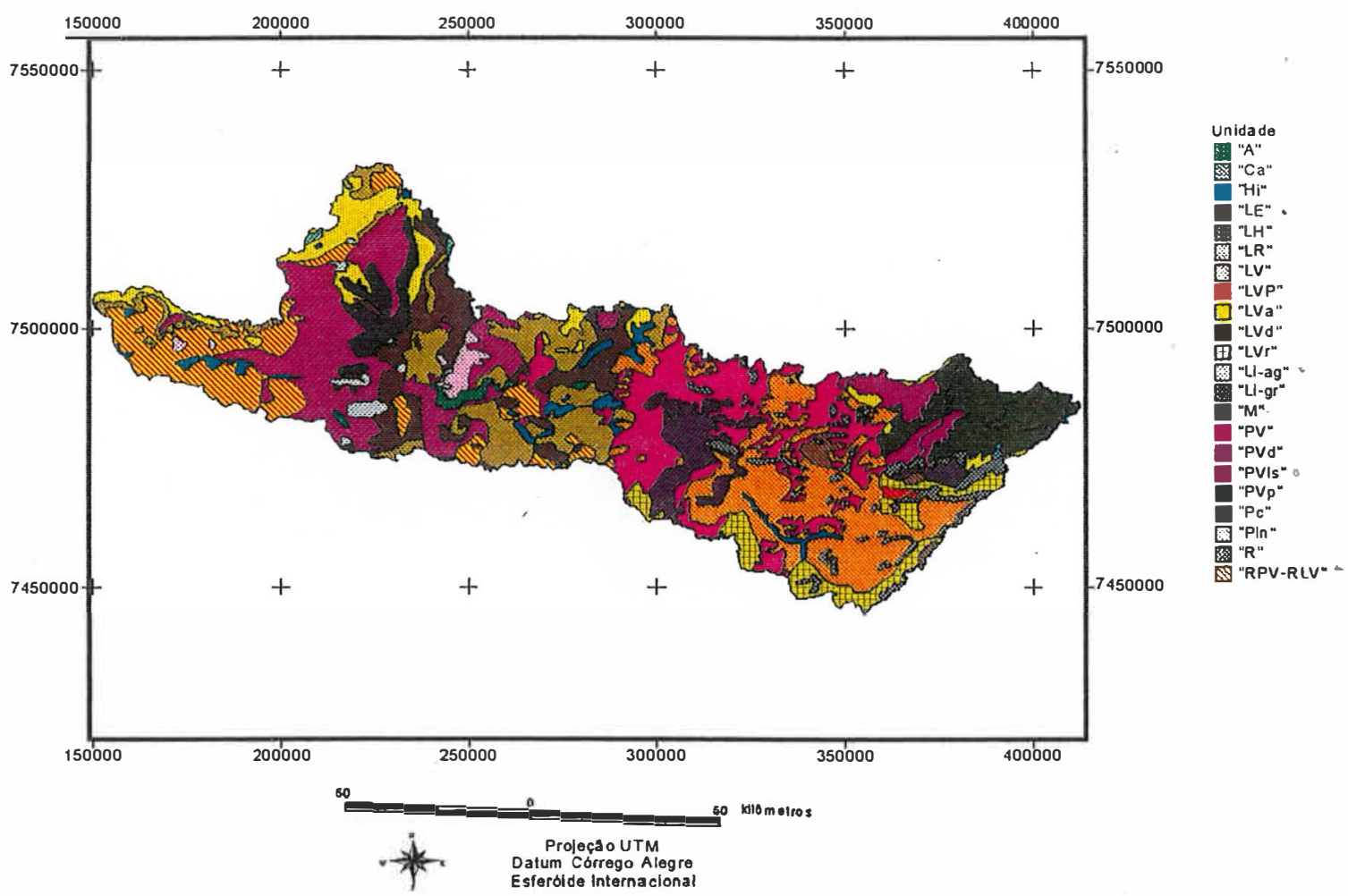

Figura 7. Mapa de solos da bacia do rio Piracicaba.

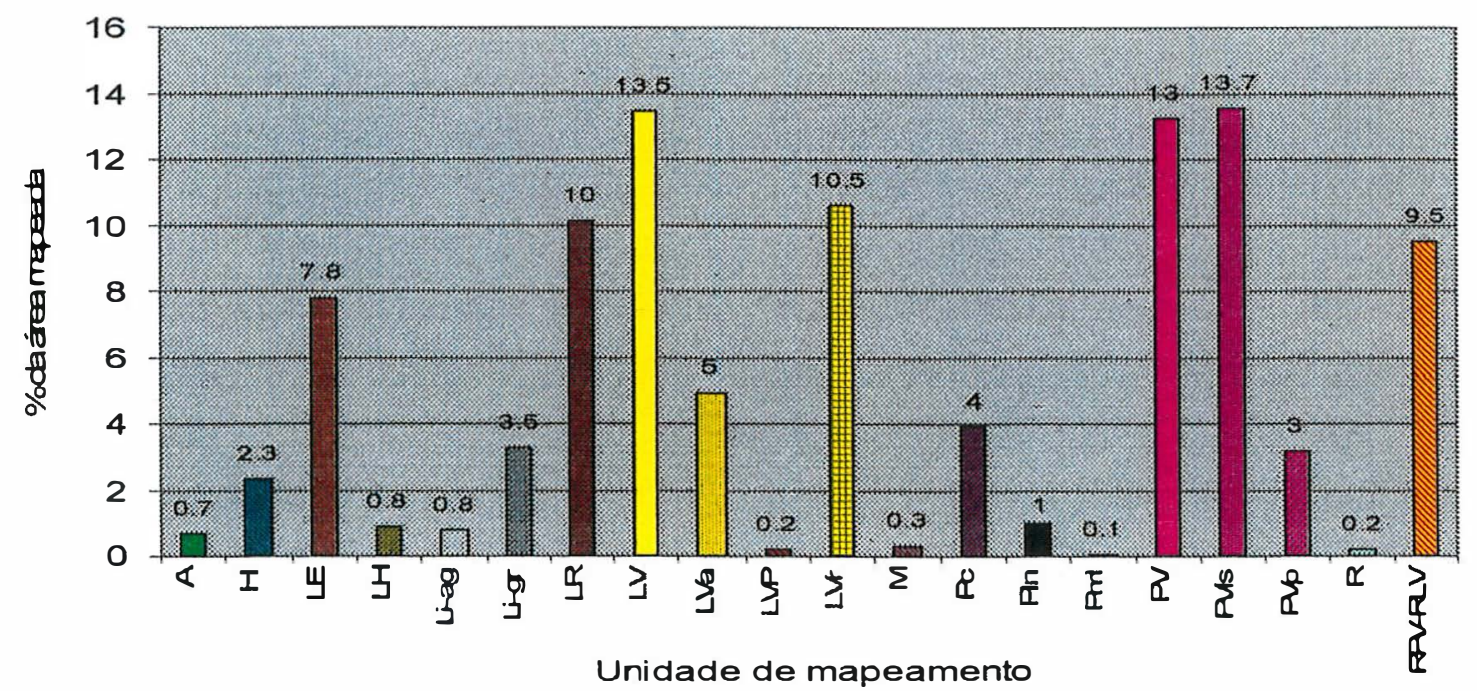

Figura 8. Distribuição das frequências das unidades de mapeamento dos solos da bacia do rio Piracicaba. 


\subsubsection{Valores de erodibilidade calculados para os solos da bacia do Piracicaba}

Os valores de erodibilidade calculados para cada unidade de mapeamento da Carta de Solos do Estado de São Paulo (Brasil, 1960), através da aplicação do modelo matemático desenvolvido por Denardin (1990) e adaptado por Levy (1995), são apresentados na Tabela 3 .

Tabela 3 - Valores de erodibilidade para os solos da bacia do rio Piracicaba.

\begin{tabular}{|c|c|}
\hline Unidade de mapeamento & Fator $\mathbf{K}\left(\mathrm{t} \mathrm{h} \mathrm{Mj} \mathrm{j}^{-\mathrm{I}} \mathrm{mm}^{-\mathrm{I}}\right)$ \\
\hline LV & 0,0189 \\
\hline LVa & 0,0087 \\
\hline $\mathrm{LVr}$ & 0,0313 \\
\hline $\mathrm{LVp}$ & 0,0195 \\
\hline LH & 0,0163 \\
\hline LE & 0,0156 \\
\hline LR & 0,0174 \\
\hline $\mathrm{R}$ & 0,0163 \\
\hline RPV-RLV & 0,0353 \\
\hline PV & 0,0290 \\
\hline $\mathrm{Pc}$ & 0,0307 \\
\hline PVls & 0,0527 \\
\hline$P V p$ & 0,0409 \\
\hline Pml & 0,0639 \\
\hline Pln & 0,0521 \\
\hline Li-gr & 0,0455 \\
\hline Li-ag & 0,0411 \\
\hline $\mathrm{Hi}$ & 0,0681 \\
\hline M & 0,0467 \\
\hline A & 0,0681 \\
\hline
\end{tabular}


sendo:

$\mathrm{LV}=$ Latossolo Vermelho-Amarelo Orto

$\mathrm{LVa}=$ Latossolo Vermelho-Amarelo fase arenosa

$\mathrm{LVr}=$ Latossolo Vermelho-Amarelo fase rasa

LVP = Latossolo Vermelho-Amarelo intergrade Podzólico Vermelho-Amarelo

LH = Latossolo Vermelho-Amarelo Húmico

LE $\doteq$ Latossolo Vermelho-Escuro Orto

LR $=$ Terra Roxa Legítima

$\mathrm{R}=$ Regosol

RPV-RLV = Regosol intergrade Podzólico Vermelho-Amarelo intergrade

Latossolo Vermelho-Amarelo

PV = Podzólico Vermelho-Amarelo Orto

$\mathrm{Pc}=$ Podzolizados com cascalho

PVls = Podzólico Vermelho-Amarelo variação Laras

PVp = Podzólico Vermelho-Amarelo variação Piracicaba

$\mathrm{Pml}=$ Podzolizados variação Marília

$\mathrm{Pln}=$ Podzolizados variação Lins

Li-gr $=$ Litosol fase substrato granito-gnaisse

Li-ag $=$ Litosol fase substrato folhelho-argilito

$\mathrm{Hi}=$ Hidromórficos

M = Mediterrâneo Vermelho-Amarelo

$\mathrm{A}=$ Aluvionais 


\subsubsection{Mapa de Uso e Cobertura do Solo para os anos de 1978 e 1993}

Os mapas de uso e cobertura do solo da bacia do rio Piracicaba para os anos de 1978 e 1993 estão compostos por dez diferentes classes, tais como: áreas com vegetação nativa, seis classes agrossilvopastoris (cana-de-açúcar, citros, culturas anuais, culturas perenes, pastagem e silvicultura), áreas urbanas e industriais e cobertas por água (Figuras 9 e 10).

Ficou evidente que, em 1978, mais de $50 \%$ da área mapeada da bacia era coberta por pastagem. A segunda ocupação mais expressiva era a cana-de-açúcar, com $20 \%$ da área total. Citros, culturas anuais e silvicultura representavam juntas, aproximadamente $15 \%$ e a vegetação nativa cerca de $7 \%$ da área mapeada. A cultura perene estava relacionada principalmente com a cultura do café e ocupava uma área de aproximadamente $1 \%$ (Figura 11). Pode-se verificar também que, na região de maior desenvolvimento urbano (ou seja, próximo às cidades de Campinas, Piracicaba, Americana, Limeira e Rio Claro) ocorre a predominância das culturas de cana-de-açúcar e citros. Já na região próxima às nascentes dos rios que compõem a bacia do rio Piracicaba, havia uma ocupação mais expressiva da pastagem (Figura 9).

Para o ano de 1993 observa-se que mais de $35 \%$ da área mapeada da bacia é coberta por cana-de-açúcar. Áreas cobertas por pastagem ocupam aproximadamente 24 $\%$ do total. Citros e culturas anuais representam juntas aproximadamente $15 \%$, silvicultura $16 \%$ e a vegetação nativa somente $3,5 \%$ (Figura 11). 


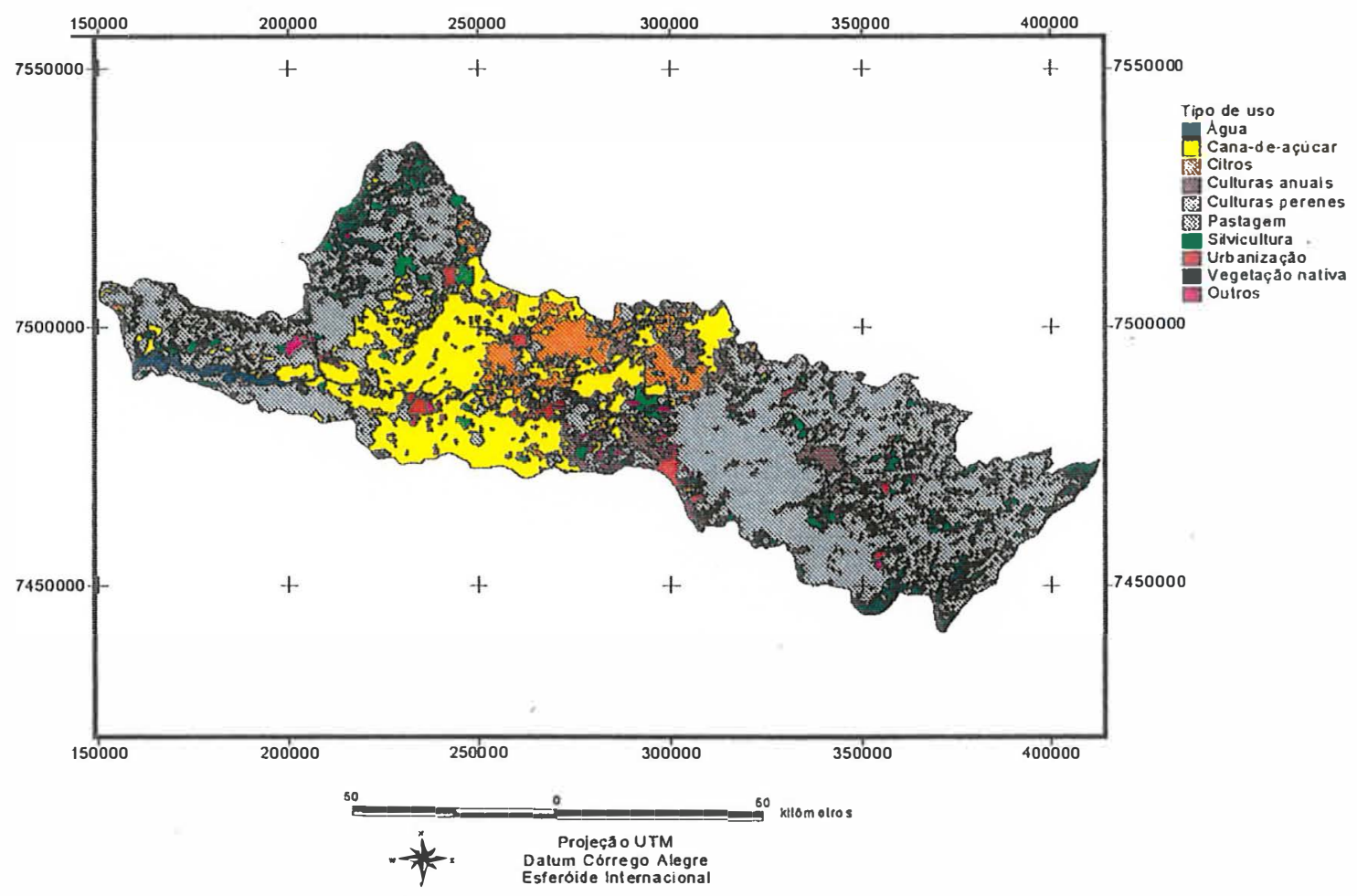

Figura 9. Mapa de uso e cobertura do solo do ano 1978.

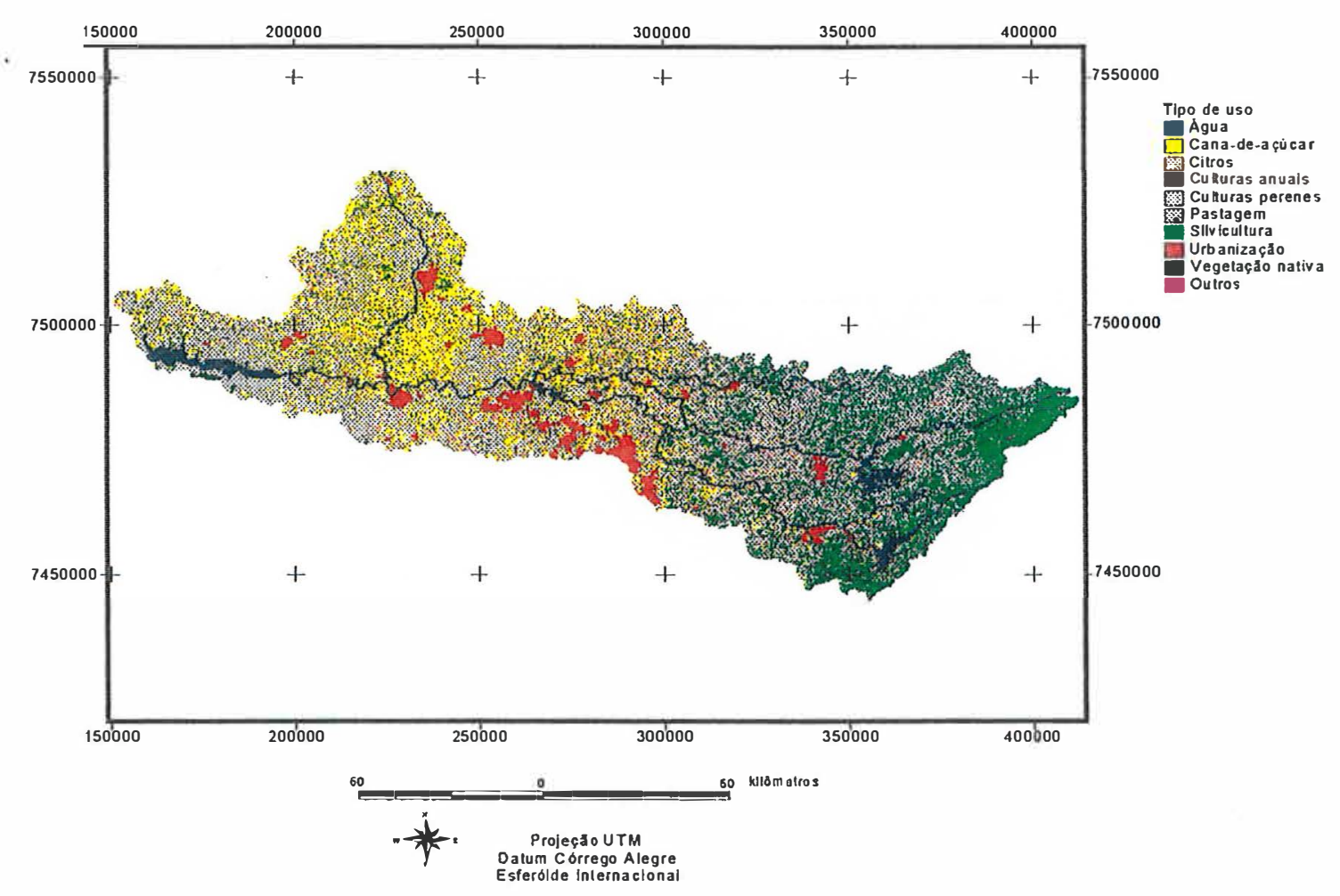

Figura 10. Mapa de uso e cobertura do solo em 1993. 
Comparando os dados obtidos para os anos de 1978 e 1993, observa-se que a bacia como um todo sofreu pequenas modificações em termos de uso do solo entre as décadas de 80 e 90. As principais mudanças observadas são a expansão das áreas de cultivo de cana-de-açúcar e de silvicultura, com uma diminuição das pastagens e o crescimento dos centros urbanos (Figura 11), concordando com observações de Borges et al. (1993) e Fiorio (1998) que avaliaram o uso da terra na região de Piracicaba.

O aumento observado na área coberta por água, resulta do fechamento da Represa no rio Jaguarí que ocorreu neste período. Fiorio (1998), por sua vez, verificou uma diminuição na dimensão dos açudes de água em uma microbacia da região de Piracicaba, concluindo ter sido motivada pelo assoreamento provocado pelo cultivo de cana-de-açúcar em solos inadequados.

A obtenção do uso da terra por imagens orbitais como base para o desenvolvimento de mapas de risco de erosão também foi realizado por De Lima et al. (1992) e Balstroem (1994), demonstrando ser um método satisfatório.

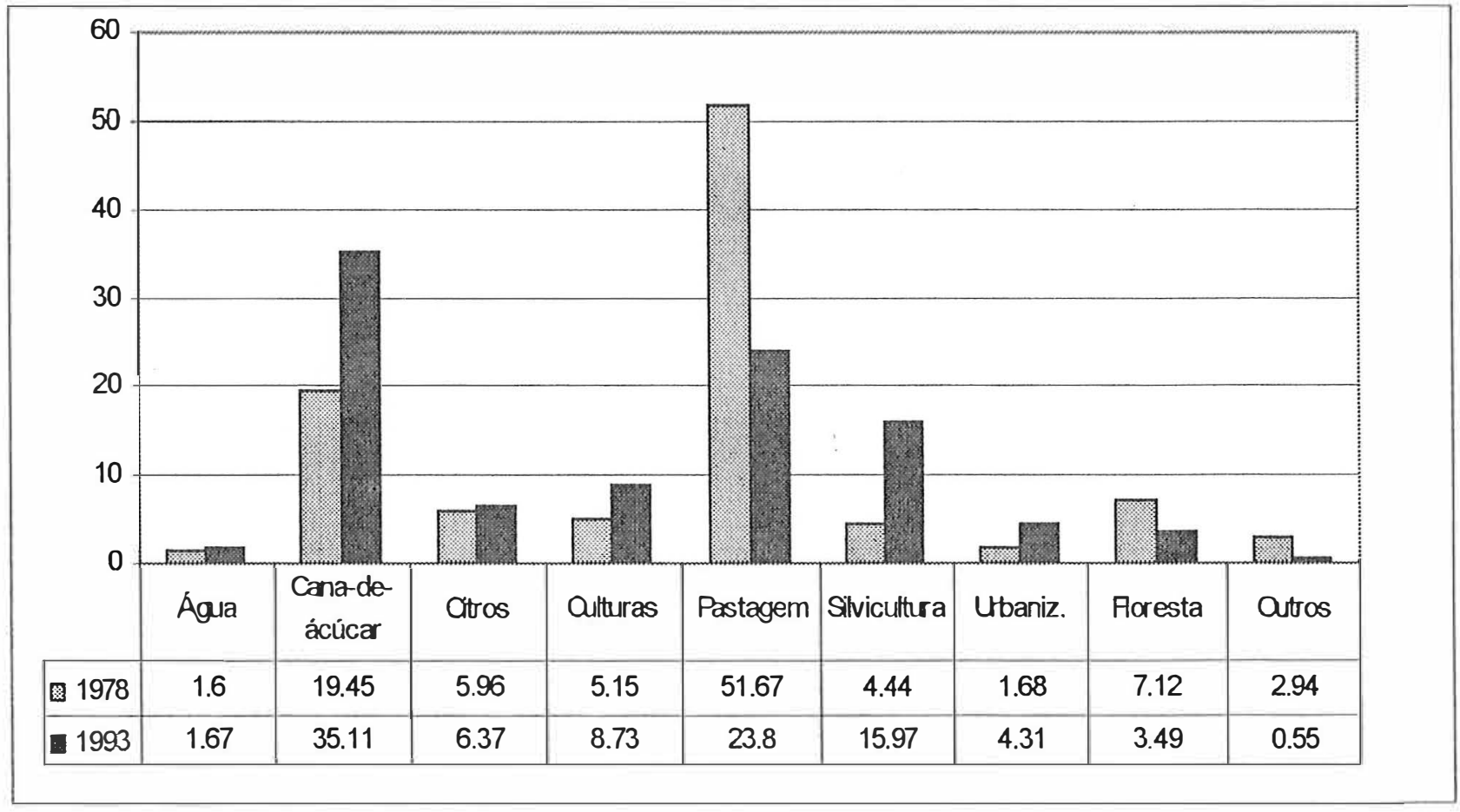

Figura 11. Porcentagem da área coberta por cada tipo de uso da terra nos anos de 1978 e 1993. 


\subsubsection{Mapa do fator topográfico (LS)}

A Figura 12 apresenta o mapa do fator topográfico (LS) na bacia do rio Piracicaba. Uma análise comparativa das cores, indica que as classes mais expressivas em termos de área são as de 0-2 e maior que 10. Pode-se observar, que a área da bacia possui duas regiões distintas, concordando com as informações de São Paulo (1991a).

A primeira região corresponde à depressão periférica, onde predominam valores de 0-2. O relevo é do tipo colinoso, predominando declividades pouco acentuadas (menores que $10 \%$ ), com cotas variando de 700 metros até pouco abaixo de 500 metros e drenagem de média a baixa densidade. No segundo setor geomorfológico, Planalto Ocidental, predominam os valores do fator topográfico maiores que 10. Este setor estende-se desde as cabeceiras até a porção média, apresentando um relevo montanhoso, com declividade média alta (acima de $15 \%$ ) e cotas variando de 2000 metros na cabeceira até 600 metros nos fundos dos vales.

O cálculo do LS através de um algoritmo computacional facilitou a integração das informações em um SIG, concordando com Desmet \& Govers (1996).

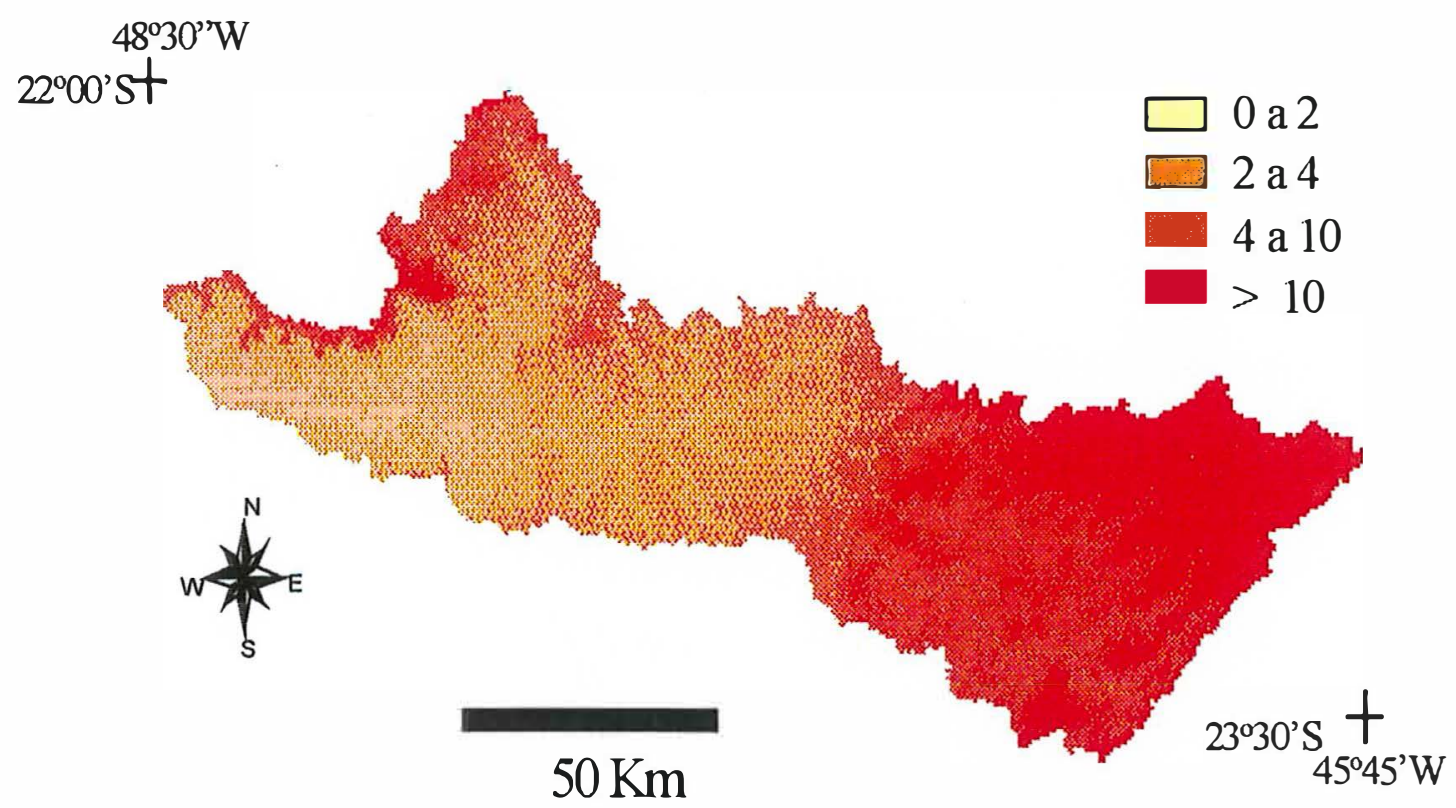

Figura 12. Mapa do fator topográfico da bacia do rio Piracicaba. 


\subsubsection{Mapas dos Índices de Erosão (EI)}

Os mapas de distribuição dos índices de erosão para os meses de janeiro e julho do ano de 1978 (Figuras 13 e 14) e de janeiro e julho de 1993 (Figuras 15 e 16) foram gerados a partir da distribuição das chuvas e podem ser observados a seguir.

Independentemente do ano, no mês de janeiro, a distribuição espacial das classes dos índice de erosão é mais homogênea do que no mês de julho. No mês de janeiro há uma dominância da classe compreendida entre 100 e 200. Já para o mês de julho, a distribuição entre as categorias é mais heterogênea, entretanto ocorre predominância das categorias 8 a 25 e 25 a 100 . 


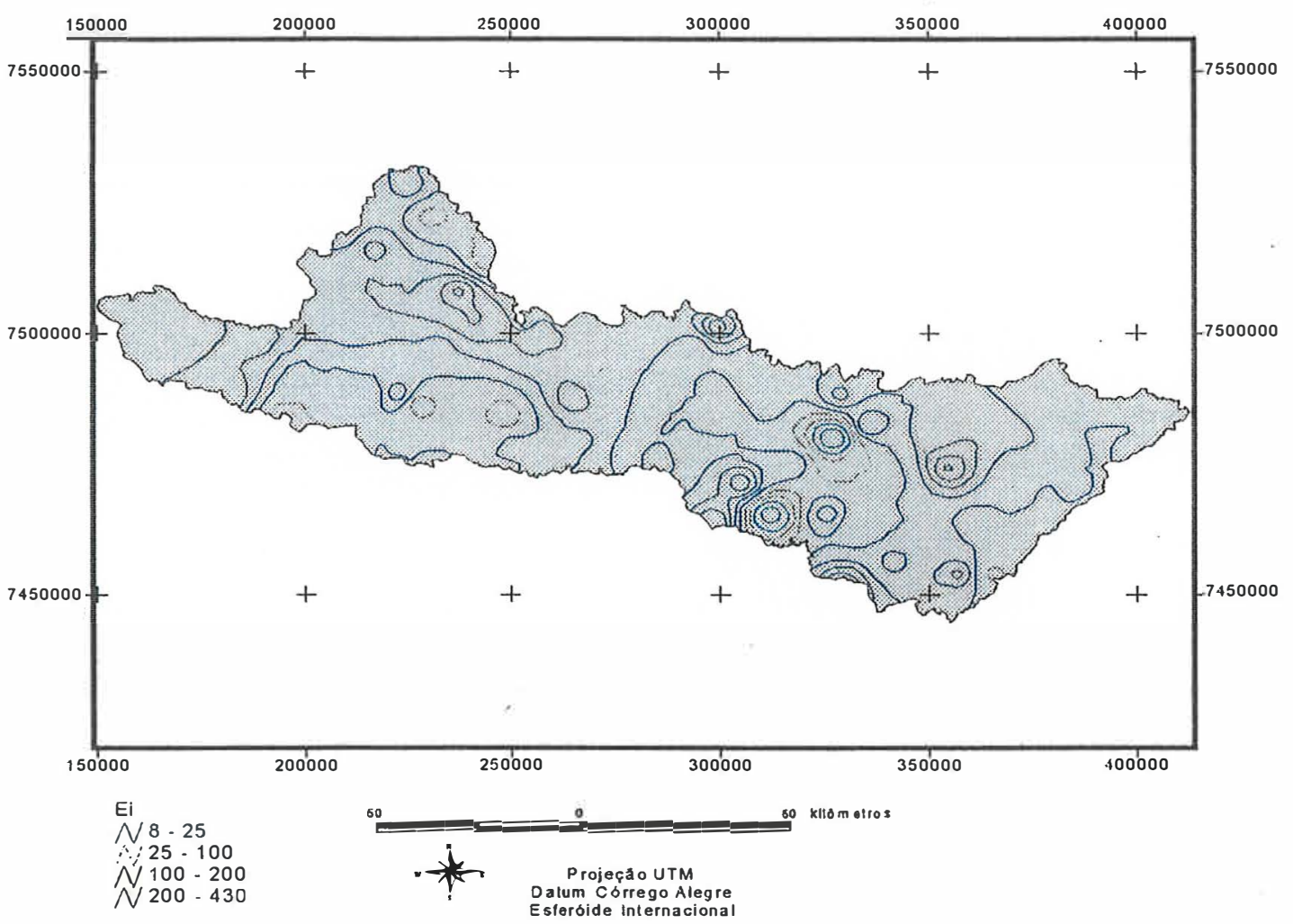

Figura 13. Mapa dos índices de erosão da bacia do rio Piracicaba em janeiro de 1978.

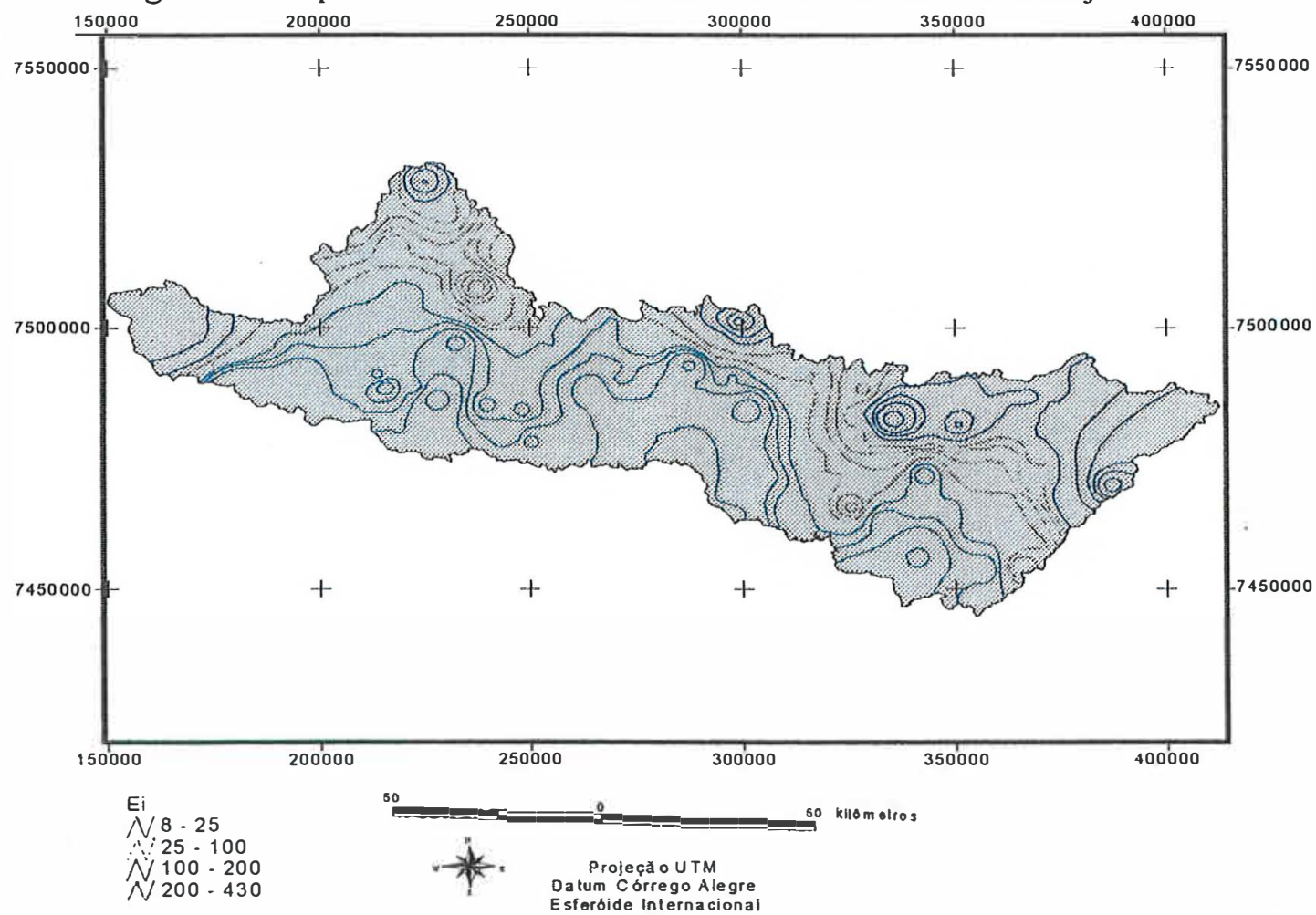

Figura 14. Mapa dos índices de erosão da bacia do rio Piracicaba em julho de 1978. 


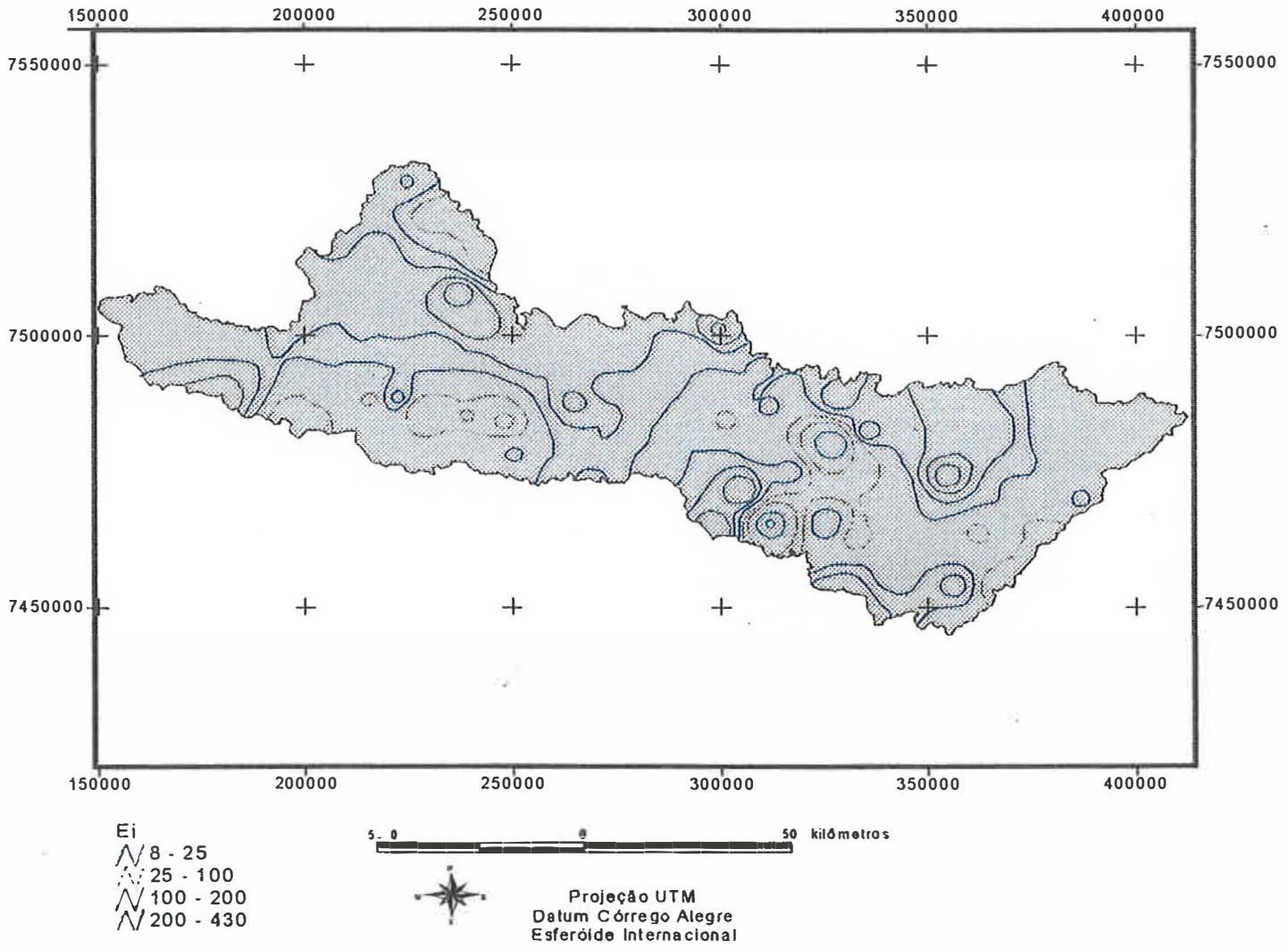

Figura 15. Mapa dos índices de erosão da bacia do rio Piracicaba em janeiro de 1993.

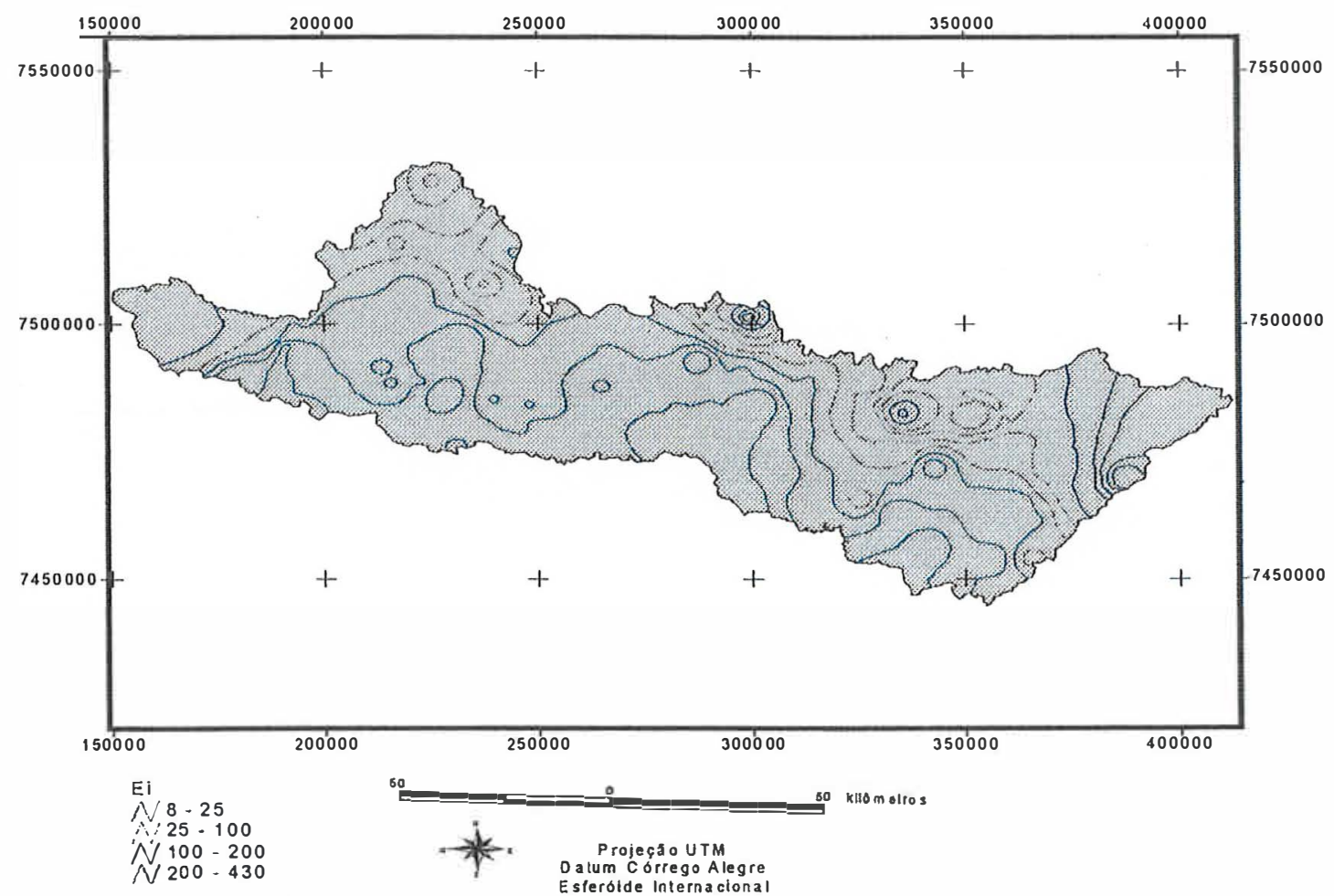

Figura 16. Mapa dos índices de erosão da bacia do rio Piracicaba em julho de 1993. 


\subsection{Mapas de risco de erosão}

\subsubsection{Mapas de risco de erosão para o ano de 1978}

Os mapas de riscos de erosão para o ano de 1978 serão apresentados para duas épocas distintas do ciclo hidrológico: máxima pluviosidade (mês de janeiro) e mínima pluviosidade (mês de julho). Em cada uma dessas épocas efetuaram-se as estimativas para duas práticas conservacionistas contrastantes: plantio morro abaixo e plantio em contorno.

No período chuvoso (Figuras 17 e 18), a maior parte da área da bacia está enquadrada no risco de erosão baixo, para as duas práticas conservacionistas. O risco de erosão com plantio morro abaixo (Figura 18) é sensivelmente maior quando comparado com o plantio em contorno (Figura 17).

A constatação desta afirmativa pode ser observada na Tabela 4, na qual o risco de erosão baixo para o plantio morro abaixo é de $94,83 \%$ enquanto que para o plantio em contorno o valor é superior $(97,56 \%)$.

A análise das figuras de riscos de erosão para o mês de julho com prática de plantio morro abaixo (Figura 20) e plantio em contorno (Figura 19), evidenciam as mesmas tendências dos riscos de erosão observados para o período de chuva.

Pode-se constatar pela Tabela 4, que as áreas com risco de erosão baixo na época da seca, foram maiores $(99,55 \%)$ do que as áreas de risco apresentado na época da chuva $(97,56 \%)$. Pode-se verificar também, que nas áreas com prática de plantio morro abaixo os riscos de erosão foram, independentemente da época, maiores (cerca de $4 \%$ ) em relação de plantio em contorno (aproximadamente $2 \%$ ). Através dessa comparação constata-se que a erosão é influenciada de maneira direta por fatores antrópicos, como a prática conservacionista.

As Figuras 21e, f e g e 22e, f e g apresentam os riscos de erosão que poderiam ocorrer se a área ocupada por pastagem em 1978 fosse transformada em cultivo de canade-açúcar, silvicultura e vegetação nativa, respectivamente. A vegetação nativa é a cobertura do solo que propiciou o menor risco de erosão. A área de pastagem, 
hipoteticamente transformada em cana-de-açúcar foi a que apresentou o maior risco de erosão. A silvicultura ocupa uma posição intermediária (Tabela 5).

Tabela 4. Distribuição percentual das áreas de risco de erosão na bacia do rio Piracicaba, para os meses de janeiro e julho de 1978 com práticas de plantio morro abaixo e em contorno.

\begin{tabular}{|c|c|c|c|c|}
\hline \multirow[t]{2}{*}{ Risco } & Janeiro & Julho & Janeiro & Julho \\
\hline & \multicolumn{2}{|c|}{ Plantio morro abaixo } & \multicolumn{2}{|c|}{ Plantio em contorno } \\
\hline Baixo & 94,83 & 98,64 & 97,56 & 99,55 \\
\hline Médio & 3,53 & 0,91 & 1,56 & 0,27 \\
\hline Alto & 1,48 & 0,37 & 0,78 & 0,16 \\
\hline Muito Alto & 0,17 & 0,07 & 0,11 & 0,02 \\
\hline
\end{tabular}

Tabela 5. Distribuição percentual das áreas de risco de erosão na bacia do rio Piracicaba, para os diferentes usos e coberturas do solo, para o mês de janeiro de 1978 com prática de plantio em contorno.

\begin{tabular}{lcccc}
\hline Risco & Vegetação Nativa & Pastagem & Silvicultura & Cana-de-açúcar \\
\hline Baixo & 98,13 & 97,56 & 93,21 & 87,15 \\
Médio & 1,15 & 1,56 & 4,02 & 6,17 \\
Alto & 0,61 & 0,78 & 2,52 & 5,88 \\
Muito alto & 0,10 & 0,11 & 0,25 & 0,79 \\
\hline
\end{tabular}




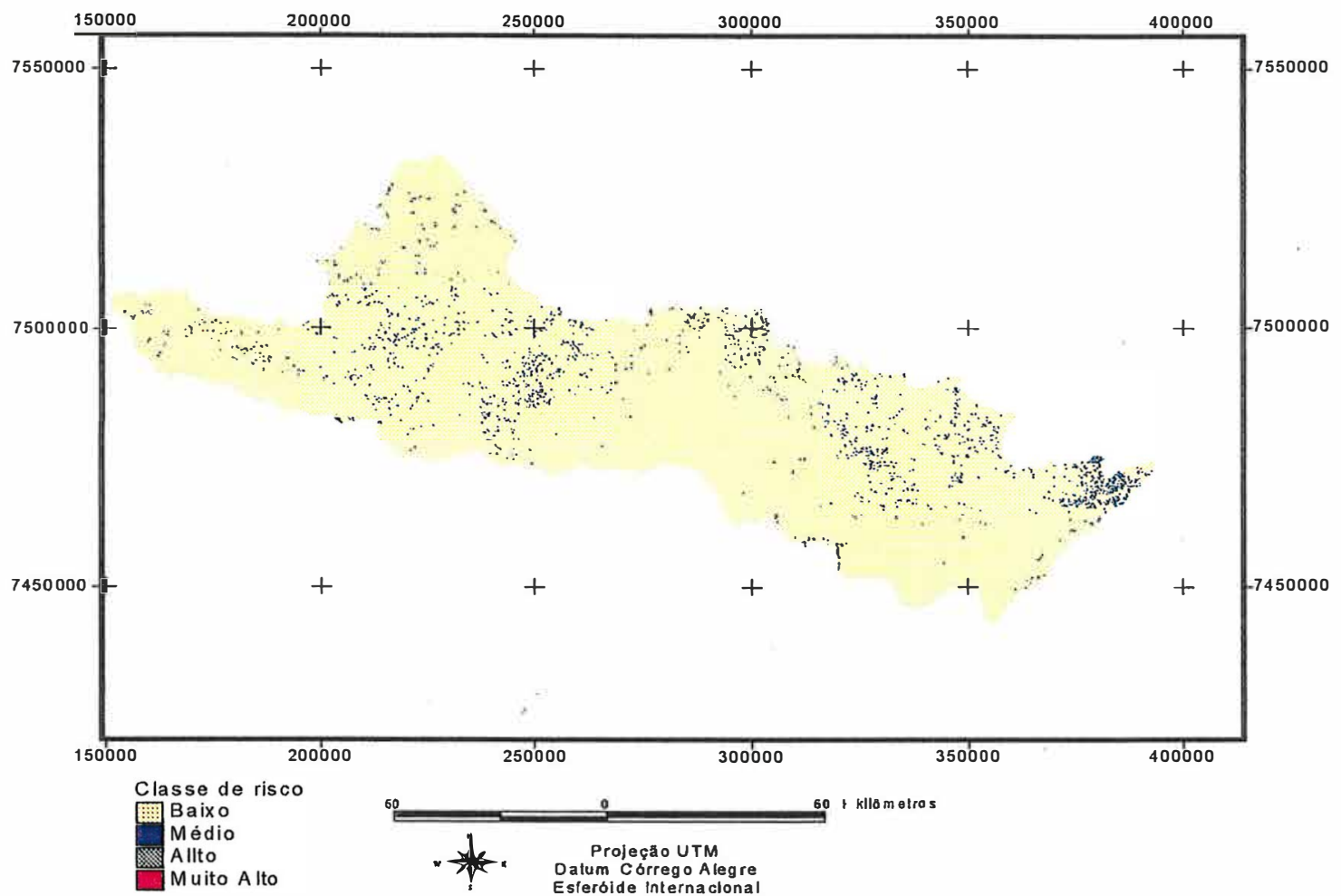

Figura 17. Mapa de risco de erosão da bacia do rio Piracicaba em janeiro de 1978, com prática de plantio em contorno.

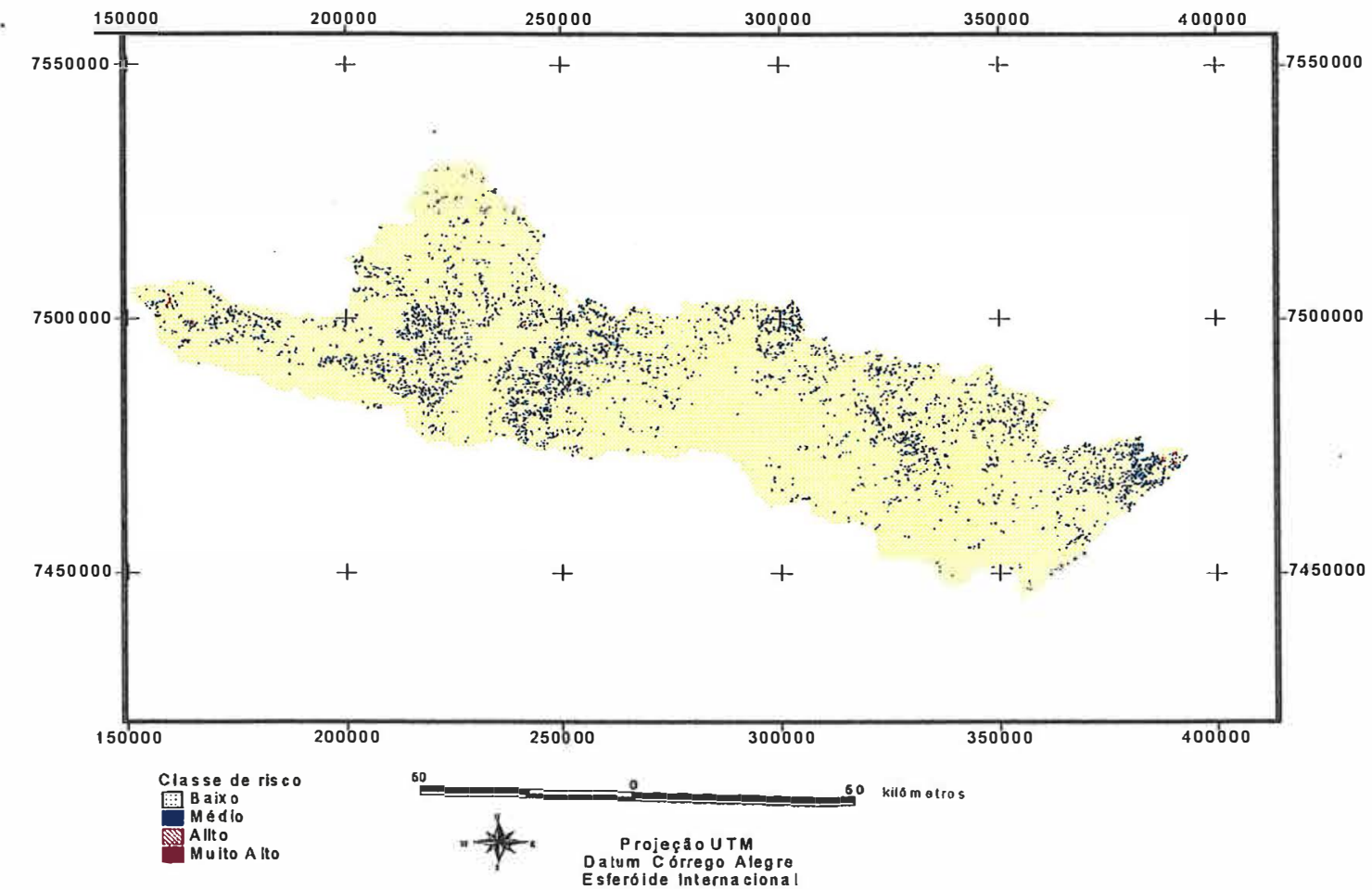

Figura 18. Mapa de risco de erosão da bacia do rio Piracicaba em janeiro de 1978, com prática de plantio morro abaixo. 


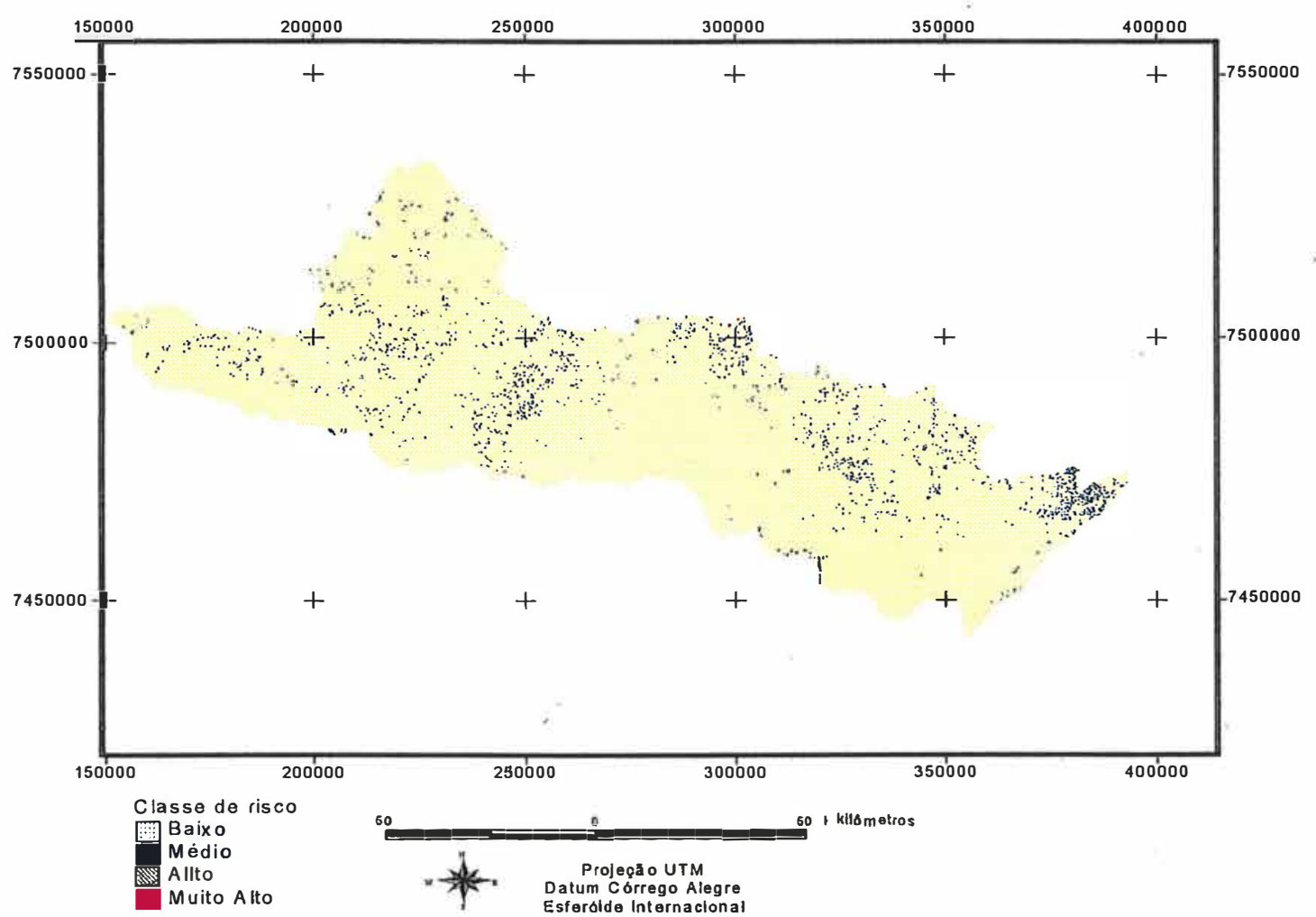

Figura 19. Mapa de risco de erosão da bacia do rio Piracicaba em julho de 1978, com prática de plantio em contorno.

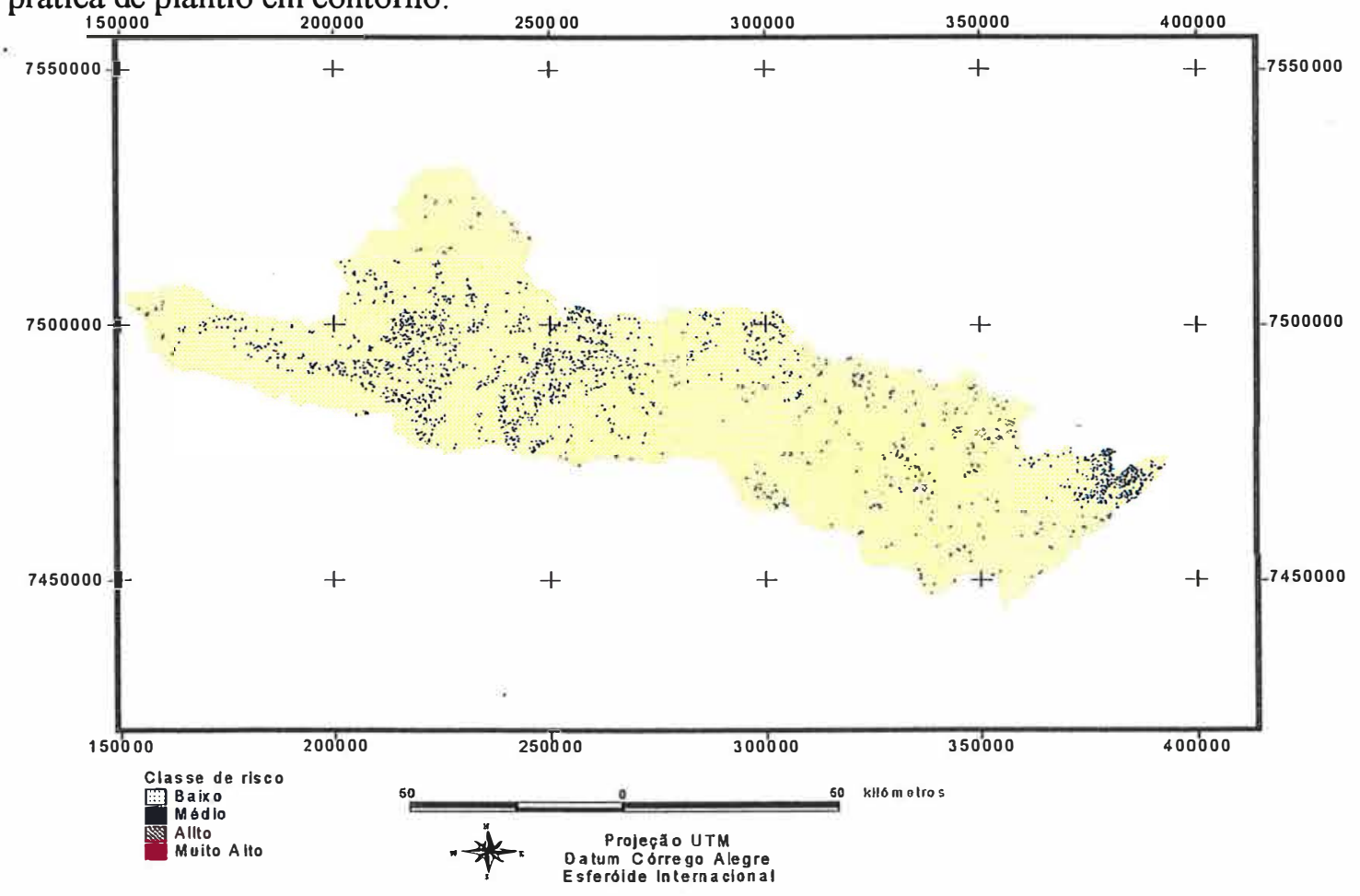

Figura 20. Mapa de risco de erosão da bacia do rio Piracicaba em julho de 1978, com prática de plantio morro abaixo. 


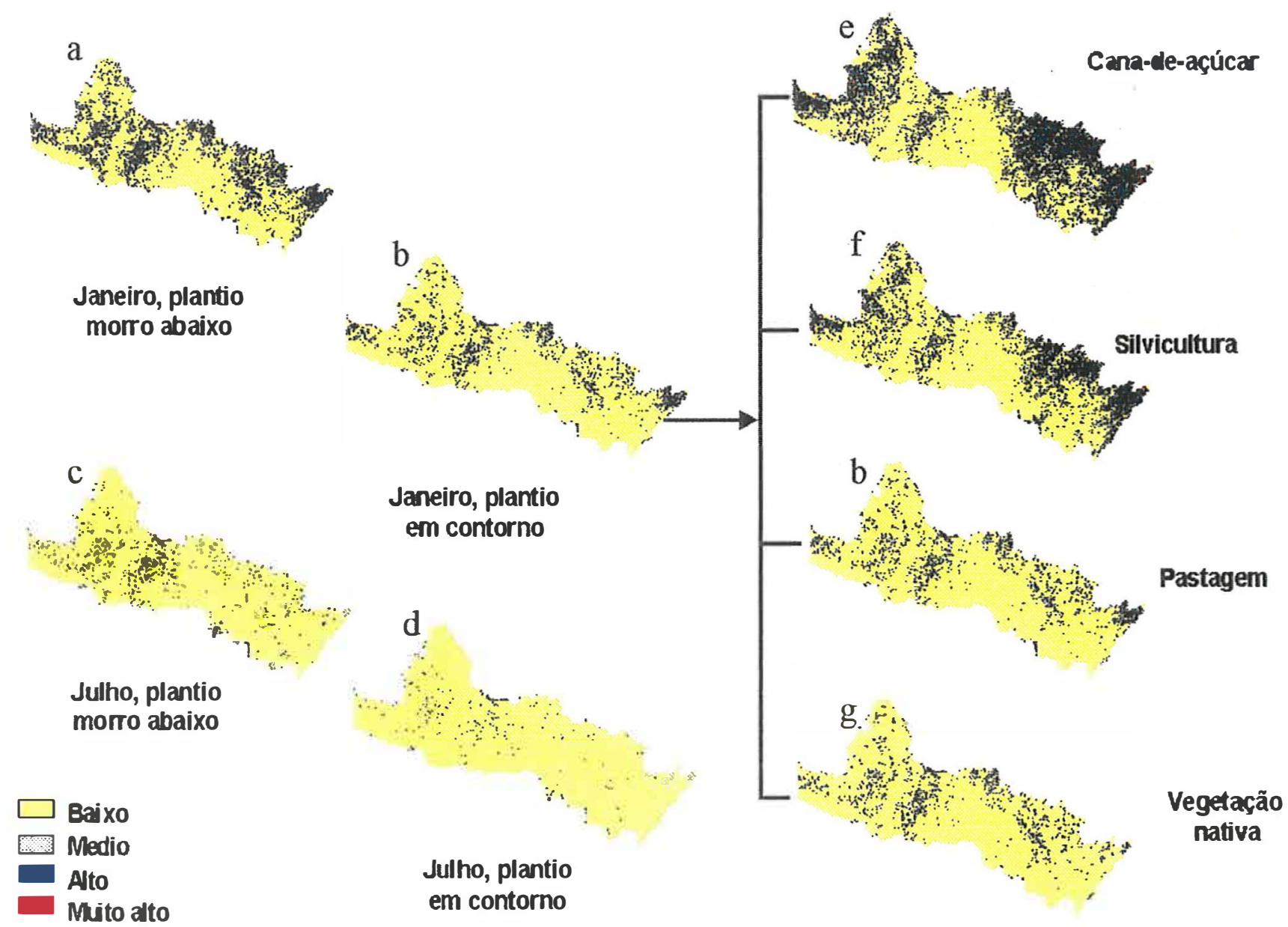

Figura 21 - Mapas de risco de erosão da bacia do rio Piracicaba, para o ano de 1978: a) janeiro com plantio morro abaixo; b) janeiro com plantio em contorno; c) julho com plantio morro abaixo; d) julho com plantio em contorno; e) simulação com substituição da pastagem por cana-de-açúcar; f) simulação com substituição da pastagem por silvicultura e g) simulação com substituição da pastagem por vegetação nativa. 

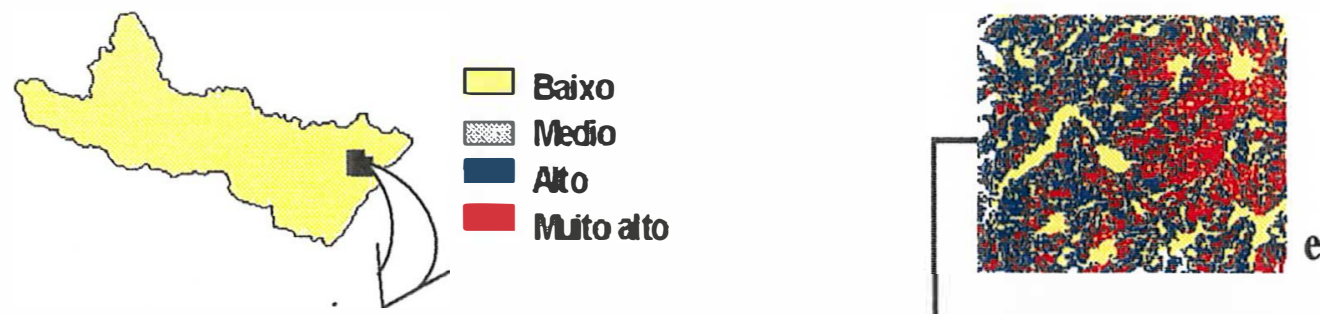

Cana-de-açúcar

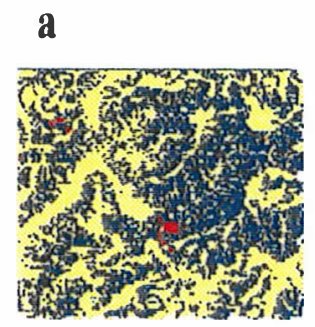

b

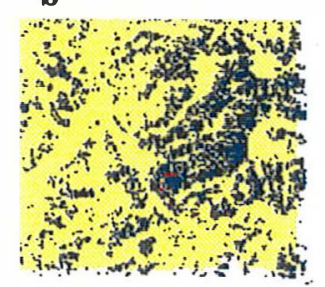

Janeiro, plantio

Janeiro, plantio

morro abaixo
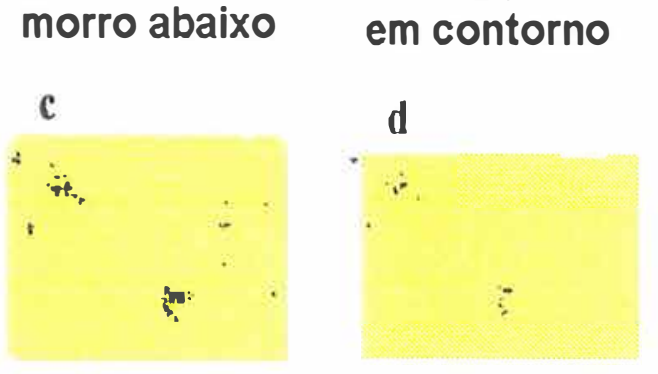

Julho, plantio Julho, plantio morro abaixo em contorno
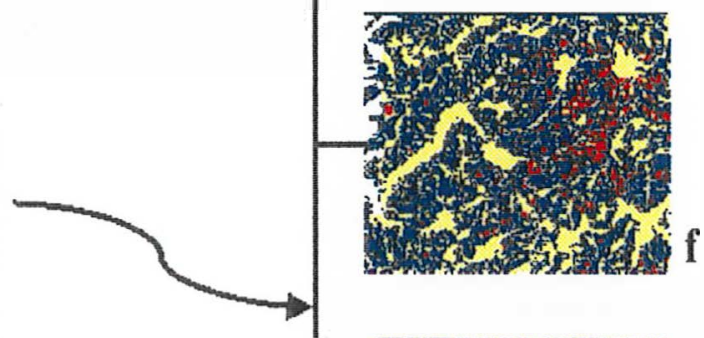

Silvicultura
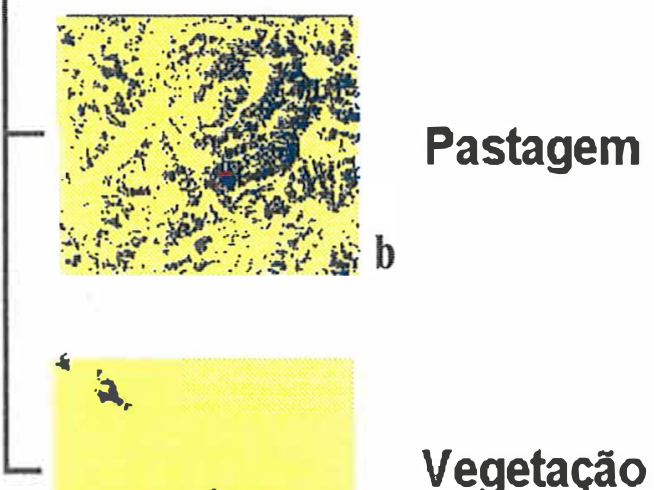

Vegetação

g

nativa

Figura 22 - Detalhes dos mapas de risco de erosão da bacia do rio Piracicaba, para o ano de 1978, apresentados na Figura 21: a) janeiro com plantio morro abaixo; b) janeiro com plantio em contorno; c) julho com plantio morro abaixo; d) julho com plantio em contorno; e) simulação com substituição da pastagem por cana-de-açúcar; f) simulação com substituição da pastagem por silvicultura e g) simulação com substituição da pastagem por vegetação nativa. 
Os riscos de erosão mais acentuados estão localizados principalmente, em duas áreas: ao redor do eixo de maior desenvolvimento urbano (entre as cidades de Piracicaba e Campinas) e próxima às nascentes dos rios que compõem a bacia (Figura 23). Na primeira região mencionada, o maior risco se deve, provavelmente, a inadequação da cultura implantada ao tipo de solo existente. Exemplo disso é a exposição de solos de textura arenosa às chuvas, especialmente sob o cultivo da cana-de-açúcar, que, em seu estágio inicial de desenvolvimento, não oferece uma boa cobertura vegetal. As causas do risco de erosão elevado, na área próxima às nascentes, estão relacionadas à interação dos agentes: relevo acidentado, solos pouco profundos, pastagem mal manejada (algumas vezes bastante degradadas) e pluviosidade concentrada (Figura 23).

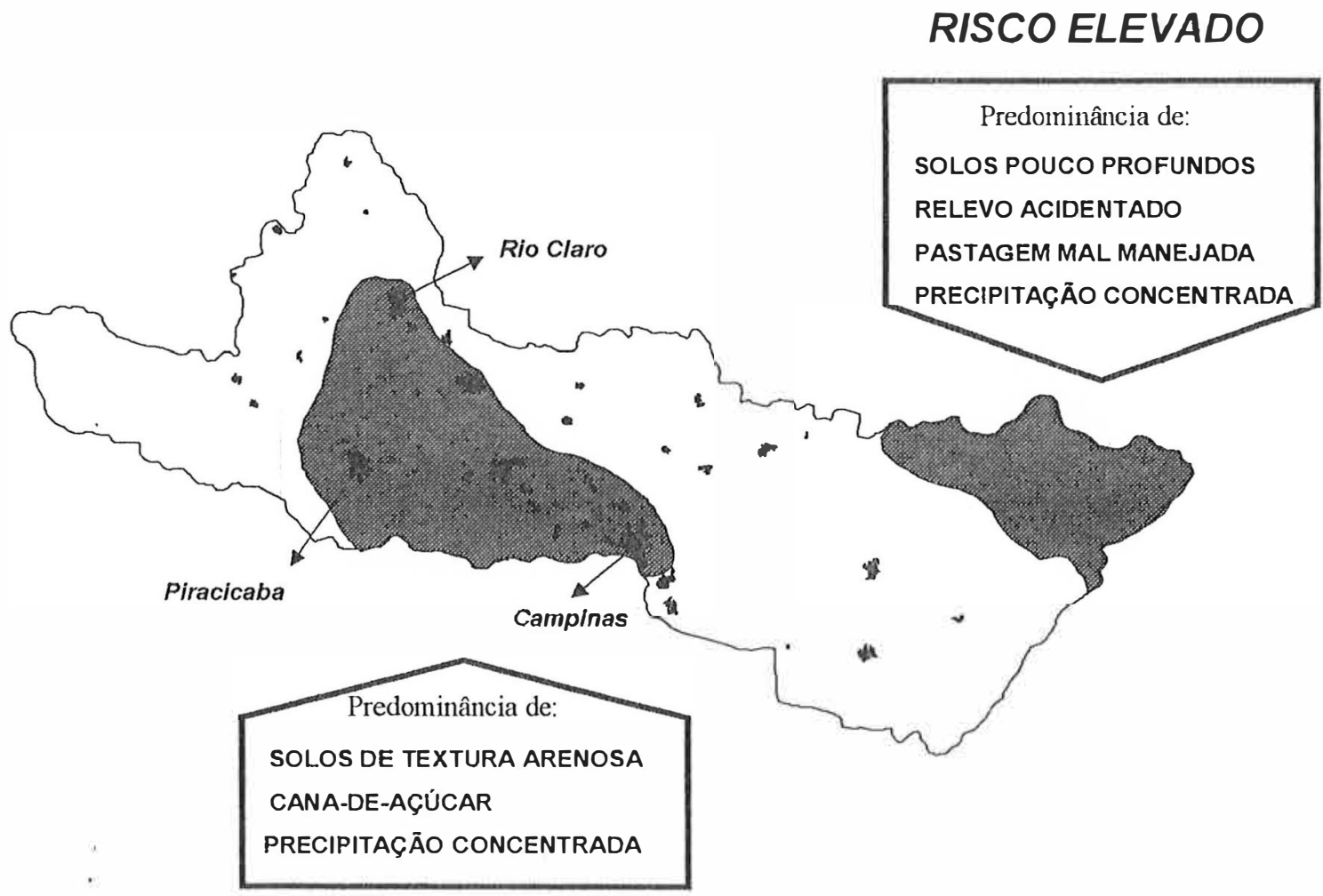

RISCO ELEVADO

Figura 23 - Mapa esquemático das áreas com risco de erosão elevado na bacia do rio Piracicaba, para o ano de 1978. 


\subsubsection{Mapas de risco de erosão para o ano de 1993}

Os mapas de risco de erosão dos solos da bacia do rio Piracicaba foram obtidos para duas épocas distintas do ciclo hidrológico: máxima pluviosidade (mês de janeiro) e mínima pluviosidade (mês de julho) para o ano de 1993. Em cada uma dessas épocas efetuaram-se os cálculos para duas práticas conservacionistas contrastantes: plantio morro abaixo e plantio em contorno (Figuras 24, 25, 26 e 27).

No período de maior pluviosidade, mês de janeiro (Figuras 24 e 25), a maior parte da área da bacia está enquadrada no risco de erosão baixo, para as duas práticas conservacionistas. Essas figuras mostram ainda que o risco de erosão com plantio morro abaixo (Figura 25) é sensivelmente maior quando comparado com o plantio em contorno (Figura 24).

A constatação desta afirmativa pode ser observada na Tabela 6, na qual o risco de erosão baixo para o plantio morro abaixo é de $82,27 \%$, enquanto que para o plantio em contorno o valor é superior $(89,27 \%)$.

A análise das figuras de riscos de erosão para o mês de julho com prática de plantio morro abaixo (Figura 27) e plantio em contorno (Figura 26) evidencia as mesmas tendências dos riscos de erosão observados para o período de chuva, ou seja, os valores de risco baixo de erosão para práticas de plantio em contorno $(99,93$ \%) são superiores aos valores obtidos para a prática de plantio morro abaixo (99,58\%).

Para o mês de julho, independentemente da prática conservacionista adotada, a categoria de risco baixo de erosão predomina em quase a totalidade da área da bacia (Tabela 6), evidenciando a baixa intensidade da chuva e conseqüentemente baixa capacidade de desencadear o processo erosivo. 


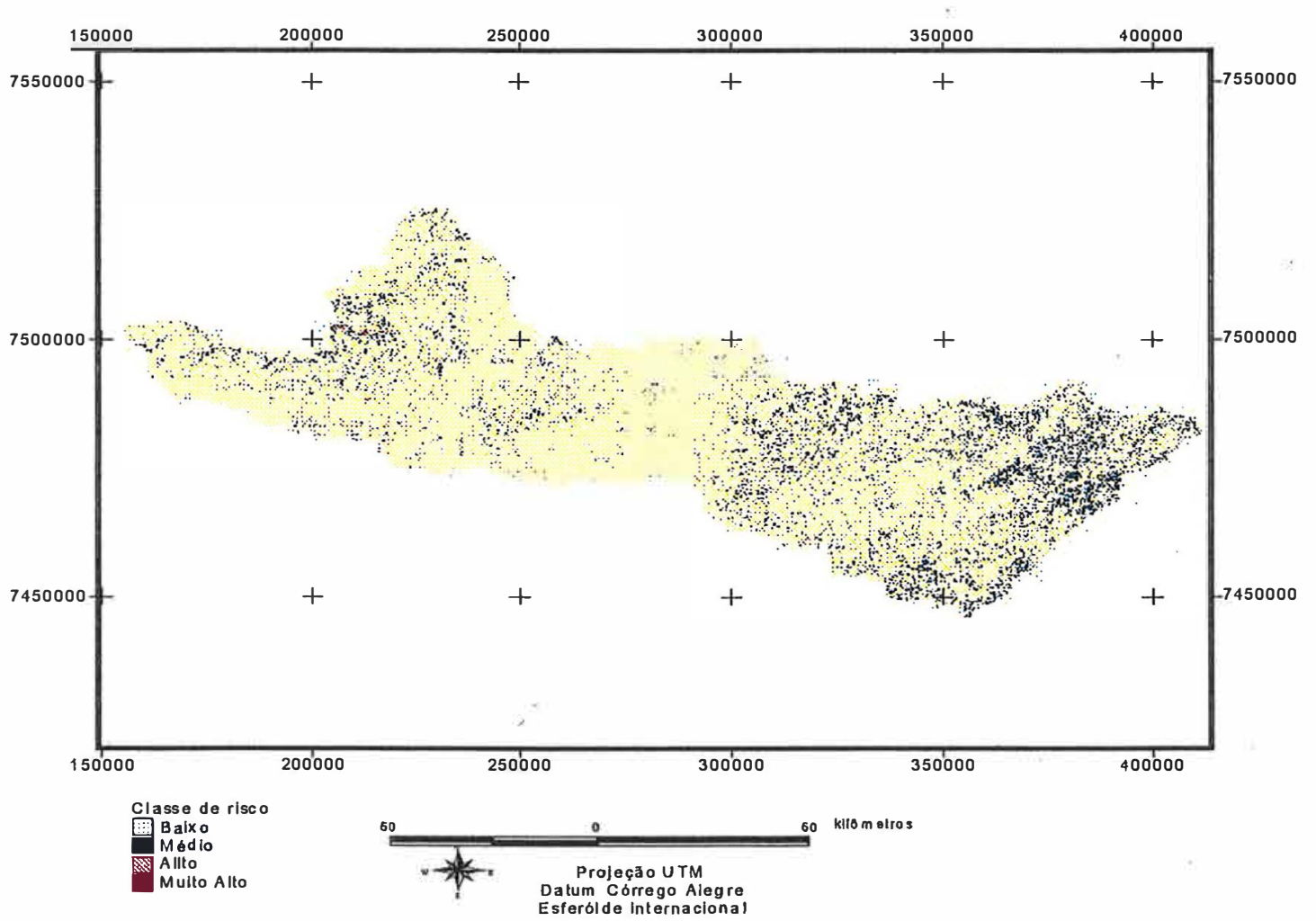

Figura 24. Mapa de risco de erosão da bacia do rio Piracicaba em janeiro de 1993, com prática de plantio em contorno.

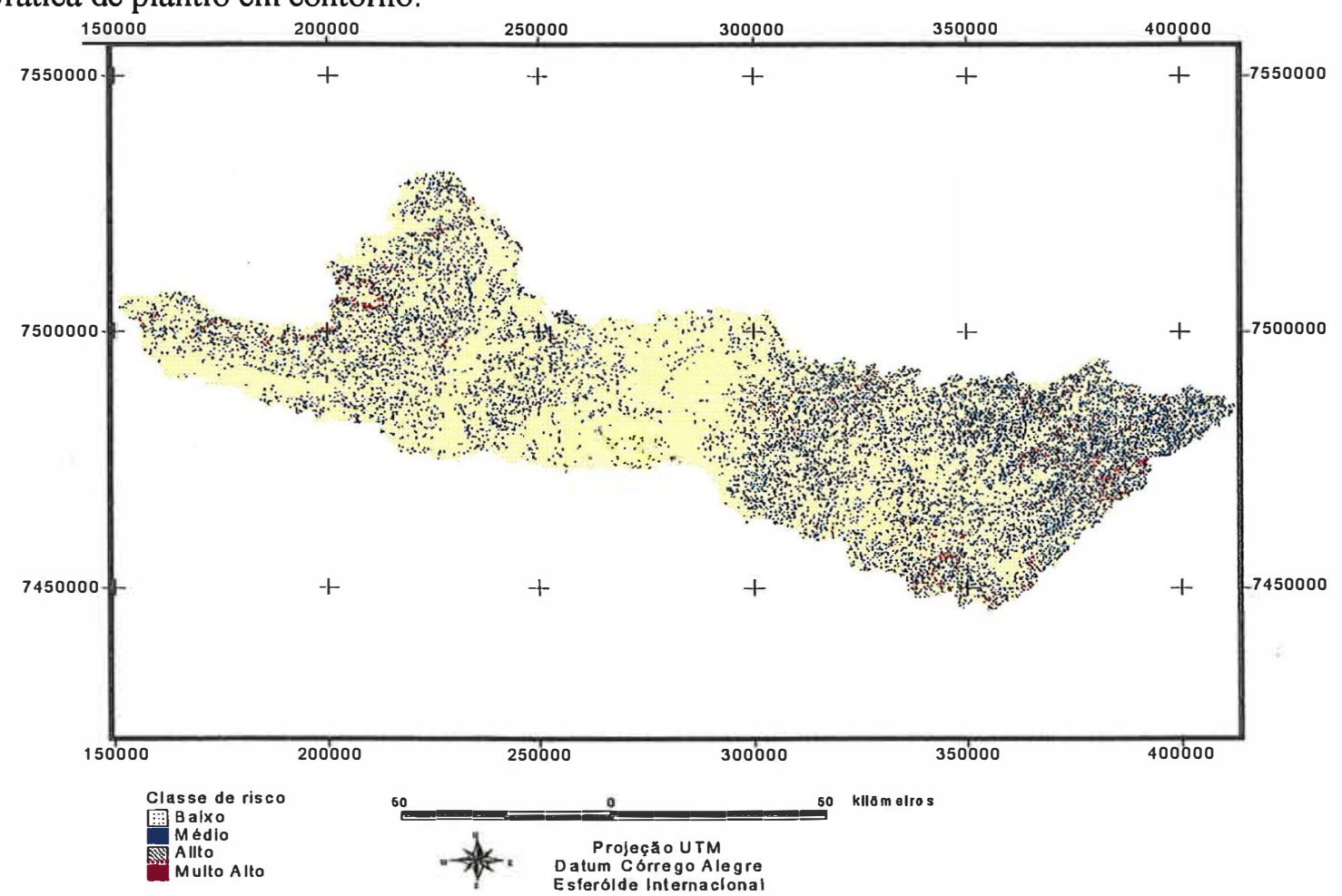

Figura 25. Mapa de risco de erosão da bacia do rio Piracicaba em janeiro de 1993, com prática de plantio morro abaixo. 


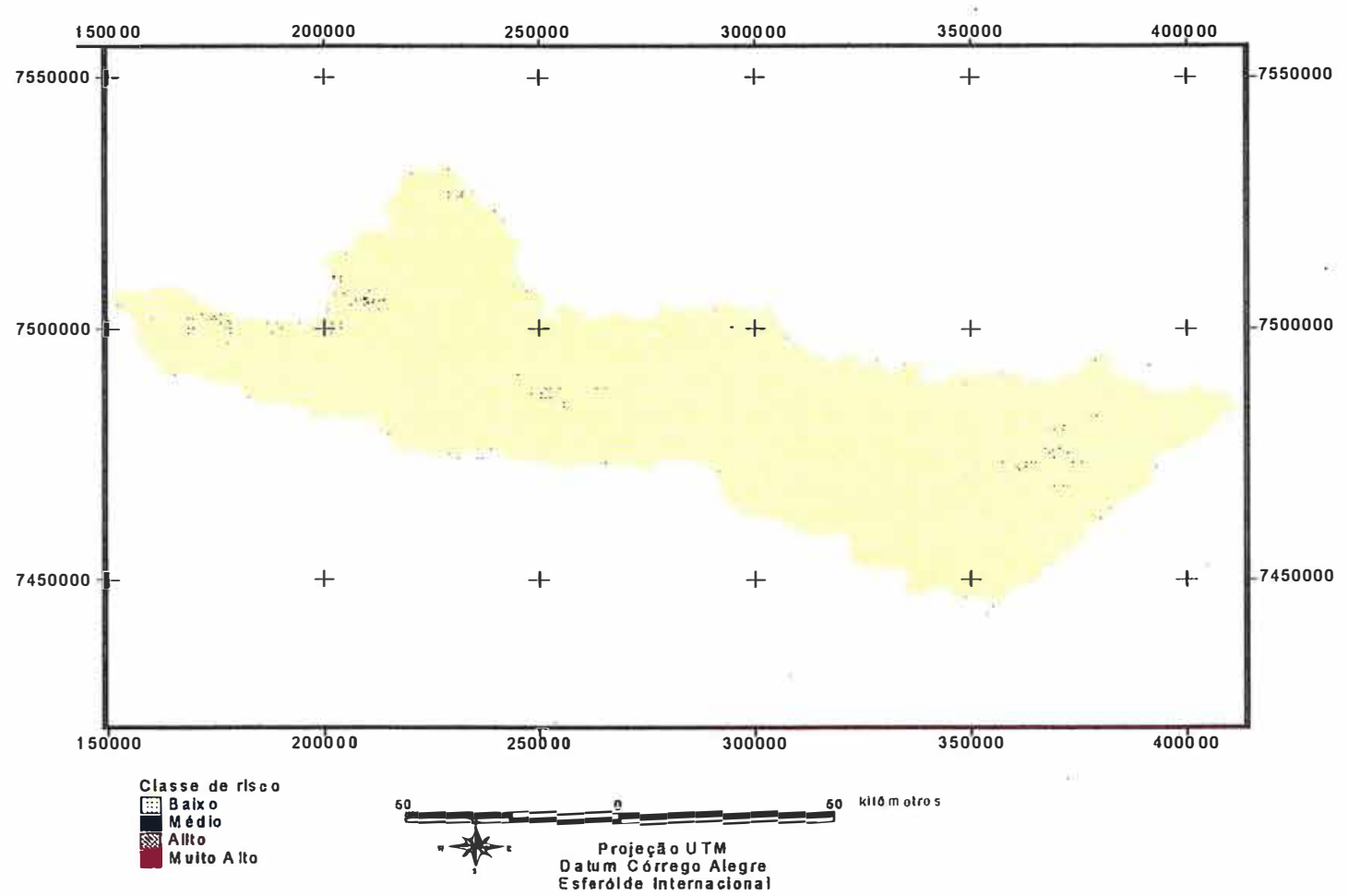

Figura 26. Mapa de risco de erosão da bacia do rio Piracicaba em julho de 1993, com prática de plantio em contorno.

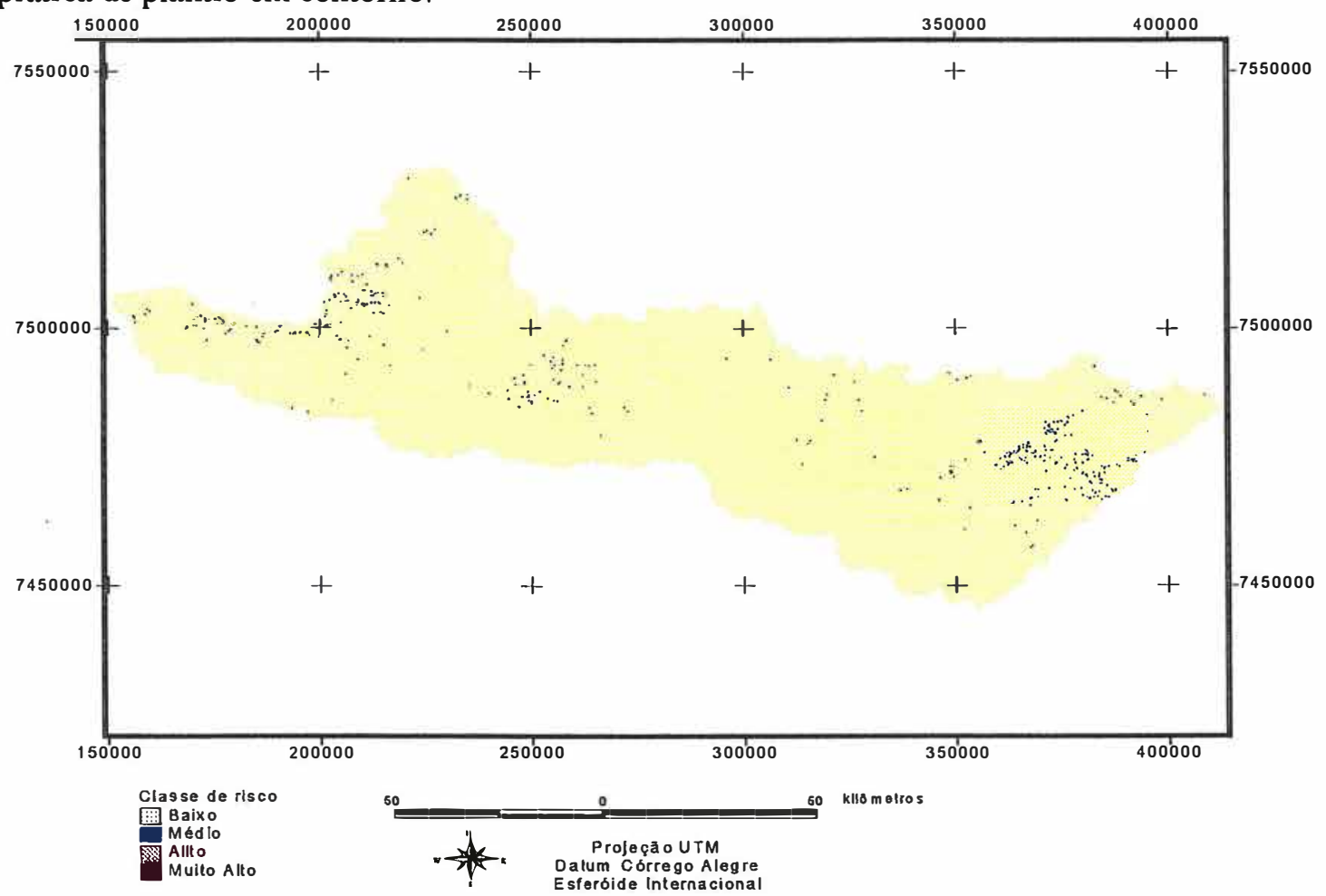

Figura 27. Mapa de risco de erosão da bacia do rio Piracicaba em julho de 1993, com prática de plantio morro abaixo. 
Tabela 6. Distribuição percentual das áreas de risco de erosão na bacia do rio Piracicaba, para os meses de janeiro e julho de 1993 com práticas de plantio morro abaixo e em contorno.

\begin{tabular}{lccccc}
\hline \multirow{2}{*}{ Risco } & Janeiro & Julho & & Janeiro & Julho \\
\cline { 2 - 3 } \cline { 5 - 6 } & \multicolumn{2}{c}{ Plantio morro abaixo } & & \multicolumn{2}{c}{ Plantio em contorno } \\
\hline Baixo & 82,27 & 99,58 & & 89,27 & 99,93 \\
Médio & 7,00 & 0,35 & & 5,71 & 0,07 \\
Alto & 9,66 & 0,07 & & 4,82 & 0,01 \\
Muito Alto & 1,06 & 0,00 & & 0,20 & 0,00 \\
\hline
\end{tabular}

Seguindo a mesma tendência do ano de 1978, os riscos de erosão mais acentuados em 1993, estão localizados principalmente, em duas regiões: ao redor do eixo de maior desenvolvimento urbano (entre as cidades de Piracicaba e Campinas) e próxima às nascentes dos rios que compõem a bacia. Na primeira região mencionada, o maior risco se deve, provavelmente, ao uso inadequado de solos de textura arenosa, especialmente sob o cultivo da cana-de-açúcar, que em seu estágio inicial de desenvolvimento, não oferece uma boa cobertura vegetal. As causas do risco de erosão elevado, na área próxima às nascentes, estão relacionadas à interação dos agentes: relevo acidentado, solos pouco profundos, pastagem mal manejada (algumas vezes bastante degradadas) e pluviosidade concentrada (Figura 28). 
RISCO ELEVADO

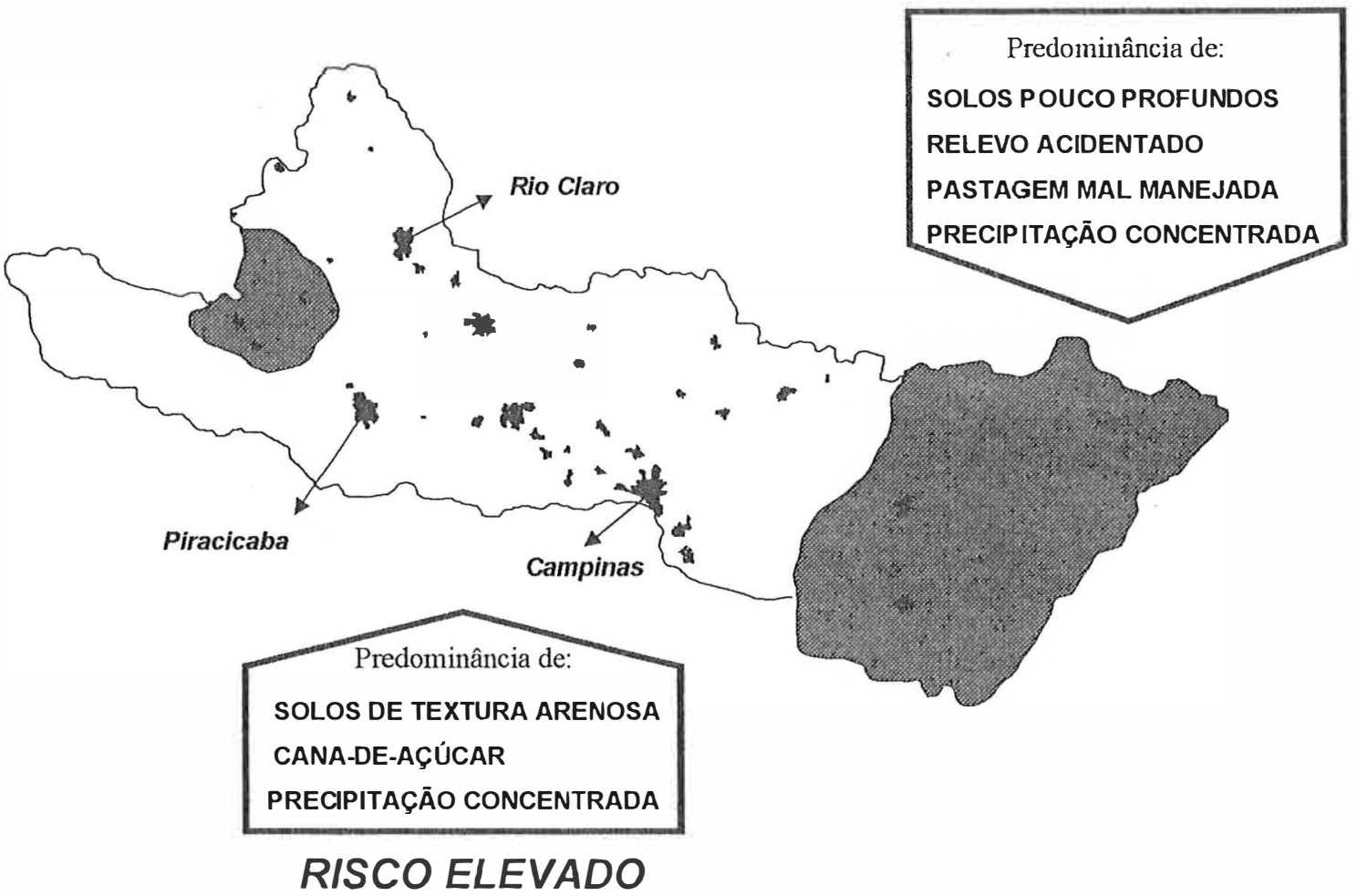

Figura 28 - Mapa esquemático das áreas com risco de erosão elevado na bacia do rio Piracicaba, para o ano de 1993.

\subsubsection{Comparação entre os mapas de risco de erosão dos solos da bacia do rio} Piracicaba para os meses de janeiro e julho de 1978 e 1993

Pode-se constatar que as áreas com risco de erosão baixo na época da seca (julho) para o ano de 1978 apresentaram valores bem maióres (98,6 \%) do que as áreas de risco na época da chuva $(94,8$ \%) para o mesmo ano. Para o ano de 1993, obteve-se a mesma tendência, sendo que as áreas com risco de erosão baixo no mês de julho foram maiores $(99,6 \%)$ do que as apresentadas no mês de janeiro $(82,3 \%)$. Isso demonstra que a precipitação influencia de maneira significativa o risco de erosão (Figura 29), concordando com as afirmações de Bertoni \& Lombardi Neto (1990). 
Analisando-se a Figura 30, pode-se constatar que a erosão é influenciada de maneira direta por fatores antrópicos, como a prática conservacionista. Essa afirmação pode ser comprovada através das seguintes comparações: para a prática de plantio morro abaixo os valores das áreas com risco de erosão baixo foram, independentemente da época, menores do que as de plantio em contorno. Para o ano de 1978 a diferença entre as duas práticas conservacionistas foi de cerca de 3 \%. Já para o ano de 1993, essa diferença foi ainda maior, com valores aproximados de $7 \%$.

A Figura 31 mostra a distribuição percentual das áreas de risco baixo de erosão, comparando duas condições extremas: a pior situação possível para o ano de 1993 e a melhor situação possível para o ano de 1978.

Pode-se observar que a diferença entre as duas condições é significativa (cerca de 17 \%). A classe de risco de erosão baixo para o mês de janeiro de 1993 com adoção da prática de plantio morro abaixo apresentou valores próximos de $82,3 \%$ e o mês de julho de 1978 com plantio em contorno apresentou valores de 99,5\%.

A diferença ocorrida entre as condições contrastantes estão relacionadas, em grande parte, à combinação dos seguintes fatores: cultural/uso e cobertura do solo (aumento da probabilidade de ocorrer erosão acelerada no ano de 1993, em função da mudança no uso da terra entre os anos de 78 e 93, principalmente pela expansão no cultivo da cana-de-açúcar, que possui valor igual a 0,11 e diminuição nas áreas ocupadas por pastagem, que possuem valores iguais a 0,01), erosividade da chuva (janeiro: maior risco de erosão em função dos valores mais elevados do índices de erosão) e práticas conservacionistas (prática de plantio morro abaixo, que possui valor na EUPS igual a 1,0 , é duas vezes mais impactante sob o ponto de vista do processo erosivo quando comparado com o valor 0,5 referente à prática de plantio em contorno - que é mais adequada na conservação do solo e da água). 


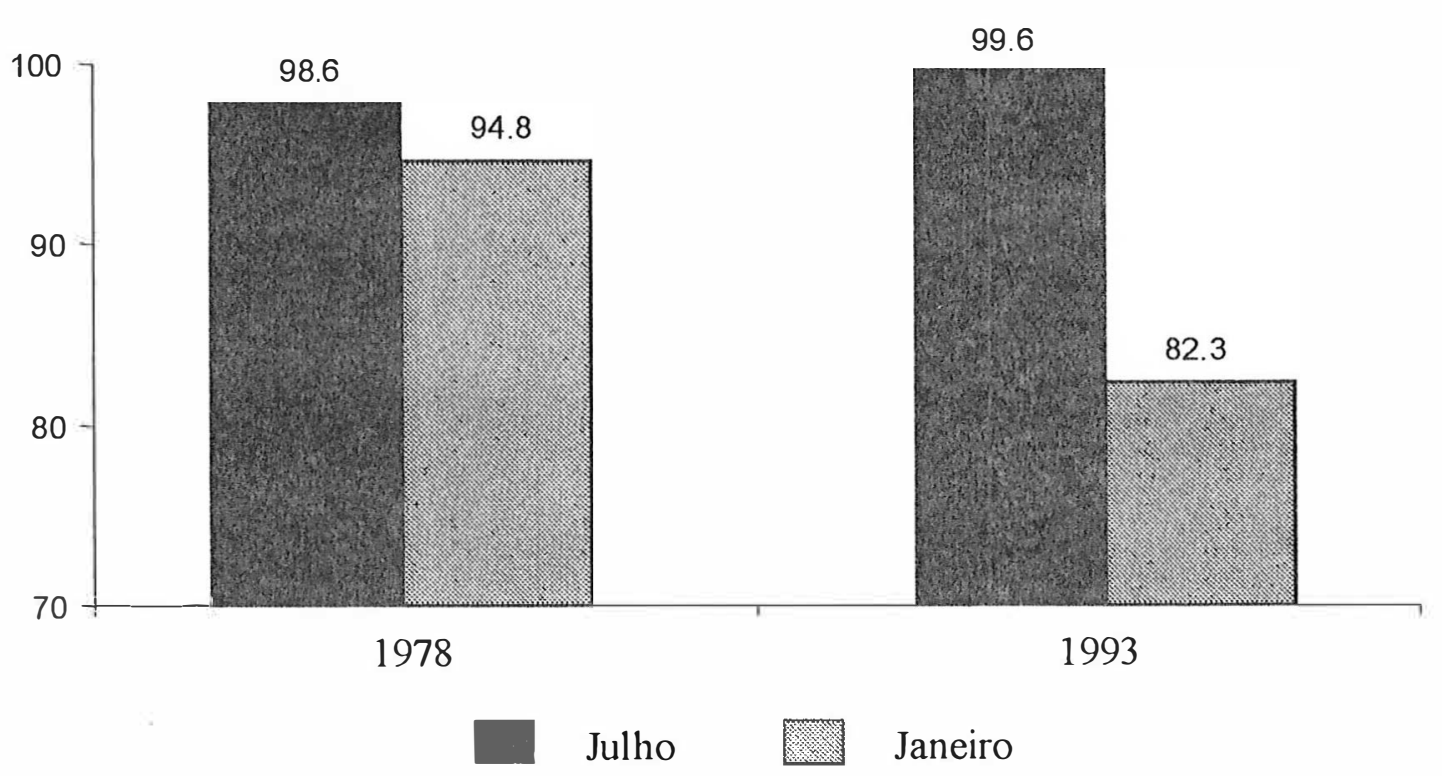

Figura 29. Distribuição percentual das áreas de risco baixo de erosão, com prática morro abaixo, para os anos de 1978 e 1993: efeito da chuva.

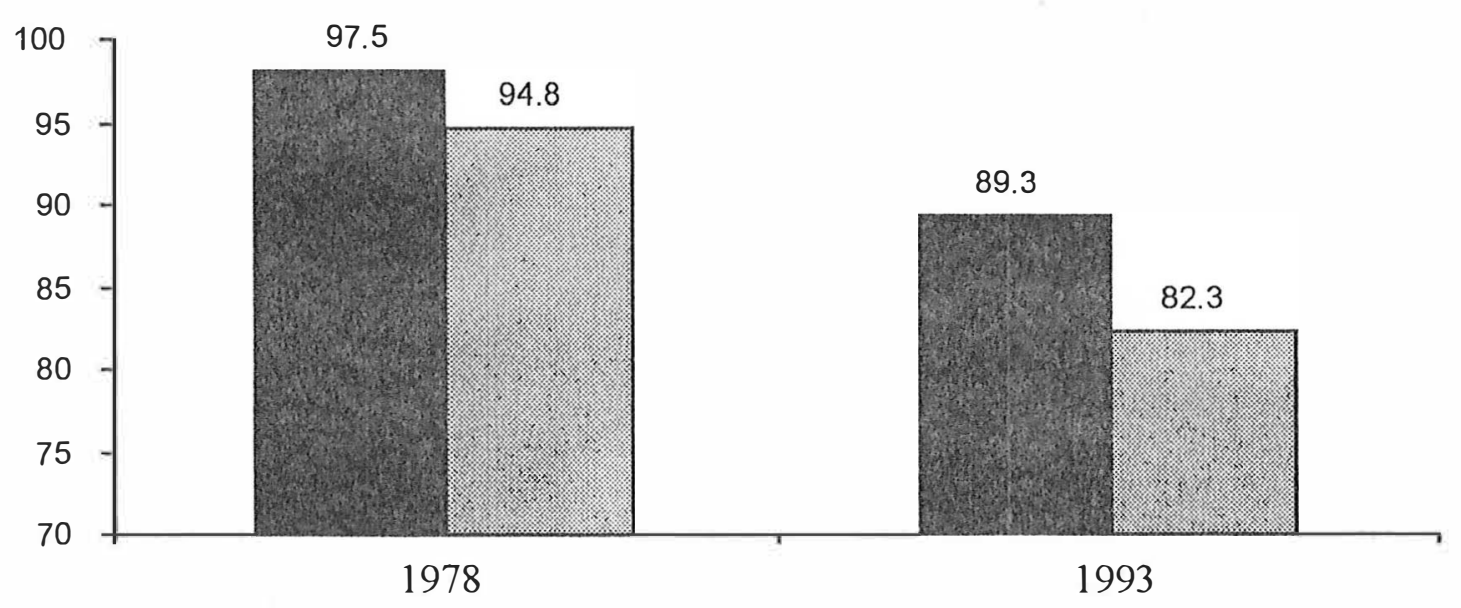

Plantio em contorno Plantio morro abaixo

Figura 30. Distribuição percentual das áreas de risco baixo de erosão, para o mês de janeiro dos anos de 1978 e 1993: efeito das práticas conservacionistas. 
Janeiro de 1993 Plantio morro abaixo

Julho de 1978 Plantio em contorno

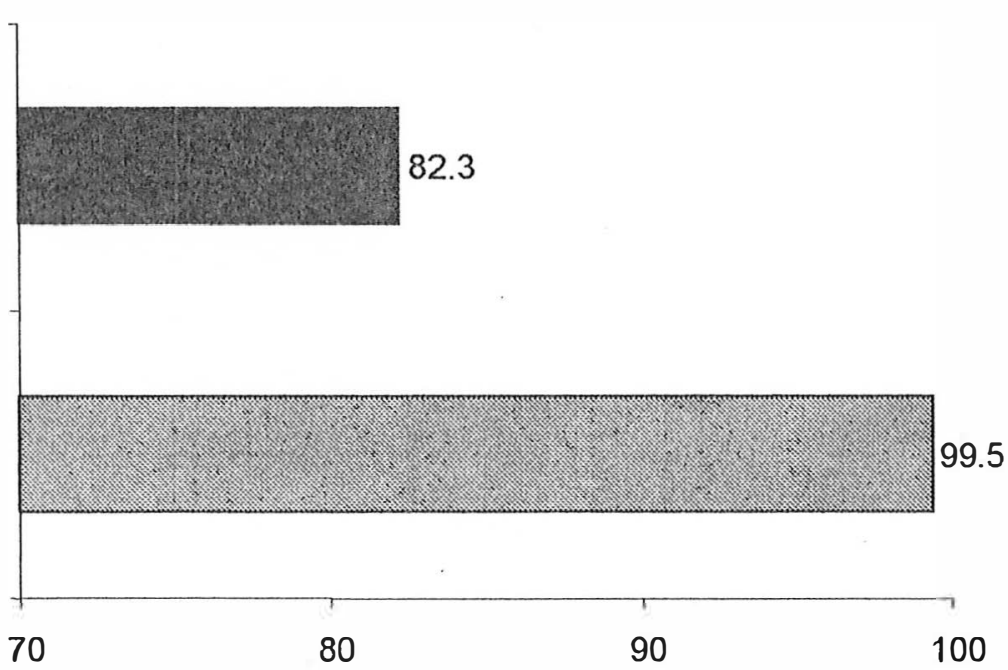

Figura 31. Distribuição percentual das áreas de risco baixo de erosão: pior situação de 1993 x melhor situação de 1978.

\subsection{Verificação no campo do mapa de risco de erosão para o mês de janeiro de 1993 com prática de plantio em contorno}

\subsubsection{Caracterização geral da bacia para fins de estimativa do risco de erosão}

Com a realização das viagens de campo, pode-se verificar que a bacia é ocupada por grandes conjuntos de rochas que, juntamente com outros fatores, delimitam regiões com paisagens próprias.

A região leste da bacia, possui altitude mais elevada, declives mais acentuados, litossolos e solos jovens situados sobre as rochas granito-gnaisse e são cobertos por vegetação nativa, pastagem e reflorestamentos de Pinus e Eucalipto.

A planície de escavação central, denominada Depressão Periférica, é coberta por latossolos, podzólicos e manchas de litossolos sobre rochas sedimentares que formam desde solos arenosos até os mais argilosos.

As colinas onduladas da parte ocidental da bacia são caracterizadas por rochas basálticas e a região é dominada de Cuesta Basáltica. 
As encostas das colinas lateríticas são convexas e aumentam progressivamente até $10 \%$ de declividade à meia-encosta e 20 a $30 \%$ na base da encosta. Nas terras altas as encostas podem ultrapassar os $40 \%$ de declividade. No sopé das colinas verificou-se que ocorrem afloramentos do lençol freático ("minas d'água") que alimentam as zonas de várzea (que são áreas de grande eficiência na captação de sedimentos) ou que provocam a formação de ravinas remontantes.

\subsubsection{Estimativa dos riscos de erosão a partir dos sedimentos dos rios}

Em uma pesquisa dedicada ao estudo de uma bacia hidrográfica, na qual a densidade de rios é elevada, tem-se a idéia de considerar primeiramente, os sedimentos em movimento nos rios para estimar a erosão nas diferentes partes da bacia. Entretanto, convém ressaltar que o transporte de sólidos de um rio é as vezes, bem diferente das perdas em solo das vertentes. Segundo Roose (1996), a erosão medida em uma parte convexa da vertente pode se depositar parcialmente na parte côncava e formar aluviões. Nas paisagens convexo-côncavas sempre se encontram solos coluviais no sopé das colinas e o transporte de sólidos no rio diminui significativamente. Em compensação, nas paisagens novas (vale profundo em forma de "V"), a energia do próprio fluxo escava de maneira mais rápida o leito do rio do que as encostas das colinas. Neste caso particular, o transporte de sólidos no rio é geralmente, superior às perdas de solo das encostas.

As águas do rio Piracicaba (trecho localizado dentro da área urbana de Piracicaba), observadas após chuvas intensas ocorridas no mês de outubro de 1998, possuiam coloração escura, provavelmente devido à grande quantidade de matéria orgânica. Nas regiões próximas aos municípios de São Pedro e Analândia (predomínio de solos bastante arenosos) as águas apresentavam-se transparentes, enquanto que a maioria dos solos dessa região possuem coloração avermelhada.

Sendo difícil comparar as perdas de solo nas vertentes com a turbidez das águas dos rios, foram consultados dados sobre transporte de sólidos totais no rio Piracicaba e em seus afluentes, obtidos pelo Projeto Piracena (Projeto Piracena, 1998). 
A média mensal do conteúdo de sedimentos varia de 20 a $30 \mathrm{mg} \mathrm{L}^{-1}$ na estação mais seca e de 100 a $200 \mathrm{mg} \mathrm{L}^{-1}$ (máximo de $500 \mathrm{mg} \mathrm{L}^{-1}$ ) no período das águas (Krusche et al., 1997). Estes valores são relativamente baixos, tanto para os períodos de pluviosidade máxima (janeiro/fevereiro) quanto para o período de estiagem (junho/julho) e sugerem que os solos são bastante porosos, coesos e estáveis (Roose ${ }^{1}$ ). A carga de sedimentos média das águas do rio Piracicaba aumenta apenas entre a parte mais alta da bacia e a parte baixa: de 20 a $28 \mathrm{mg} \mathrm{L}^{-1}$ no período de pouca chuva, e de 120 a $150 \mathrm{mg} \mathrm{L}^{-1}$ no período das águas. Ao multiplicar esses conteúdos sólidos pelos volumes escoados nos meses de inverno e verão, obtém-se massas impressionantes de sedimentos. Porém, dividindo-se esses transportes de sedimentos pela superfície das bacias, obtém-se erosões específicas modestas em toneladas por quilômetro quadrado.

Todos esses resultados, mesmo muito parciais, mostram que de uma maneira geral, a erosão não é tão grave na bacia $\left(\operatorname{Roose}^{1}\right)$. Todavia, pode ocorrer de maneira localizada e temporariamente, conteúdos bem mais elevados (carga sólida máxima = $500 \mathrm{mg} \mathrm{L}^{-1}$ ) correspondentes à ravinamentos ou acidentes bem localizados de desbarrancamentos de margens mal protegidas, como já relatado por Oliveira (1994), que observou movimento de massa nas margens do rio Paranapanema (SP/PR).

De forma simplificada, pode-se afirmar que os valores pouco significativos de cargas sólidas em suspensão nas águas do rio Piracicaba não são uma prova absoluta de riscos baixos de erosão nas vertentes. Roose (1996) demonstrou que, em solos de coloração escura na região Brabant belga, o desprendimento de partículas e agregados pelo choque das gotas de chuva ultrapassa $130 \mathrm{t} \mathrm{ha}^{-1} \mathrm{ano}^{-1}$ (medidas em funis colocados na superfície do terreno), as perdas de solo por erosão de uma parcela $\left(100 \mathrm{~m}^{2}\right)$ atingiram valores de $30 \mathrm{t} \mathrm{ha}^{-1}$ mesmo quando o transporte de sólidos pelo rio não ultrapassaram as $130 \mathrm{t} \mathrm{ha}^{-1} \mathrm{ano}^{-1}$, pois os sedimentos são capturados por uma faixa de plantas herbáceas que protegem as margens do rio. Assim, as perdas pouco significativas constituem um indicador do baixo nível de erosão, em particular em períodos de pouca pluviosidade.

\footnotetext{
${ }^{1}$ Roose, E. (ORSTOM. Montpellicr, França). Comunicação pessoal, 1998.
} 
Da mesma maneira, na bacia do Piracicaba, foi possível encontrar uma série de captadores de sedimentos, tais como: as linhas de resíduos (palhada) deixadas na superfície do solo e espaçadas a cada 5 linhas cultivadas com cana-de-açúcar; as regiões côncavas de certas vertentes em áreas de pastagens; as vegetações florestais que recobrem as ravinas e fundos de vales abruptos; as áreas de várzea (alagadas); lagoas, barragens e grandes represas.

\subsubsection{Risco de erosão observado em diferentes usos da terra}

\subsubsection{Cana-de-açúcar}

Nas áreas de cana-de-açúcar, que ocupam cerca de $35 \%$ da área da bacia, foram analisados cultivos com idade variando de um a seis meses de rebrota, em diferentes tipos de solos. A seguir é apresentado um resumo das observações de campo para os riscos de erosão em função da declividade e do tipo de solo para essa cultura:

Nas paisagens convexas, sobre Latossolos argilosos, se a declividade for:

$$
\begin{aligned}
& <10 \% \text { o risco de erosão é R1 } \\
& >10 \% \text { o risco de erosão é R2 } \\
& >20 \% \text { o risco de erosão é R3 }
\end{aligned}
$$

Nas paisagens de superfícies côncavas sobre Litossolos, se a declividade for:

$$
\begin{aligned}
& <10 \% \text { o risco de erosão é R1 a R2 } \\
& >10 \% \text { o risco de erosão é R2 a R3 } \\
& >20 \% \text { o risco de erosão é R3 a R4 }
\end{aligned}
$$

Nas colinas sobre solos Podzólicos, se a declividade for:

$<10 \%$ o risco de erosão é R1

$>10 \%$ o risco de erosão é R2

$>20 \%$ o risco de erosão é R3 a R4 


\subsubsection{Vegetação florestal}

Nas situações de matas naturais ou de reflorestamento de Eucaliptos e Pinus, observou-se que nas áreas onde existem um sub-bosque e uma cobertura de folhas e galhos na superfície do solo (serapilheira), o risco de erosão é R1, para qualquer que seja o declive. Entretanto, algumas áreas com reflorestamento recém implantado, não possuíam serapilheira e foi possível observar erosão linear entre as linhas das árvores (quando a declividade é $>15 \%$ ), fazendo com que o risco de erosão para essas áreas se eleve a R2 e R3.

\subsubsection{Citros}

As plantações de citros geralmente são delimitadas por cercas vivas e as entrelinhas são cobertas por diferentes vegetações: ervas daninhas que são roçadas duas ou três vezes por ano, grama batatais ou mesmo são cultivadas principalmente com milho, milheto e soja. De modo geral, os riscos de erosão são reduzidos (R1) para as áreas com citros, devido à cobertura vegetal e à declividade não muito elevada $(<15 \%)$.

\subsubsection{Pastagem}

Para as áreas ocupadas por pastagens (cerca de $23 \%$ da bacia), as observações de terreno não mostraram traços de erosão nos declives inferiores à $10 \%$ (portanto, risco de erosão R1), alguns sulcos foram observados sobre declives de mais de $10 \%$, localizados nos caminhos preferenciais de deslocamento do gado e em zonas super pastejadas (risco de erosão de R2 a R3). Foram observados alguns movimentos de massa, nos taludes de terraços sobre forte declive e alguns ravinamentos profundos sobre os solos Podzólicos arenosos e Areia Quartzosa (principalmente na região de São Pedro).

Pode-se dizer, que os problemas de erosão em pastagens, estão ligados ao super pastejo (degradação da gramínea), mas sobretudo à passagem freqüente dos animais sobre os mesmos caminhos que os levam aos bebedouros. Isso deixa o caminho 
descoberto de vegetação, fazendo com que a água escoe por ele de forma preferencial, formando sulcos e posteriormente (se nenhuma providência for tomada) voçorocas. Aliás, Queiroz Neto \& Christofoletti (1968) e Bigarella \& Mazuchowshi (1985) já relatavam que a concentração do escoamento tende a ocorrer em linhas preferenciais, podendo provocar o sulcamento e dando início ao processo de ravinamento.

\subsubsection{Comparação entre o risco de erosão obtido pelo mapa e o observado no campo}

A Tabela 7 mostra a comparação entre os riscos de erosão dos solos da bacia do rio Piracicaba obtidos do mapa de risco a erosão do mês de janeiro de 1993 com prática de plantio em contorno e os dados obtidos na verificação no campo (verdade terestre).

As letras do alfabeto indicam a localização dos 26 pontos observados no campo (Figura 32). As localizações exatas desses pontos foram obtidas através do uso de um GPS (Global Positioning System).

Pode-se verificar que o número de acertos é bem superior (21 resultados coincidentes) ao de erros (5 resultados diferentes), conferindo um valor aproximado de $80 \%$ de correspondência entre as estimativas dos riscos de erosão obtidas pelo mapeamento e pela observação de campo.

Esses resultados indicam que a metodologia de aplicação da EUPS através da utilização de técnicas de geoprocessamento foi satisfatória, concordando com autores como Pelletier (1985), Ranieri (1996), Saiz e Valério Filho (1996), Brito et al. (1998) e Gomes \& Maldonado (1998).

O cálculo do fator topográfico (LS), utilizando a metodologia proposta por Hickey (1994), não demonstrou na presente pesquisa, os problemas apontados por Hamlet et al. (1992) e por Jäger (1994) que tiveram dificuldades na estimativa do comprimento do declive em bacias hidrográficas. Os resultados da checagem de campo ( $80 \%$ de correspondência), demonstram que o fator topográfico fói estimado de forma satisfatória, assim como aqueles valores obtidos por Desmet \& Govers (1996), que também utilizaram um algoritmo computacional para o cálculo deste fator. 
A utilização de imagens orbitais como base para obter o uso da terra e posterior utilização com o SIG para a obtenção de mapas de risco de erosão, demonstrou ser uma boa alternativa para a geração de informações em grandes áreas, concordando com De Lima et al. (1992), Fraser et al. (1995) e Batjes (1996). Permite ainda, como já mencionado por Castro (1992) e Guangwei (1997), uma utilização mais intensiva de dados de sensores remotos, uma vez que haja um maoir aprimoramento das técnicas de classificação digital.

Aliás, a obtenção de mapas para avaliar os riscos de erosão em grandes áreas constitui uma ferramenta auxiliar imprescindível na racionalização do uso e ocupação da terra como conseqüente reflexo no ambiente, concordando com observações de Ventura et al. (1988), Jäger (1994), Moraes et al. (1996), Sheng et al. (1997) e Mantel \& Van Engelen (1997). 
Tabela 7. Comparação entre os riscos de erosão obtidos do mapa (gerado através do geoprocessamento) e os riscos observados no campo.

\begin{tabular}{|c|c|c|c|}
\hline O bservação & $\mathrm{R}$ isco-mapa & $\mathrm{R}$ isco - c ampo & Comparação \\
\hline a & médio & $\mathrm{R} 2$ & $*$ \\
\hline $\mathrm{b}$ & baixo & R 1 & $*$ \\
\hline c & baixo & R 1 & $*$ \\
\hline $\mathrm{d}$ & baixo & R 1 & $*$ \\
\hline $\mathrm{e}$ & médio & R 3 & $* *$ \\
\hline $\mathrm{f}$ & baixo & R 2 & $* *$ \\
\hline g & baixo & R 1 & $*$ \\
\hline h & baixo & R 1 & $*$ \\
\hline I & médio & R 2 & $*$ \\
\hline $\mathrm{j}$ & médio & $\mathrm{R} 2$ & $*$ \\
\hline $\mathrm{k}$ & baixo & $\mathrm{R} 2$ & $* *$ \\
\hline 1 & baixo & R 3 & $* *$ \\
\hline $\mathrm{m}$ & baixo & R 1 & $*$ \\
\hline $\mathrm{n}$ & médio & $\mathrm{R} 2$ & $*$ \\
\hline o & baixo & R 1 & $*$ \\
\hline $\mathrm{p}$ & baixo & R 3 & $* *$ \\
\hline$q$ & baixo & R 1 & $*$ \\
\hline$r$ & baixo & R 1 & $*$ \\
\hline $\mathrm{s}$ & baixo & R 1 & $*$ \\
\hline $\mathrm{t}$ & baixo & R 1 & $*$ \\
\hline $\mathrm{u}$ & baixo & R 1 & $*$ \\
\hline v & baixo & R 1 & $*$ \\
\hline $\mathrm{x}$ & baixo & R 1 & $*$ \\
\hline $\mathrm{y}$ & médio & R 2 & $*$ \\
\hline$w$ & baixo & R 1 & $*$ \\
\hline $\mathrm{z}$ & baixo & R 1 & $*$ \\
\hline
\end{tabular}

* mesmo resultado

** resultado diferente 


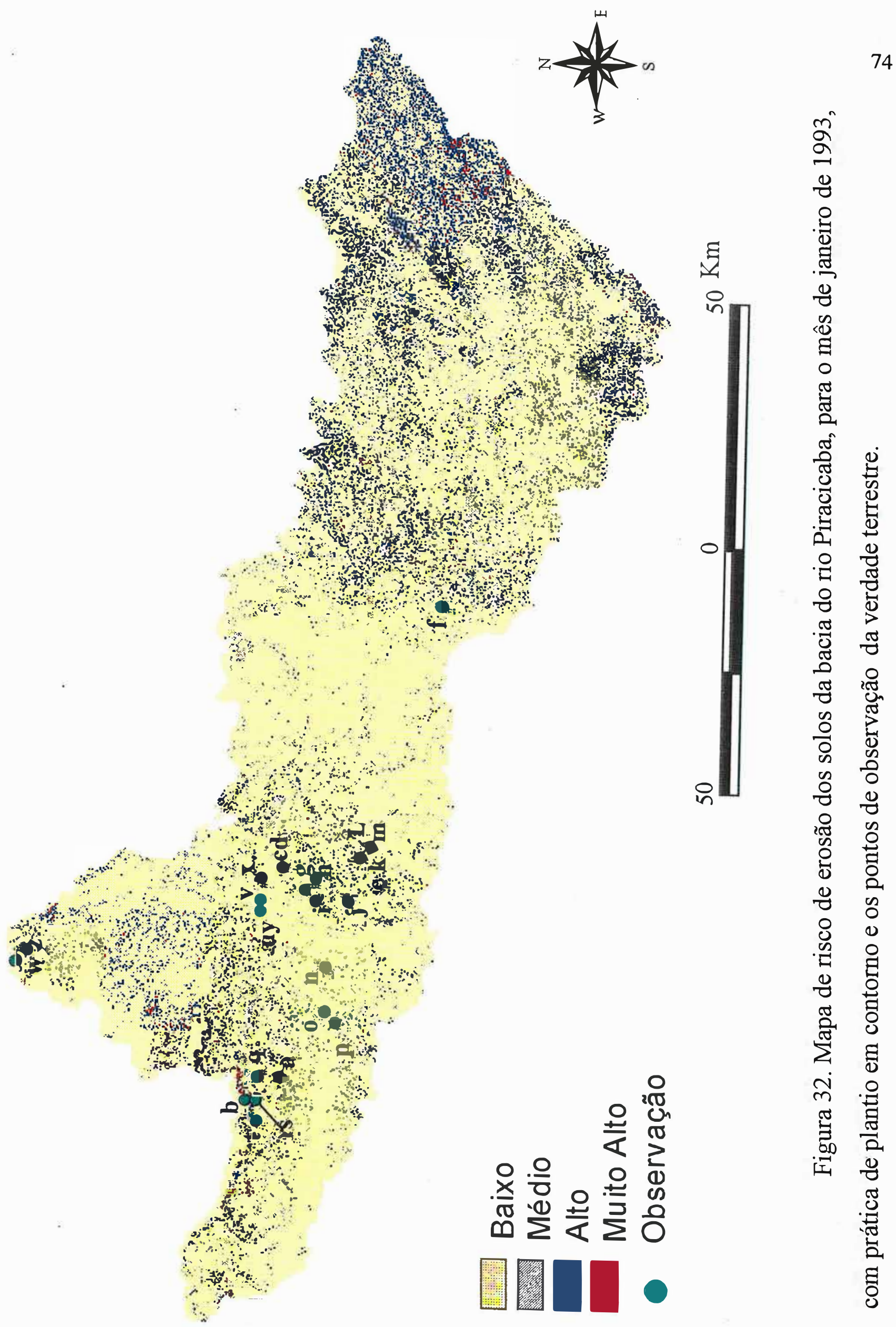




\subsubsection{Limitaçõoes da verificação no campo do mapa de risco de erosão}

As observações foram realizadas próximas aos eixos das rodovias, nas duas zonas principais onde os processos de erosão são mais freqüentemente limitados a R1 R2 (declive $<10 \%$ ) e a R2-R3 nos sopés de colinas de declive mais acentuado, onde as estradas rurais não dispersam suas águas de drenagem sobre os campos cultivados.

Sugere-se, como atividade futura, a realização de um complemento nas observações, para contemplar as áreas medianas e a parte alta (região das nascentes dos rios) da bacia, que em função das dimensões a serem percorridas, não puderam ser analisadas de maneira mais completa.

Após a observação da presença de restos de folhas e sub-bosques nas matas naturais e nas plantações de Eucaliptos e Pinus e mato nas entrelinhas de citros, sugerese que as próximas observações se concentrem nas áreas de cana-de-açúcar, que representam $35 \%$ da superficie da bacia. É importante, também, verificar algumas regiões com declives bem escarpados e presença de vegetação florestal na parte alta da bacia (para observar movimentos de massa) e sobretudo nas pastagens que representam $23 \%$ da bacia e podem apresentar riscos não negligenciáveis, em particular, em encostas fortes (onde podem ocorrer deslizamentos) e próximos a nascentes (ocorrência de ravinamento remontante), conforme já alertado por Lal (1998; 1999), que verificou os impactos da erosão acelerada na produção agrícola de regiões tropicais.

Pode-se questionar se a data das observações (outubro, época de corte da canade-açúcar) é a melhor escolhida em função dos riscos calculados em janeiro, mês mais chuvoso. A estação das chuvas começou com três tempestades agressivas totalizando mais de $120 \mathrm{~mm}$ que causaram localmente inundações durante alguns dias. O corte da cana-de-açúcar começou em julho e se prolongou até dezembro de 1998.

A superfície do solo pode estar parcialmente desnudada embora haja entre 5 e 40 $\%$ de resíduos deixados na superficie do solo após as práticas culturais. Quanto à folhagem, ela cobre aproximadamente $20 \%$ do solo a cada mês, sendo que cinco meses após o corte da cana-de-açúcar, o solo estará protegido do impacto das gotas de chuva. Aliás, a evolução do crescimento das folhas da cana-de-áçucar, observado no campo, 
vem confirmar as observações realizadas por Lombardi Neto (1992), que estimou as perdas de solo por erosão na microbacia do córrego São Joaquim, município de Pirassunuinga (SP). Em contrapartida, a colheita mesmo sendo manual, propicia uma compactação considerável da camada superficial do solo, pelos pneus dos tratores e sobretudo dos caminhões. Chuvas intensas nessas condições dão origem às enxurradas (pouco carregadas de material em suspensão se os resíduos cobrem o solo) que podem localizadamente, destruir as bordas de terraço de absorção/infiltração e criar ravinas e posteriormente voçorocas.

Mesmo que as plantas de cana-de-açúcar não sejam queimadas e que os resíduos cubram a superficie, seria indicado principalmente para os solos de textura argilosa (como prevenção) uma subsolagem, com o intuito de melhorar a microporosidade do solo. Na realidade, o período no qual o solo permanece compactado parece ser muito curto, pois na maior parte dos locais observados pode-se perceber que o simples trabalho das máquinas no solo (uma ou duas passagens de arado ou grade, para revolver velhas raízes) já havia limitado os riscos de enxurradas durante o período crucial, no qual o solo está pouco coberto. 


\section{CONCLUSÕES}

A maior parte da área da bacia está sujeita a um risco baixo de erosão. As áreas com riscos de erosão mais acentuados estão localizados principalmente em duas regiões: ao redor do eixo de maior desenvolvimento urbano (entre as cidades de Piracicaba e Campinas) e próxima às nascentes dos rios que compõem a bacia. Na primeira região mencionada, o maior risco se deve, provavelmente, à exposição de solos de textura predominantemente arenosa às chuvas, especialmente sob o cultivo da cana-de-açúcar, que em seu estágio inicial de desenvolvimento, não oferece uma boa cobertura vegetal. As causas do risco de erosão elevado, na área próxima às nascentes, estão relacionadas à interação dos agentes: relevo acidentado, solos pouco profundos, pastagem mal manejada (algumas vezes degradadas) e pluviosidade concentrada.

Pode-se concluir que aplicação da EUPS através da utilização de técnicas de geoprocessamento é uma metodologia adequada e pode ser considerada como uma ferramenta importante para o diagnóstico e monitoramento de áreas de risco de erosão, uma vez que a verificação de campo indicou um valor aproximado de $80 \%$ de correspondência entre as estimativas dos riscos de erosão obtidas pelo mapeamento e pela observação de campo.

Pensando em possíveis cenários de reocupação das áreas, o método também foi suficientemente sensível para detectar as diferenças ocorridas. Supondo-se, uma situação em que houvesse a necessidade de ampliação das áreas cultivadas com cana-de-açúcar, 
utilizando-se as áreas ocupadas por pastagem, o método mostrou que os riscos de erosão ficaram claramente aumentados. Isso acarretaria evidentemente, um prejuízo ao ambiente, sobretudo na qualidade da água dos rios, devido à deposição de sedimentos. $\mathrm{O}$ cenário mais promissor é aquele onde as áreas de pastagem foram substituídas por vegetação nativa. Através dessa simulação, fica constatada a sensibilidade do método em relação às mudanças no uso e cobertura do solo.

Verificou-se no campo, que o risco potencial de erosão (que depende da agressividade das chuvas, do declive e da erodibilidade dos solos) é considerado de médio a alto. Mas as zonas mais críticas estão cobertas com vegetação florestal e os sedimentos que possam ser liberados podem ser captados em várias ocasiões. A cana de açúcar fornece uma boa cobertura do solo, exceto naquelas semanas do ano, nas quais se efetua o preparo do solo (gerando grandes torrões de terra) e a cada cinco anos, quando as áreas de cana são reformadas/replantadas, deixando o solo completamente exposto.

Entretanto, observou-se no campo, que, de maneira geral, o risco de erosão na bacia é baixo e as ravinas observadas são bem localizadas, informações que coincidem com aquelas geradas pelos mapas. A maior parte dos problemas de erosão na bacia são oriundos das águas das rodovias e estradas rurais (que são totalmente desnudas); das pastagens em declives superiores a $20 \%$ e de caminhos regularmente trilhados pelo gado; dos litossolos (saturação rápida do solo) em encostas côncavas e dos terraços de absorção/infiltração rompidos ou terraços de escoamento muito longos. 


\section{REFERÊNCIAS BIBLIOGRÁFICAS}

ALVES, D.S. Sistemas de informações geográficas. Geoprocessamento, v.1, n.1, p.6678, maio, 1990.

BACELLAR, A.A.A. Estudo da erosão na microbacia hidrográfica do ribeirão Cachoeirinha - município de Iracemápolis, utilizando um sistema de informação geográfica. Campinas: FEAGRI/UNICAMP, 1994. 30p. (Relatório técnico)

BALLESTER, M.V.R. Uso de sistemas de informações geográficas no estudo da paisagem da bacia do rio Piracicaba -São Paulo, Brasil. Piracicaba: FAPESP, 1996. 27p. (Projeto de Pesquisa enviado à FAPESP)

BALSTROEM, T. Mapping of erosion risk assessment in Denmark. In: ANNUAL ESRI USER CONFERENCE, 14., 1994. ESRI User Conference 94: Abstracts on CDROM, 1994.

BATJES, N.H.. Global assessment of land vulnerability to water erosion on a $1 / 2^{0}$ by $1 / 2^{0}$ grid. Land degradation \& development, v.7, n.4, p.353-365, 1996

BELLINAZZI JÚNIOR, R.; BERTOLINI, D.; LOMBARDI NETO, F. Ocorrência da erosão rural no Estado de São Paulo. In: SIMPÓSIO SOBRE O CONTROLE DA EROSÃO, 2., São Paulo, 1981. Anais. São Paulo: IBGE, 1981. p.117-137. 
BERGSMA, E. Rainfall erosion survey for conservation planning. ITC Journal, Enschede, v.2, p.116-174, 1983.

BERTONI, J.; LOMBARDI NETO, F. Conservação do solo. São Paulo: Icone, 1990. $335 p$.

BIGARELLA, J.J.; MAZUCHOWSKI, J.Z. Visão integrada da problemática da erosão. In: SIMPÓSIO NACIONAL DE CONTROLE DE EROSÃO, 3., Maringá, 1985. Anais. Maringá: ABGE. 1985. p.332.

BORGES, M.H.; PFEIFER, R.M.; DEMATTÊ, J.A.M. Evolução e mapeamento do uso da terra, através de imagens aerofotogramétricas e orbitais em Santa Bárbara D’Oeste (SP). Scientia Agricola, v.50, n.3, p.365-371, 1993.

BRADY, N.C. Natureza e propriedades dos solos. 7 ed. Trad. De A.B. N. Figueiredo Filho. Rio de Janeiro: Freitas Bastos, 1989. 898p.

BRASIL. Ministério da Agricultura. Centro Nacional de Ensino e Pesquisa Agronômicas. Comissão de Solos. Levantamento de reconhecimento de solos do Estado de São Paulo. Rio de Janeiro, 1960. 634p. (SNPA. Boletim, 12).

BRASIL. Ministério das Minas e Energia. Departamento Nacional da Produção Mineral. Projeto RADAMBRASIL: folha SF. 23 Rio de Janeiro e folha SF. 24 Vitória; geologia, geomorfologia, vegetação, uso potencial da terra. Rio de Janeiro, 1983. 780p. (Levantamento dos Recursos Naturais, 32).

BRITO, J.L.S.; LIMA, S.C.; SHIKI, S.; MOREIRA, M.R.. Uso do geoprocessamento na estimativa da perda de solos por erosão laminar em Iraí de Minas - MG. In: SIMPÓSIO BRASILEIRO DE SENSORIAMENTO REMOTO, 9., Santos, 1998. SBSR 98: trabalhos. São José dos Campos, 1998. 
BURROUGH, P.A. Principles of geographical information systems for land resources assessment. Monographs on soil and resources survey. Oxford. 1986, $193 p$.

CASTRO, A.G de. Técnicas de sensoriamento remoto e sistemas geográficos de informações no estudo integrado de bacias hidrográficas. São José dos Campos, 1992. 145p. Dissertação (Mestrado) - Instituto Nacional de Pesquisas Espaciais.

CHAVES, H.M.L.; SILVA, P.A; CARLOS, R.J.. Aplicação da USLE e SGI na predição da erosão atual e potencial a nível regional: o caso do Vale do São Francisco. In: CONGRESSO BRASILEIRO DE CIÊNCIA DO SOLO, 25., Viçosa, 1995. Anais, Viçosa, 1995. p.1961-1963.

COMPANHIA DE TECNOLOGIA DE SANEAMENTO AMBIENTAL - CETESB. Controle da poluição ambiental na bacia do rio Piracicaba. São Paulo: CETESB, 1991.

DE LIMA, E.R.V.; KUX, H.J.H.; SAUSEN, T.M. Sistema de informações geográficas e técnicas de sensoriamento remoto na elaboração de mapa de risco de erosão no sertão da Paraíba. Revista Brasileira de Ciências do Solo, v.16, p.257-263, 1992.

DEMERS, M.N. Fundamentals of geographic information systems. New York: John Wiley \& Sons, 1997. 486p.

DENARDIN, J.E. Erodibilidade do solo estimada por meio de parâmetros físicos e químicos. Piracicaba, 1990. Tese (Doutorado) - Escola Superior de Agricultura "Luiz de Queiroz", Universidade de São Paulo. 
DESMET, P.J.J.; GOVERS, G.. A GIS procedure for automatically calculating the USLE LS factor on topographically complex landscape units. Journal of Soil and Water Conservation, v. 51, n. 5, p.427-433, 1996.

DOBSON, J.E. Commentary: a conceptual framework for integrating remote sensing, GIS and geography. Photogr. Eng. and Remote Sensing, v.59, n. 10, p.1491-1496, 1993.

DONZELI, P. L.; VALÉRIO FILHO, M.; PINTO, S. A. F.; NOGUEIRA, F. P.; ROTTA, C. L.; LOMBARDI NETO, F. Técnicas de sensoriamento remoto aplicadas ao diagnóstico básico para planejamento e monitoramento de microbacias hidrográficas. In: Microbacia do Córrego São Joaquim (Município de Pirassununga, SP). Documentos IAC-29. Campinas, IAC, 1992. p.91-119.

FAO. Protect and produce: putting the pieces together. Roma, 1992. 36p

FELTRAN FILHO, A. contribuição à análise fluviométrica da bacia do rio Piracicaba. Rio Claro, 1982. 188p. Dissertação (Mestrado) - Instituto de Geociências e Ciências Exatas, Universidade Estadual Paulista.

FIORIO, P. R. Avaliação cronológica do uso da terra e seu impacto no ambiente da microbacia hidrográfica do córrego do Ceveiro da região de Piracicaba - SP. Piracicaba, 1998. 114 p. Dissertação (Mestrado) - Escola Superior de Agricultura "Luiz de Queiroz", Universidade de São Paulo.

FOSTER, G.R.; MOLDENHAUER, W.C.; WISCHMEIER, W.H. Transferability of US techonology for prediction and control of erosion in the tropics. In: SYMPOSIUM ON SOIL EROSION AND CONSEVATION IN THE TROPICS, 1., Fort Collins, 1979. Soil Erosion and Conservation in the Tropics, resumos.. Madison: ASA, 1985. p.135-149. 
FOURNIER, F. Conservacion de suelos. Madrid: Mundi Prensa, 1975. 256p.

FRASER, R. H; WARREN, M.V.; BARTEN, P.K.. Comparative evaluation of land cover data sources for erosion prediction. Water Resources Bulletin, v. 31, n.6, p.991-1000, 1995.

FUNDAÇÃO DO DESENVOLVIMENTO ADMINISTRATIVO - FUNDAP. Alternativas de gestão do meio ambiente na bacia do rio Piracicaba. São Paulo: FUNDAP, 1991. (Relatório Final)

GOMES, A.R.; MALDONADO, F.D. Análise de componentes principais em imagens multitemporais TM/Landsat como subsídio aos estudos de vulnerabilidade à perda de solo em ambiente semi-árido. In: SIMPÓSIO BRASILEIRO DE SENSORIAMENTO REMOTO, 9., Santos, 1998. SBSR 98: trabalhos. São José dos Campos, 1998.

GOODCHILD, M.F. The state of GIS for environmental problem-solving. In: GOODCHILD, M.F.; PARKS, B.O.; STEYAERT, L.T., (Ed.) Environmental modelling with GIS. New York: Oxford Unviversity Press, 1993. p.8-15.

GUANGWEI, C.. Land degradation approach: methodology and pratice. In: INTERNATIONAL CONFERENCE ON GEO-INFORMATION FOR SUSTAINABLE LAND MANAGEMENT. CD-ROM: papers. Enschede: p. 1- 10, 1997.

GUERRA, A.; ROIZEN, J.; SCHUELER, E. Fatores e classificação da erosão pluvial dos solos e seus impactos ambientais. In: SIMPÓSIO NACIONAL DE CONTROLE DA EROSÃO, 5., Bauru, 1995. Anais. São Paulo: IBGE, 1995. p. 447-450. 
GUPTILL, S.C. Evaluationg geographic information systems technology. Photor. Eng. and Rem. Sensing, v.55, n.1, p.1583-1587, 1989.

HAMLETT, J.M.; MILLER, D.A; DAY, R.L.; PETERSON, G.W.; BAUMER, G.M.; RUSSO, J. Statewide GIS-based ranking of watersheds for agricultural pollution prevention. Journal of Soil and Water Conservation, v.47, n.5, p.399-404, 1992.

HICKEY, R.; SMITH, A.; JANKOWSKI, P. Slope lenght calculations from a dem within ARC/Info grid. Comput., environ. and urban system, v.18, n. 5 p.365-380, 1994.

INSTITUTO BRASILEIRO DE GEOGRAFIA E ESTATÍSTICA - IBGE. Cartas do Brasil, 1983. Escala 1:50.000.

INSTITUTO DE PESQUISAS TECNOLÓGICAS DO ESTADO DE SÃO PAULO IPT. Orientações para o combate à erosão no Estado de São Paulo, bacia do Peixe-Paranapanema. São Paulo, 1986. (IPT - Relatório Técnico, 24.739)

INSTITUTO DE PESQUISAS TECNOLÓGICAS DO ESTADO DE SÃO PAULO IPT. Orientações para o combate à erosão no Estado de São Paulo, bacia do Médio Tietê. São Paulo. 1991. (IPT - Relatório Técnico, 29.004)

INSTITUTO DE PESQUISAS TECNOLÓGICAS DO ESTADO DE SÃO PAULO IPT. Plano de obras de contenção das erosões urbanas do município de Bauru, SP: $2^{a}$. fase. São Paulo, 1994. 52p. (TPT - Relatório, 32.207).

INSTITUTO GEOGRÁFICO E CARTOGRÁFICO DO ESTADO DE SÃO PAULO IGC. Carta de utilização da terra do Estado de São Paulo. Folhas de Campinas, Guaratinguetá e Santos. Escala de 1:250.000. São Paulo, 1980. 
INSTITUTO GEOGRÁFICO E CARTOGRÁFICO DO ESTADO DE SÃO PAULO IGC. Carta de utilização da terra do Estado de São Paulo. Folhas de Bauru e São Paulo. Escala de 1:250.000. São Paulo, 1981.

INSTITUTO NACIONAL DE PESQUISAS ESPACIAIS - INPE. Imagem de satélite Landsat-TM, bandas 1, 2, 3, 4, 5 e 7, escala digital, ano de 1993.

JÄGER, S. Modelling regional soil erosion susceptibility using the Universal Soil Loss Equation and GIS. In: RICKSON, R.J., (Ed.) Conservation Soil Resources European Perspectives. Cambridge: Silsoe College, Cranfield University, 1994, cap. 17, p. 161-177.

KERTZMAN, F. F.; RIBEIRO, F.C.; CANIL, K.; ALMEIDA, L.E.G.. Erosão no Estado de São Paulo: bacias hidrográficas críticas. In: SIMPÓSIO NACIONAL DE CONTROLE DA EROSÃO, 5., Bauru, 1995. Anais. São Paulo: IBGE, 1995. p.221224.

KRUSCHE, A.V.; CARVALHO F.P.; MORAES, J.M.; CAMARGO, P.B.; BALLESTER, M.V.R.; HORNINK, S.; MARTINELLI, L.A.; VICTORIA, R.L. Spatial and temporal water quality variability in the Piracicaba River basin, Brazil. Journal of the American Water Resources Association, v.33, n.5, p.1117-1123, 1997.

LAL, R. Soil erosion by wind and water: problems and prospects. In: LAL, R., (Ed.) Soil erosion research methods. Iowa: Soil and Water Conservation Society, 1988. p.1-6.

LAL, R. Soil Erosion Impact on Agronomic Productivity and Environment Quality. Plant Sciences, v.17, n.4, p.319-464, 1998. 
LAL, R. Erosion impact on soil quality in the tropics. In LAL, R. (Ed.) Soil Quality and Soil Erosion, 1999. p.285-305.

LE BISSONNAIS, Y. Aggregate stability and assessment of soilcrustability and erodibility. Theory and methodology.European Journal of Soil Science, v.47, n.4, p. 425-437, 1996.

LEPSCH, I.F., coord. Manual para levantamento utilitário do meio físico e classificação de terras no sistema de capacidade de uso. Campinas: SBCS, 1983. $175 p$.

LEVY, M. do C.T.C. Avaliação da sustentabilidade das terras de Piracicaba por comparação de cenários. Piracicaba, 1995. Dissertação (Mestrado) - Escola Superior de Agricultura "Luiz de Queiroz", Universidade de São Paulo.

LOMBARDI NETO, F., (Coord.) Microbacia do córrego São Joaquim - município de Pirassununga, SP. Campinas: Instituto Agronômico do Estado de São Paulo, 1992. 138 p.

LOMBARDI NETO, F; MOLDENHAUER, W.C. Erosividade da chuva: sua distribuição e relação com as perdas de solo em Campinas (SP). Bragantia, v.51, n.2, p.189-196, 1992.

MANTEL, S.; VAN ENGELEN, V.W.P. The impact of land degradation on food productivity: case studies of Uruguay, Argentina and Kenya. Wageningen: International Soil Refernce and Information Centre, 1997. 44p. (Maim report 97/01)

MERTES, L. Computational techniches for watershed analysis. Santa Barbara: Univerity of Califórnia, 654p. 1997. (Class notebook) 
MORAES, J.F.L. de; LOMBARDI NETO, F.; DONZELI, P.L. Avaliação do meio físico da microbacia do Córrego da Fortuna, Presidente Venceslau, para fins de planejamento agroambiental. In: CONGRESSO LATINO AMERICANO DE CIÊNCIA DO SOLO, 13., Águas de Lindóia, 1996. SoloSuelo 96: trabalhos. Piracicaba: SBCS/SLCS, 1996.

OLIVEIRA, A.M.S. Depósitos tectogênicos e assoreamento de resevatórios: exemplo do reservatório de Capivara, rio Paranapanema, SP/PR. São Paulo, 1994. 221p. Tese (Doutorado) - Faculdade de Filosofia, Letras e Ciências Humanas, Universidade de São Paulo.

PELLEGRINO, G.Q. Análise espaço-temporal de dados hidrológicos da bacia do rio Piracicaba. Piracicaba, 1995. 117p. Dissertação (Mestrado) - Escola Superior de Agricultura "Luiz de Queiroz", Universidade de São Paulo.

PELLETIER, R.E. Evaluating nonpoint pollution using remotely sensed data in soil erosion models. Journal of Soil and Water Conservation, v.40, n.4, p.332-335, 1985.

PETERSEN, G.W.; NIZEYIMANA, E.; EVANS, B.M. Applications of geographic information systems in soil degradation assessments. In: LAL, R.; BLUM, W. H.; VALENTINE, C.; STEWART, B.A. Methods for Assessment of Soil Degradation. Advances in Soil Science. New York: CRC Press, 1997. p.377-391.

PINTO, S.A.F. Sensoriamento remoto e integração dos dados aplicados no estudo de erosão dos solos: contribuição metodológica. São Paulo, 1991. Tese (Doutorado) Ciências/Geografia Física, Universidade de São Pailo. 
PRANDINI, F.L.; NAKAZAWA, V.A.. A erosão urbana: algumas considerações. In: SIMPÓSIO NACIONAL DE CONTROLE DA EROSÃO, 5., Bauru, 1995. Anais. São Paulo: IBGE, 1995. p.95.

PROJETO PIRACENA. "Banco de dados biogeoquímica". Outubro de 1997. (07/10/98). http//: www.cena.usp.br/piracena.

QUEIROZ NETO, J.P.; CHRISTOFOLETTI, A. Ação do escoamento superficial das águas pluviais na Serra de Santana, Estado de São Paulo. Boletim Paulista de Geografia, v.6, n.68, p.59-71, 1968.

RANIERI, S.B.L. Avaliação de métodos e escalas de trabalho para a determinação de risco de erosão em bacia hidrográfica utilizando sistema de informações geográficas. São Carlos, 1996, 128p. Dissertação (Mestrado) - Escola de Engenharia de São Carlos, Universidade de São Paulo.

ROOSE, E.; BLANCANEAUX, P.; DE FREITAS, P.L.. Un simple test de terrain pour évaluer la capacité d'infiltration et le comportement hydrodynamique des horizons pédologiques superficiels: méthode et exemples. Cahiers Orstom, série Pédologie, 28, p. 413-421, 1993.

ROOSE E. Introduction à la GCES, Bull. Pedol. Fao. Rome, 1994, 420p.

ROOSE, E.. Land husbandry: components and strategy. FAO Soils Bulletin, 70. 380p. 1996.

ROOSE, E. (Coord.) Spécial érosion. L'Ínstitut Français de Recherche Scientifique Pour le Développement en Coopération, n.56. 1998. 41p. 
SAIZ, C.del C.; VALÉRIO FILHO, M. Técnicas de geoprocessamento aplicadas ao levantamento e integração de dados do meio físico como subsídio ao planejamento conservacionista. In: CONGRESSO LATINO AMERICANO DE CIÊNCIA DO SOLO, 13., Águas de Lindóia, 1996. SoloSuelo 96: trabalhos. Piracicaba: SBCS/SLCS, 1996.

SÃO PAULO. Secretaria de Energia e Saneamento. Departamento de Águas e Energia Elétrica. Controle de erosão: bases conceituais e técnicas; diretrizes para o planejamento urbano e regional; orientações para o controle de boçorocas urbanas. São Paulo: DAEE/IPT, 1989. 92p.

SÃO PAULO. Conselho Estadual de Recursos Hídricos. Plano estadual de recursos hídricos: primeiro plano do Estado de São Paulo. São Paulo: DAEE, 1991a.

SÃO PAULO. Secretaria de Energia e Saneamento. Departamento de Águas e Energia Elétrica. Centro Tecnológico de hidráulica e Recursos Hídricos. Inventário dos postos hidrométricos operados pelo DAEE. São Paulo: CTH, 1991b, 127p.

SÃO PAULO. Consórcio Intermunicipal das bacias dos rios Piracicaba e Capivari. Programa de investimentos para a recuperação e proteção das bacias dos rios Piracicaba e Capivari. São Paulo, 1992.

SÃO PAULO. Secretaria do Meio Ambiente. Bacia do rio Piracicaba. Estabelecimento de metas ambientais e reenquadramento dos corpos d'água. São Paulo, 1994.

SHENG, T.C.; BARRET, R.E.; MITCHELL, T.R.. Using geographic information systems for watershed classification and rating in developing countries. Journal of Soil and Water Conservation, v.52, n.2, p.84-97. 1997 
STAR, J.; ESTES, J. Geographic information system: an introduction. New Jersey: Prentice Hall, 1990. 303p.

VENTURA, S.J.; CHRISMAN, N.R.; CONNORS, K.; GURDA, R.F.; MARTIN, R.W. A land information system for soil erosion control planning. Journal of Soil and Water Conservation, v.43, n.3, p.230-233, 1988.

WILD, A. Soils and the environment: an introduction. Cambridge: University Press, 1993. $287 \mathrm{p}$.

WISCHMEIER, W.H.; JOHNSON, C.B.; CROSS, B.W. A soil erodibility monograph for farmland and construction sites. Journal of Soil and Water Conservation, v.26, n. 5, p. 189-193, 1971.

WISCHMEIER, W.H.; SMITH, D.D. Predicting rainfall erosion losses: a guide to conservation planning. Washington: Department of Agriculture, 1978. 47p. (USDA. Agriculture Handbook, 537). 